\title{
Effects of Urbanization on Stream Ecosystems in the Willamette River Basin and Surrounding Areas, Oregon and Washington
}

Chapter D of

Effects of Urbanization on Stream Ecosystems in Six Metropolitan Areas of the United States

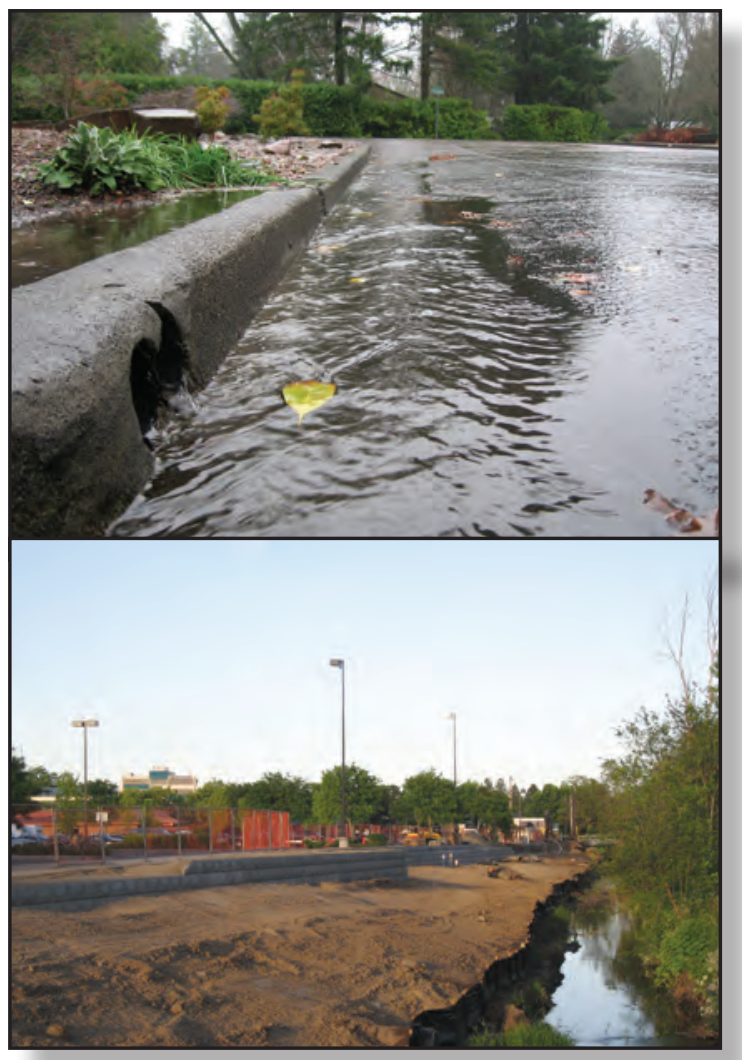

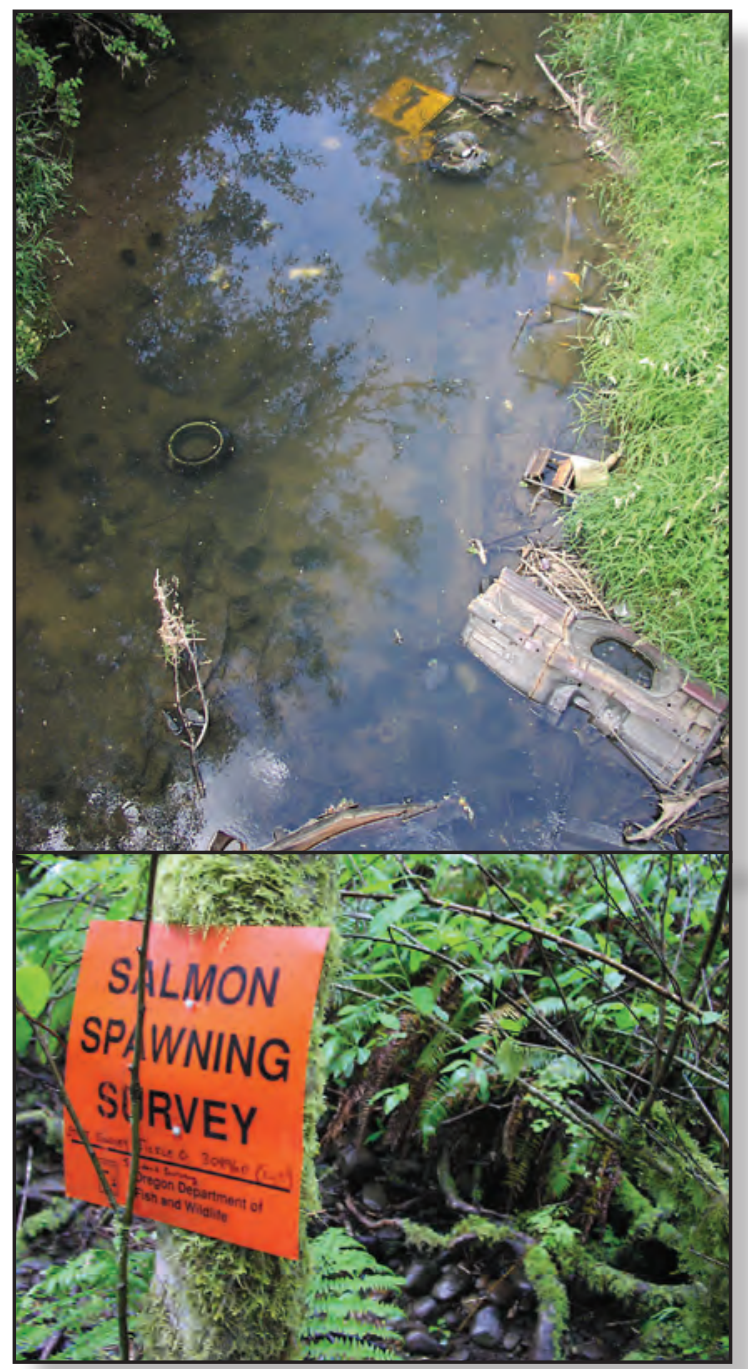

Scientific Investigations Report 2006-5101-D 
Front Cover - Starting lower left corner then clockwise:

Oregon Department of Fish and Wildlife salmon spawning sign at Tickle Creek near Boring, Oregon. (photo by Andy Arnsberg, hydrologic technician, Portland Bureau of Environmental Services, Portland, Oregon, 2004.)

Rainfall runoff along gutter of an impervious street surface, Beaverton. (photo by Hank Johnson, hydrologist, USGS, Portland, Oregon, 2007.)

Urban debris in Johnson Creek at Circle Avenue, Oregon. (photo by Andy Arnsberg, hydrologic technician, Portland Bureau of Environmental Services, Portland, Oregon, 2004.)

Sediment barrier for urban development along Beaverton Creek. (photo by Hank Johnson, hydrologist, USGS, Portland, Oregon, 2008.)

Back Cover - Starting lower left clockwise:

Andy Arnsberg collecting water quality sample at N.F. Deep Creek at Barton, Oregon. (photo by Kurt Carpenter, biologist, USGS, Portland, Oregon, 2004.) Ian Wigger collecting transducer data at Rock Creek near Vancouver, Washington. (photo by Mike Sarantou, hydrologic technician, USGS, Portland, Oregon, 2004.)

Fanno Creek near Beaverton, Oregon, during a winter high flow event. (photo by Hank Johnson, hydrologist, USGS, Portland, Oregon, 2007.)

Claggett Creek at Keizer, Oregon during summer low flow. (photo by Andy Arnsberg, hydrologic technician, Portland Bureau of Environmental Services,

Portland, Oregon, 2004.) 


\section{Effects of Urbanization on Stream Ecosystems in the Willamette River Basin and Surrounding Area, Oregon and Washington}

By Ian R. Waite, Steven Sobieszczyk, Kurt D. Carpenter, Andrew J. Arnsberg, Henry M. Johnson, Curt A. Hughes, Michael J. Sarantou, and Frank A. Rinella

National Water-Quality Assessment Program

Chapter D of

Effects of Urbanization on Stream Ecosystems in

Six Metropolitan Areas of the United States

Scientific Investigations Report 2006-5101-D 


\section{U.S. Department of the Interior DIRK KEMPTHORNE, Secretary}

\section{U.S. Geological Survey \\ Mark D. Myers, Director}

\section{U.S. Geological Survey, Reston, Virginia: 2008}

For product and ordering information:

World Wide Web: http://www.usgs.gov/pubprod

Telephone: 1-888-ASK-USGS

For more information on the USGS--the Federal source for science about the Earth, its natural and living resources, natural hazards, and the environment:

World Wide Web: http://www.usgs.gov

Telephone: 1-888-ASK-USGS

Any use of trade, product, or firm names is for descriptive purposes only and does not imply endorsement by the U.S. Government.

Although this report is in the public domain, permission must be secured from the individual copyright owners to reproduce any copyrighted materials contained within this report.

Suggested citation:

Waite, I.R., Sobieszczyk, Steven, Carpenter, K.D., Arnsberg, A.J., Johnson, H.M., Hughes, C.A., Sarantou, M.J., and Rinella, F.A., 2008, Effects of urbanization on stream ecosystems in the Willamette River basin and surrounding area, Oregon and Washington: U.S. Geological Survey Scientific Investigations Report 2006-5101-D, 62 p. 


\section{Foreword}

The U.S. Geological Survey (USGS) is committed to providing the Nation with accurate and timely scientific information that helps enhance and protect the overall quality of life and that facilitates effective management of water, biological, energy, and mineral resources (http://www.usgs. gov//). Information on the quality of the Nation's water resources is critical to assuring the long-term availability of water that is safe for drinking and recreation and suitable for industry, irrigation, and habitat for fish and wildlife. Population growth and increasing demands for multiple water uses make water availability, now measured in terms of quantity and quality, even more essential to the long-term sustainability of our communities and ecosystems.

The USGS implemented the National Water-Quality Assessment (NAWQA) Program in 1991 to support national, regional, and local information needs and decisions related to water-quality management and policy (http://water.usgs.gov/nawqa). Shaped by and coordinated with ongoing efforts of other Federal, State, and local agencies, the NAWQA Program is designed to answer: What is the condition of our Nation's streams and ground-water? How are the conditions changing over time? How do natural features and human activities affect the quality of streams and ground-water, and where are those effects most pronounced? By combining information on water-chemistry, physical characteristics, stream habitat, and aquatic life, the NAWQA Program aims to provide science-based insights for current and emerging water issues and priorities.

From 1991 to 2001, the NAWQA Program completed interdisciplinary assessments in 51 of the Nation's major river basins and aquifer systems, referred to as Study Units (http://water.usgs.gov/nawqa/ studyu.html). Baseline conditions were established for comparison to future assessments, and longterm monitoring was initiated in many of the basins. During the next decade, 42 of the 51 Study Units will be reassessed so that 10 years of comparable monitoring data will be available to determine trends at many of the Nation's streams and aquifers. The next 10 years of study also will fill in critical gaps in characterizing water-quality conditions, enhance understanding of factors that affect water quality, and establish links between sources of contaminants, the transport of those contaminants through the hydrologic system, and the potential effects of contaminants on humans and aquatic ecosystems.

The USGS aims to disseminate credible, timely, and relevant science information to inform practical and effective water-resource management and strategies that protect and restore water quality. We hope this NAWQA publication will provide you with insights and information to meet your needs, and will foster increased citizen awareness and involvement in the protection and restoration of our Nation's waters.

The USGS recognizes that a national assessment by a single program cannot address all water-resource issues of interest. External coordination at all levels is critical for a fully integrated understanding of watersheds and for cost-effective management, regulation, and conservation of our Nation's water resources. The NAWQA Program, therefore, depends on advice and information from other agenciesFederal, State, interstate, Tribal, and local—as well as nongovernmental organizations, industry, academia, and other stakeholder groups. Your assistance and suggestions are greatly appreciated. 
This page intentionally left blank. 


\section{Contents}

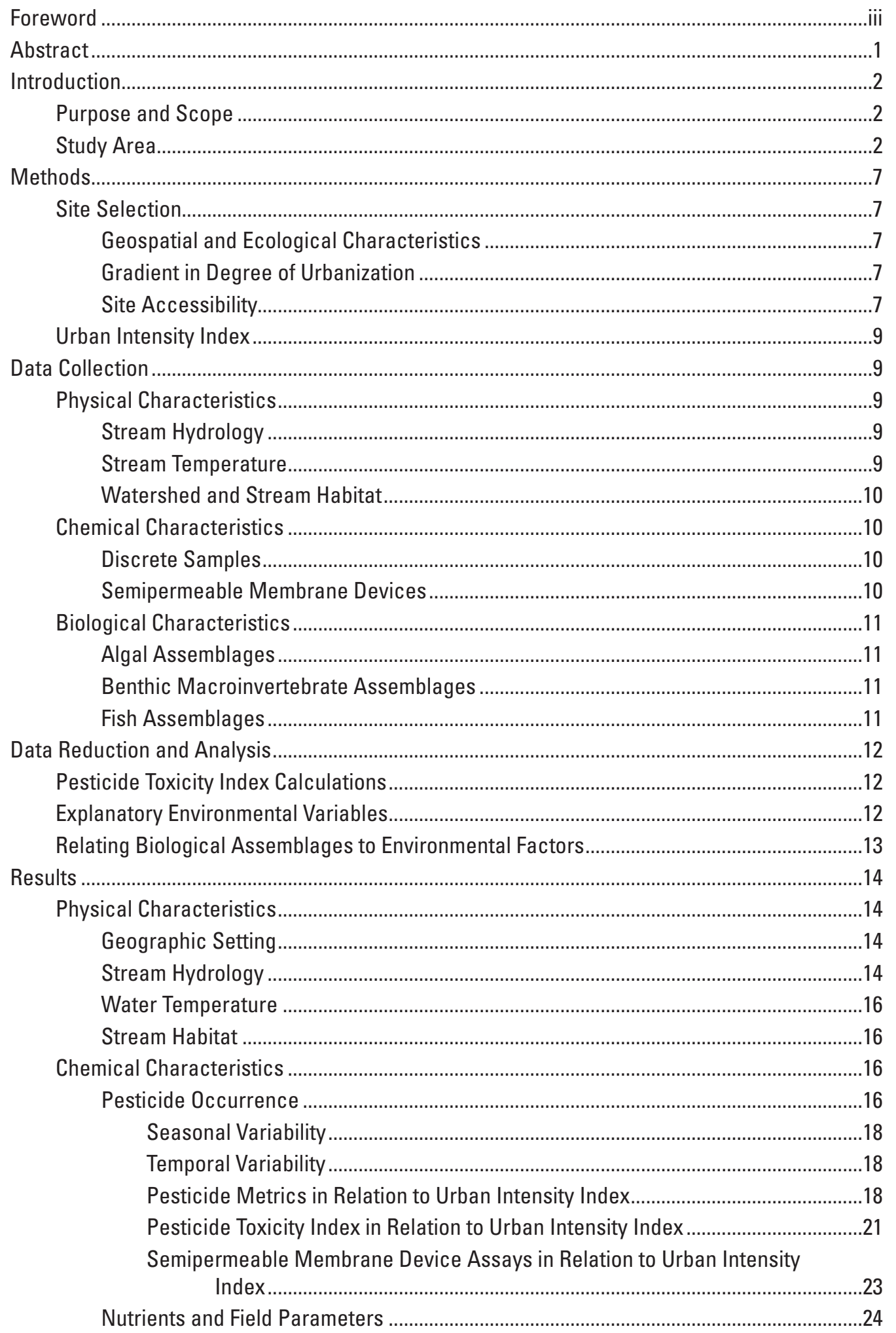




\title{
Contents-Continued
}

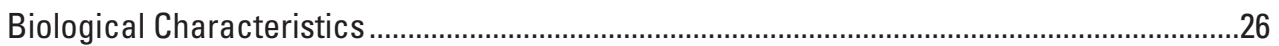

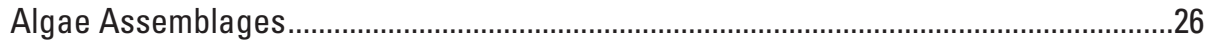 \\ Response in Algal Biomass to Urban Intensity Index..........................................27 \\ Multivariate Analysis of Diatom Assemblages ......................................................30 \\ Response in Algal Metrics to Urban Intensity Index and Select Environmental

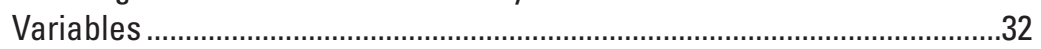 \\ Benthic Macroinvertebrate Assemblages ......................................................................33 \\ Benthic Macroinvertebrate Metrics in Relation to Urban Intensity Index .............34 \\ Multivariate Analysis of Benthic Macroinvertebrate Assemblages.......................37

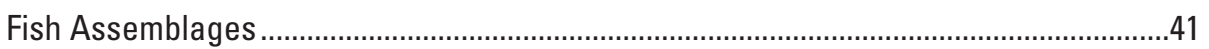 \\ Fish Metrics in Relation to Urban Intensity Index ................................................4 \\ Multivariate Analysis of Fish Assemblages ...........................................................4

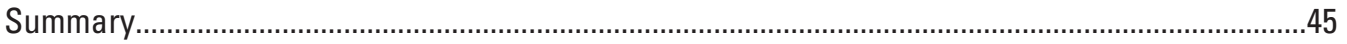

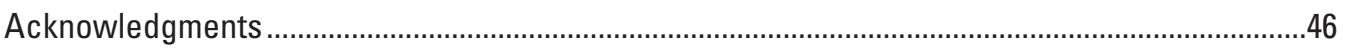

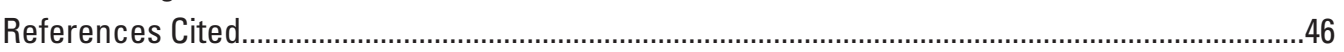

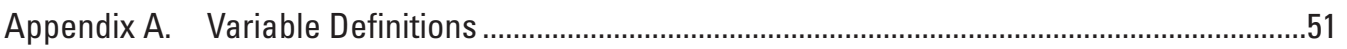

\section{Figures}

Figure 1. Map showing location of the Willamette River basin and surrounding area, Oregon and Washington

Figure 2. Map showing level III ecoregions of the Willamette River basin and surrounding area, Oregon and Washington

Figure 3. Map showing national land cover data, Willamette River basin and surrounding area, Oregon and Washington, 2001

Figure 4. Map showing candidate and final watersheds selected for the urban gradient study, Willamette River basin and surrounding area, Oregon and Washington $\quad \ldots \quad 8$

Figure 5. Graph showing relation between urban intensity index (UII) and number of falling hydrologic events greater than or equal to 9 times the median, Willamette River basin and surrounding area, Oregon and Washington

Figure 6. Graph showing percentage of riffle habitat in relation to summer dissolved oxygen concentrations, Willamette River basin and surrounding area, Oregon and Washington

Figure 7. Boxplots showing pesticide concentrations and detection frequency for all stream samples, Willamette River basin and surrounding area, Oregon and Washington

Figure 8. Graph showing urban intensity index (UII) and percentage of agricultural land for all 28 sites, Willamette River basin and surrounding area, Oregon and Washington 21

Figure 9. Graph showing total pesticide concentration in relation to urban intensity index (UII) for all 28 sites, Willamette River basin and surrounding area, Oregon and Washington 


\section{Figures-Continued}

Figure 10. Graph showing total insecticide concentration in relation to urban intensity index (UII) for all 28 sites, Willamette River basin and surrounding area, Oregon and Washington

Figure 11. Graph showing relations between Pesticide Toxicity Index (PTI) and $(A)$ urban intensity index (UII) and (B) road density (ROADDEN), Willamette River basin and surrounding area, Oregon and Washington

Figure 12. Graph showing relation between the urban intensity index (UII) and semipermeable membrane device results for the $(A)$ toxic equivalent index (TEO) and (B) pyrene index

Figure 13. Graph showing relations between average total nitrogen concentrations and $(A)$ urban intensity index (UII) and $(B)$ percentage of urban plus agricultural land, Willamette River basin and surrounding area, Oregon and Washington

Figure 14. Graph showing relation between the urban intensity index (UII) and (A) chlorophyll- $a$ and $(B)$ ash-free dry mass, Willamette River basin and surrounding area, Oregon and Washington

Figure 15. Graph showing relations between ash-free dry mass and $(A)$ nutrient index and $(B)$ concentrations of dissolved organic carbon, and $(C)$ dissolved organic carbon and concentrations of dissolved oxygen, Willamette River basin and surrounding area, Oregon and Washington

Figure 16. Graph showing relations between urban intensity index (UII) and (A) percentage of algal taxa requiring high levels of dissolved oxygen, and $(B)$ relative density of eutrophic algae, Willamette River basin and surrounding area, Oregon and Washington

Figure 17. Graph showing relation between urban intensity index (UII) and number of benthic macroinvertebrate taxa (richness) in the Ephemeroptera, Plecoptera, and Trichoptera orders (EPT), Willamette River basin and surrounding area, Oregon and Washington

Figure 18. Graph showing benthic macroinvertebrate nonmetric dimensional scaling ordination axis 1 scores in relation to $(A)$ urban intensity index (UII), (B) summer dissolved oxygen concentrations, $(C)$ percentage of flat and low elevation land in watershed and $(D)$ and toxic equivalents from semipermeable membrane devices, Willamette River basin and surrounding area, Oregon and Washington

Figure 19. Graph showing relation between urban intensity index (UII) and percent dominance by single fish species at all 28 sites (highest relative abundance), Willamette River basin and surrounding area, Oregon and Washington

Figure 20. Graph showing relation between fish assemblages (nonmetric dimensional scaling first axis ordination scores) and (A) urban intensity index (UII), $(B)$ toxic equivalents (TEO) from semipermeable membrane devices, $(C)$ summer dissolved oxygen (DO) concentrations and (D) the number of falling hydrologic events (PeriodF5), Willamette River basin and surrounding area, Oregon and Washington

Figure 21. Graph showing relation between midday summer dissolved oxygen (D0) concentrations and percentage of salmonids, Willamette River basin and surrounding area, Oregon and Washington 


\section{Tables}

Table 1. Land cover and other watershed characteristics for 28 streams sampled during the urbanization gradient study, Willamette River basin and surrounding area, Oregon and Washington

Table 2. Correlations of urban indicator metrics and environmental setting metrics, Willamette River basin and surrounding area, Oregon and Washington

Table 3. Spearman's rank correlations between urban indicator and water-chemistry metrics and select environmental variables, Willamette River basin and surrounding area, Oregon and Washington

Table 4. Number of pesticide detections at each site by pesticide type for spring and summer 2004, Willamette River basin and surrounding area, Oregon and Washington

Table 5. Summary statistics of pesticide concentrations collected during spring and summer 2004, Willamette River basin and surrounding area, Oregon and Washington

Table 6. Spearman's rank correlation coefficients (rho values) between urban indicator and water-chemistry variables, Willamette River basin and surrounding area, Oregon and Washington

Table 7. Most common algal taxa from the five major Divisions identified in Richest Targeted Habitat samples, Willamette River basin and surrounding area, Oregon and Washington

Table 8. Dominant algal taxon (by cell density) at each site, dominant diatom taxon, and diatom water-quality indicator classification, Willamette River basin and surrounding area, Oregon and Washington

Table 9. Spearman's rank correlation coefficients (rho values) between diatom algal metrics and the urban intensity index and select environmental variables, Willamette River basin and surrounding area, Oregon and Washington

Table 10. Number of benthic macroinvertebrate taxa and maximum abundance per insect order or noninsect group, Willamette River basin and surrounding area, Oregon and Washington

Table 11. Commonly observed benthic macroinvertebrate taxa and tolerance values, Willamette River basin and surrounding area, Oregon and Washington

Table 12. Single dominant benthic macroinvertebrate taxon at each site, taxon name, U.S. Environmental Protection Agency tolerance value, Ephemeroptera, Plecoptera, and Trichoptera richness, and richness percentage per site, Willamette River basin and surrounding area, Oregon and Washington

Table 13. Comparison of average benthic invertebrate abundance and richness metrics for high- and low-urban streams, Willamette River basin and surrounding area, Oregon and Washington

Table 14. Correlation between selected benthic macroinvertebrate metrics and environmental variables, Willamette River basin and surrounding area, Oregon and Washington

Table 15. Fish species richness, total abundance, percentages of dominance (single species), salmonids, and nonnative fish for 28 sites, Willamette River basin and surrounding area, Oregon and Washington

Table 16. Correlations of fish metrics and nonmetric dimensional scaling axis 1 ordination scores with environmental variables, Willamette River basin and surrounding area, Oregon and Washington 


\section{Conversion Factors, Datums, and Abbreviations and Acronyms}

Conversion Factors

\begin{tabular}{lcl}
\hline Multiply & By & To obtain \\
\hline centimeter $(\mathrm{cm})$ & 0.3937 & inch (in.) \\
gram $(\mathrm{g})$ & 0.03527 & ounce, avoirdupois (oz) \\
kilometer $(\mathrm{km})$ & 0.6214 & mile (mi) \\
liter $(\mathrm{L})$ & 33.82 & ounce, fluid (fl. oz) \\
liter $(\mathrm{L})$ & 0.2642 & gallon (gal) \\
meter $(\mathrm{m})$ & 3.281 & foot (ft) \\
millimeter $(\mathrm{mm})$ & 0.03937 & inch (in.) \\
square centimeter $\left(\mathrm{cm}^{2}\right)$ & 0.001076 & square foot $\left(\mathrm{ft}^{2}\right)$ \\
square kilometer $\left(\mathrm{km}^{2}\right)$ & 0.3861 & square mile $\left(\mathrm{mi}^{2}\right)$ \\
square meter $\left(\mathrm{m}^{2}\right)$ & 0.0002471 & acre \\
square meter $\left(\mathrm{m}^{2}\right)$ & 10.76 & square foot $\left(\mathrm{ft}^{2}\right)$ \\
square mile $\left(\mathrm{mi}^{2}\right)$ & 2.590 & square kilometer $\left(\mathrm{km}^{2}\right)$ \\
\hline
\end{tabular}

Temperature in degrees Celsius $\left({ }^{\circ} \mathrm{C}\right)$ may be converted to degrees Fahrenheit $\left({ }^{\circ} \mathrm{F}\right)$ as follows:

$$
{ }^{\circ} \mathrm{F}=\left(1.8 x^{\circ} \mathrm{C}\right)+32 \text {. }
$$

Specific conductance is given in microsiemens per centimeter at 25 degrees Celsius $(\mu \mathrm{S} / \mathrm{cm}$ at $\left.25^{\circ} \mathrm{C}\right)$.

Concentrations of chemical constituents in water are given either in milligrams per liter ( $\mathrm{mg} / \mathrm{L}$ ) or micrograms per liter $(\mu \mathrm{g} / \mathrm{L})$.

Datums

Vertical coordinate information is North American Vertical Datum of 1988 (NAVD 88).

Horizontal coordinate information is Universal Transverse Mercator (UTM), Zone 10, North American Datum of 1927 (NAD 27).

Elevation, as used in this report, refers to distance above the vertical datum. 


\section{Conversion Factors, Datums, and Abbreviations and Acronyms - Continued}

Abbreviations and Acronyms

\begin{tabular}{|c|c|}
\hline $\begin{array}{l}\text { Abbreviations and } \\
\text { Acronyms }\end{array}$ & Meaning \\
\hline ADAS & Algal Data Analysis System \\
\hline ADPS & Automated Data Processing System \\
\hline AFDM & ash-free dry mass \\
\hline AhR & aryl hydrocarbon receptor \\
\hline BOD & biological oxygen demand \\
\hline $\mathrm{CVO}$ & Cascade Volcano Observatory \\
\hline DIN & dissolved inorganic nitrogen \\
\hline DO & dissolved oxygen \\
\hline DOC & dissolved organic carbon \\
\hline EPT & Ephemeroptera (mayflies), Plecoptera (stoneflies), Trichoptera (caddesflies) \\
\hline EUSE & Effects of Urbanization on Stream Ecosystems \\
\hline $\mathrm{H} 2 \mathrm{~S}$ & hydrogen sulfide \\
\hline IDAS & Invertebrate Data Analysis System \\
\hline NAWQA & National Water-Quality Assessment \\
\hline NIST & National Institute of Standards and Technology \\
\hline nMDS & nonmetric dimensional scaling \\
\hline NWIS & National Water Information System \\
\hline NWQL & National Water-Quality Laboratory \\
\hline PAH & polycyclic aromatic hydrocarbons \\
\hline PCA & principle component analysis \\
\hline PCB & polychlorinated biphenyls \\
\hline PTI & Pesticide Toxicity Index \\
\hline QA & quality assurance \\
\hline QC & quality control \\
\hline $\mathrm{QMH}$ & qualitative multihabitat \\
\hline RGS & reporter gene system \\
\hline ROADDEN & road density \\
\hline RTH & richest target habitat \\
\hline SAS & Statistical Analysis Software \\
\hline SPMD & semipermeable membrane device \\
\hline SRP & soluble reactive phosphorus \\
\hline TEQ & toxic equivalent \\
\hline $\mathrm{TN}$ & total nitrogen \\
\hline $\mathrm{TP}$ & total phosphorus \\
\hline UII & Urban intensity index \\
\hline USEPA & U.S. Environmental Protection Agency \\
\hline USGS & U.S. Geological Survey \\
\hline
\end{tabular}




\title{
Effects of Urbanization on Stream Ecosystems in the Willamette River Basin and Surrounding Area, Oregon and Washington
}

\author{
By lan R. Waite, Steven Sobieszczyk, Kurt D. Carpenter, Andrew J. Arnsberg, Henry M. Johnson, \\ Curt A. Hughes, Michael J. Sarantou, and Frank A. Rinella
}

\section{Abstract}

This report describes the effects of urbanization on physical, chemical, and biological characteristics of stream ecosystems in 28 watersheds along a gradient of urbanization in the Willamette River basin and surrounding area, Oregon and Washington, from 2003 through 2005. The study that generated the report is one of several urban-effects studies completed nationally by the U.S. Geological Survey National Water-Quality Assessment Program. Watersheds were selected to minimize natural variability caused by factors such as geology, elevation, and climate, and to maximize coverage of different stages of urban development among watersheds. Because land use or population density alone often are not a complete measure of urbanization, a combination of land use, land cover, infrastructure, and socioeconomic variables were integrated into a multimetric urban intensity index (UII) to represent the degree of urban development in each watershed. Physical characteristics studied include stream hydrology, stream temperature, and habitat; chemical characteristics studied include sulfate, chloride, nutrients, pesticides, dissolved and particulate organic and inorganic carbon, and suspended sediment; and biological characteristics studied include algal, macroinvertebrate, and fish assemblages. Semipermeable membrane devices, passive samplers that concentrate trace levels of hydrophobic organic contaminants such as polycyclic aromatic hydrocarbons and polychlorinated biphenyls, also were used. The objectives of the study were to (1) examine physical, chemical, and biological responses along the gradient of urbanization and (2) determine the major physical, chemical, and landscape variables affecting the structure of aquatic communities.

Common effects documented in the literature of urbanization on instream physical, chemical, and biological characteristics, such as increased contaminants, increased streamflow flashiness, increased concentrations of chemicals, and changes in aquatic community structure toward a more tolerant community associated with organically enriched conditions, generally were observed in this study. The strongest correlations to the UII and to many of the algal, macroinvertebrate, and fish assemblage metrics and community ordination involved water-chemistry metrics including the total pesticide concentration, toxic equivalents (extract assay from semipermeable membrane devices), and dissolved oxygen. Hydrologic variability metrics, such as flashiness, that normally are considered to be one of the main processes of urban disturbance had a strong association to the algal and fish assemblages in this study; however, the hydrologic variables for macroinvertebrates were secondary to the water-chemistry metrics mentioned above. Generally, the high urban intensity sites had high abundances of eutrophic and lower dissolved oxygen-indicating diatoms, high abundances of noninsects and tolerant insects, and high abundances of nonnative fish species. On the other hand, the low urban intensity sites had higher abundances of pollution sensitive diatoms, larger numbers of the sensitive macroinvertebrate EPT taxa (Ephemeroptera, Plecoptera and Trichoptera Orders), and fish assemblages with higher abundances of sensitive salmonids. The percent salmonid and macroinvertebrate EPT richness metrics plotted against the UII indicated a possible threshold response at about 25 on the UII, which is equivalent to an impervious surface value of about 5 percent. However, due to the added agricultural land use at sites within the 25 to 60 UII range, this possible threshold probably is not solely due to urbanization, but a combination of urban and agricultural land use. The effects of agricultural and urban land use could not be distinguished from each other, yet combined they provide a good assessment of overall watershed disturbance. 


\section{Introduction}

Research has shown that stream ecosystems are increasingly degraded by urban development and human population growth (Booth and Jackson, 1997, Paul and Meyer, 2001; Walsh and others, 2005; Tate and others, 2005). The growth of urban areas changes landscapes and increases stresses to freshwater systems by adversely altering water-quality, habitat, biodiversity, and ecosystem processes (McDonnell and Pickett, 1990; Sala and others, 2000; Paul and Meyer, 2001; Brown and others, 2005; Sprague and others, 2006). Urban growth, or urbanization, is defined as the development of rural, agricultural, or forested land into urban land, such as buildings and roads. Urbanization may be further defined by incorporating population density estimates, percentages of urban land use classification from remote sensing data (Brown and others, 2005; Tate and others, 2005), or percentage of impervious surface cover (Arnold and Gibbons, 1996). Regardless of how urbanization is characterized, it directly changes the physical habitat and stream hydrology of a river system (Sinokrot and Stefan, 1993; LeBlanc and others, 1997). For example, encroachment of urban land into riparian areas decreases canopy cover, allowing more solar radiation to heat streams (Waite and Carpenter, 2000; Jacobson and others, 2001; Sprague and others, 2006). The expansion of urban land also introduces more industrial and human waste to rivers, which combines with more urban and agricultural pesticide applications that deteriorate water quality in streams. Additionally, urbanization brings increased development and more impervious surfaces.

Impervious surfaces, such as roads, parking lots, and rooftops, increase surface runoff volumes and reduce the amount of water that infiltrates into the soil and ground water. As a result, the excess runoff modifies stream hydrology and channel morphology causing the degradation of aquatic habitats (Winterbourne and Townsend, 1991), the increase in sedimentation rates (Waite and Carpenter, 2000), and a greater fluctuation in frequency and magnitude of stormflows.

To investigate the effect of multiple urban stressors on stream ecosystems, the U.S. Geological Survey (USGS) National Water-Quality Assessment (NAWQA) Effects of Urbanization on Stream Ecosystems (EUSE) study examined the effects of varying degrees of urbanization among various watersheds in the Willamette River basin and surrounding area. The approach integrated multiple parameters, such as socioeconomic variables, population statistics, and land use metrics, into a single index measurement of urbanization intensity (Cuffney and others, 2000; Tate and others, 2005), and was based on a common design and sample collection technique (McMahon and Cuffney, 2000). Using this multimetric indicator of urban intensity, 28 watersheds in the study area were selected with increasing degrees of urbanization (table 1). The urban land use gradient ranged from minimal urban development to highly developed land, while limiting differences in natural features and local disturbances. The gradient was used to assess the effects of urbanization on stream water chemistry, habitat, and biological conditions (Walsh and others, 2001; Fitzpatrick and others, 2004; Sprague and others, 2006).

\section{Purpose and Scope}

This report describes the physical (stream hydrology, water temperature, and stream habitat), chemical (nutrients and pesticides), and biological (algae, macroinvertebrate, and fish assemblages) characteristics of stream ecosystems in 28 watersheds along a gradient of urbanization in the Willamette River basin and surrounding area of Oregon and southwestern Washington from 2003 through 2005. Watersheds were selected to minimize natural variability between sites due to watershed size, elevation, and climate, and to maximize coverage of different degrees of urban development. The objectives of the study were to (1) examine physical, chemical, and biological responses along a gradient of urbanization and (2) determine the major physical, chemical, and landscape variables associated with aquatic communities.

\section{Study Area}

The Willamette River basin and surrounding area includes $35,000 \mathrm{~km}^{2}$ in northwestern Oregon and southwestern Washington (fig. 1). Although the Willamette River basin is in Oregon, the study area was extended into Washington because of similar socioeconomic, climatic, ecologic, and topographic settings. For example, $1,000 \mathrm{~km}^{2}$ of the Willamette ValleyLevel III ecoregion, as defined by Omernik (1987) extends across the Columbia River into Washington (fig. 2). An ecoregion-unlike a watershed, which delineates an area of convergent drainage_-denotes an area of shared natural characteristics, such as soil types, elevation, and climate. The Willamette Valley ecoregion contains a mixture of rolling prairies, mixed forests, and extensive lowland valley wetlands.

Land cover in the basin (fig. 3) is predominately forest (66 percent), with moderate agriculture ( 29 percent) and minimal urban (3.5 percent) and surface water (1.5 percent) (U.S. Geological Survey, 2005). The valley plains and foothills primarily are used for cultivated crops, pasture, and grasslands, although minimally developed areas, such as Dundee, Oregon, to highly developed urban areas, such as Portland, Oregon, also are in the valley. Fertile soils and a temperate climate 
Table 1. Land cover and other watershed characteristics for 28 streams sampled during the urbanization gradient study, Willamette River basin and surrounding area, Oregon and Washington.

[See figure 4 for site locations. Sites are sorted by urban intensity index (UII). Shading represents low, medium, high, and very high UII scores. Abbreviations: km², square kilometer; USGS, U.S. Geological Survey; SW, southwest; OR, Oregon, WA, Washington]

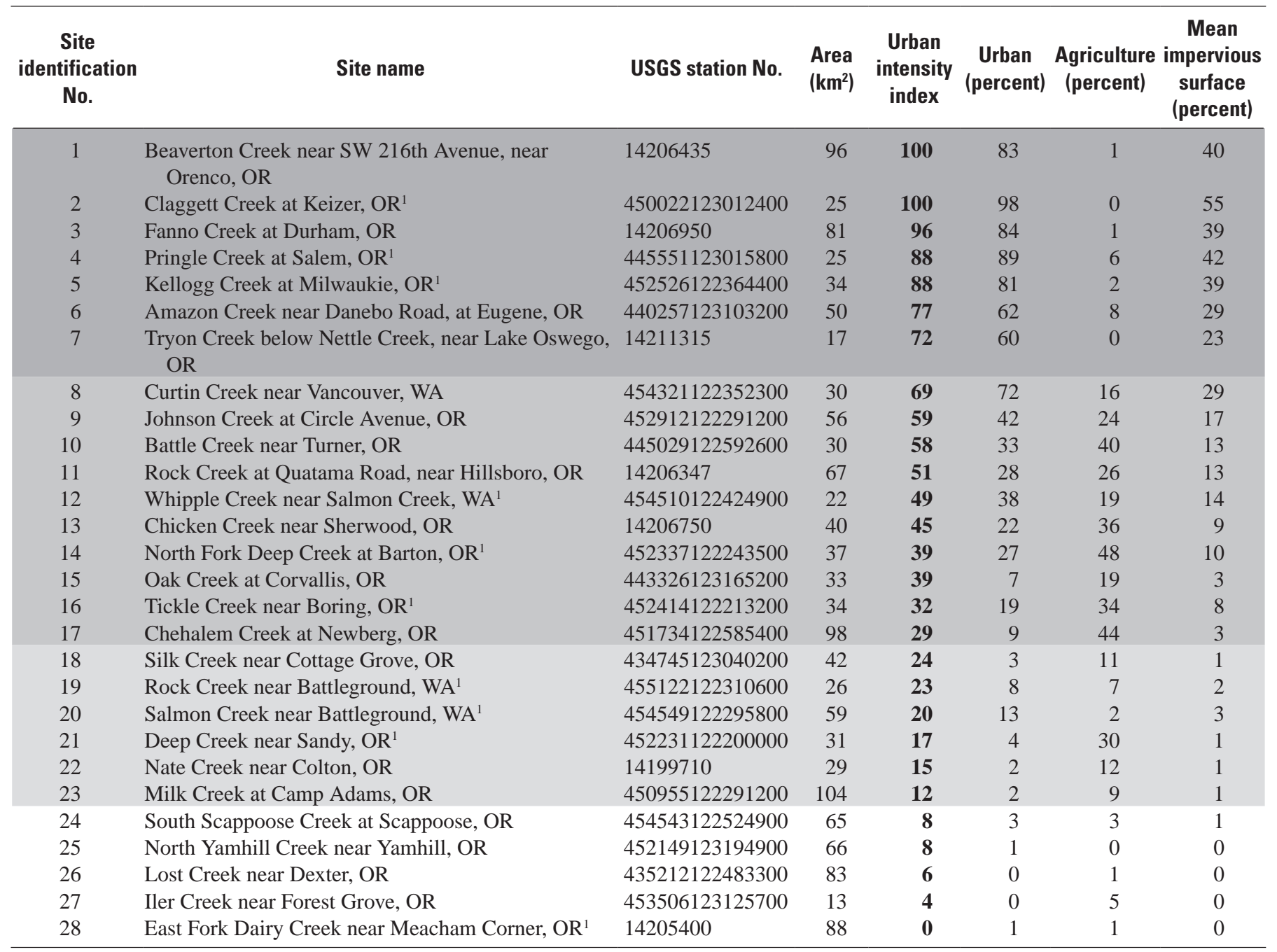

${ }^{1}$ High frequency sampling sites, which spanned the full range of the UII, were used to determine whether the degree of urbanization affected the seasonality of water chemistry.

make the Willamette Valley a thriving agricultural region (Thorson and others, 2003). Land use in the forested Coastal Range and Cascades is a combination of timber harvesting, recreation, and development. Centered on the confluence of the Columbia and Willamette Rivers, Portland is the most populous city in Oregon, with 539,000 people in city limits and nearly 3 million people in the Portland/Salem/Vancouver metropolitan area (U.S. Census Bureau, 2000). The population in the metropolitan area increased almost 30 percent from 1990 to 2000, with some suburban populations increasing more than 80 percent during the same period (U.S. Census Bureau, 2000).
With temperate, dry summers and cool, wet winters, the Willamette River basin and surrounding area is characteristic of Pacific Northwest climate. About 90 percent of the annual precipitation occurs during October through May (Uhrich and Wentz, 1999), falling as rain in the valley and snow in the mountains. The drainage network in the Willamette Valley combines natural dendritic tributaries, complex networks of canals in agricultural areas, and sewer piping in cities. Dams and reservoirs regulate most large rivers, such as the McKenzie, Santiam, and Willamette Rivers, which supply drinking water, power generation, and irrigation to different parts of the region. 


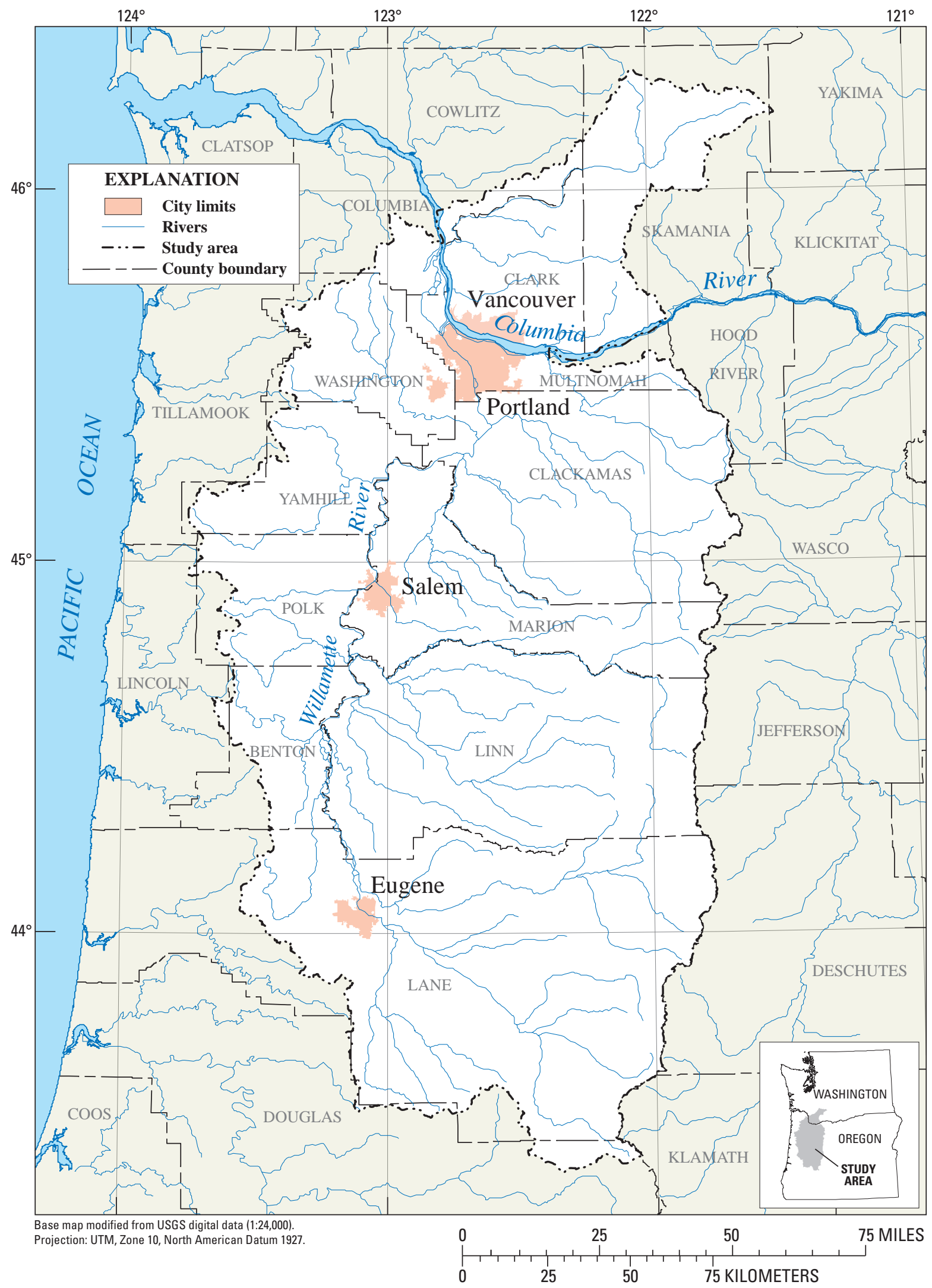

Figure 1. Location of the Willamette River basin and surrounding area, Oregon and Washington. 


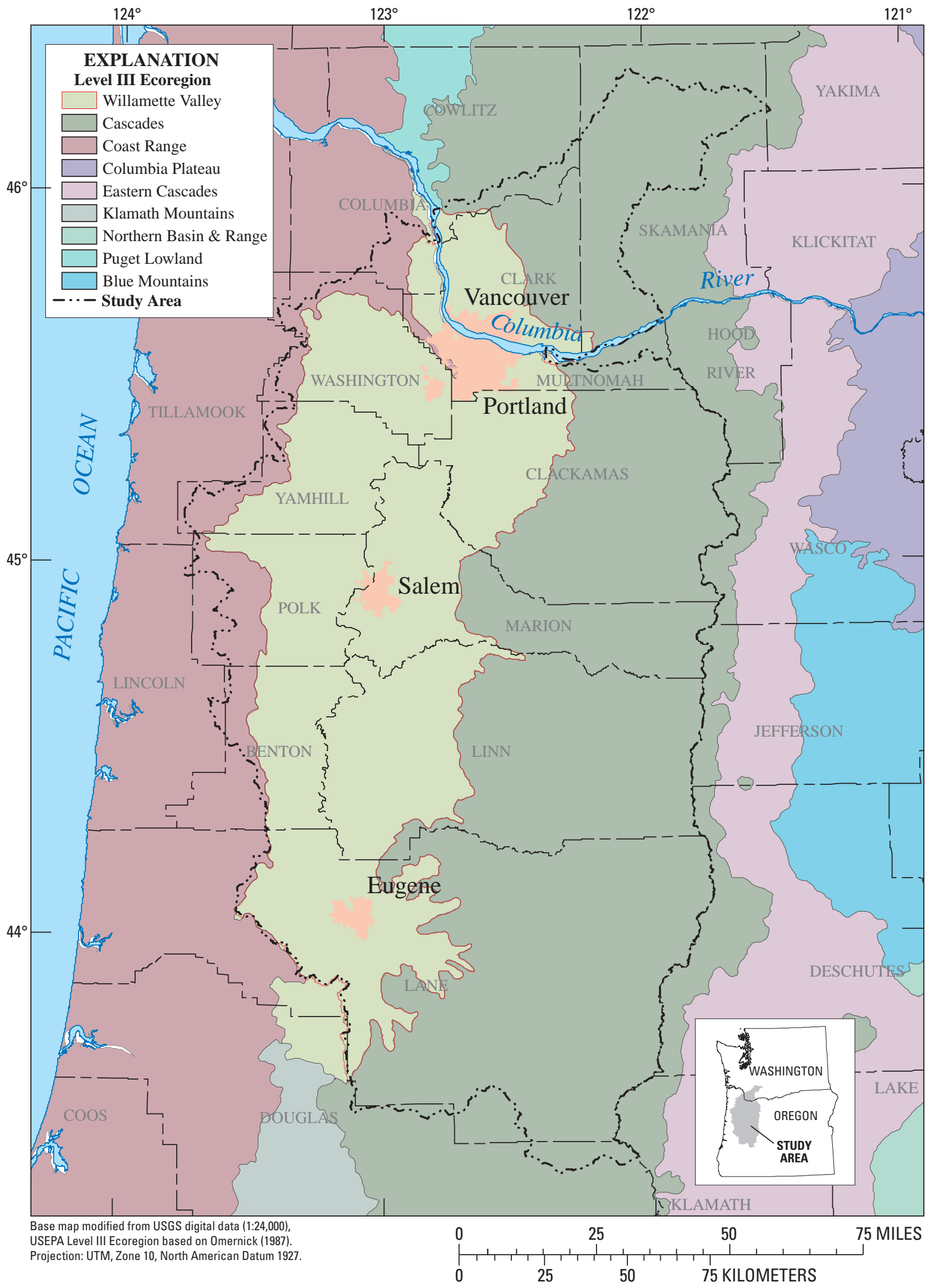

Figure 2. Level III ecoregions of the Willamette River basin and surrounding area, Oregon and Washington. 


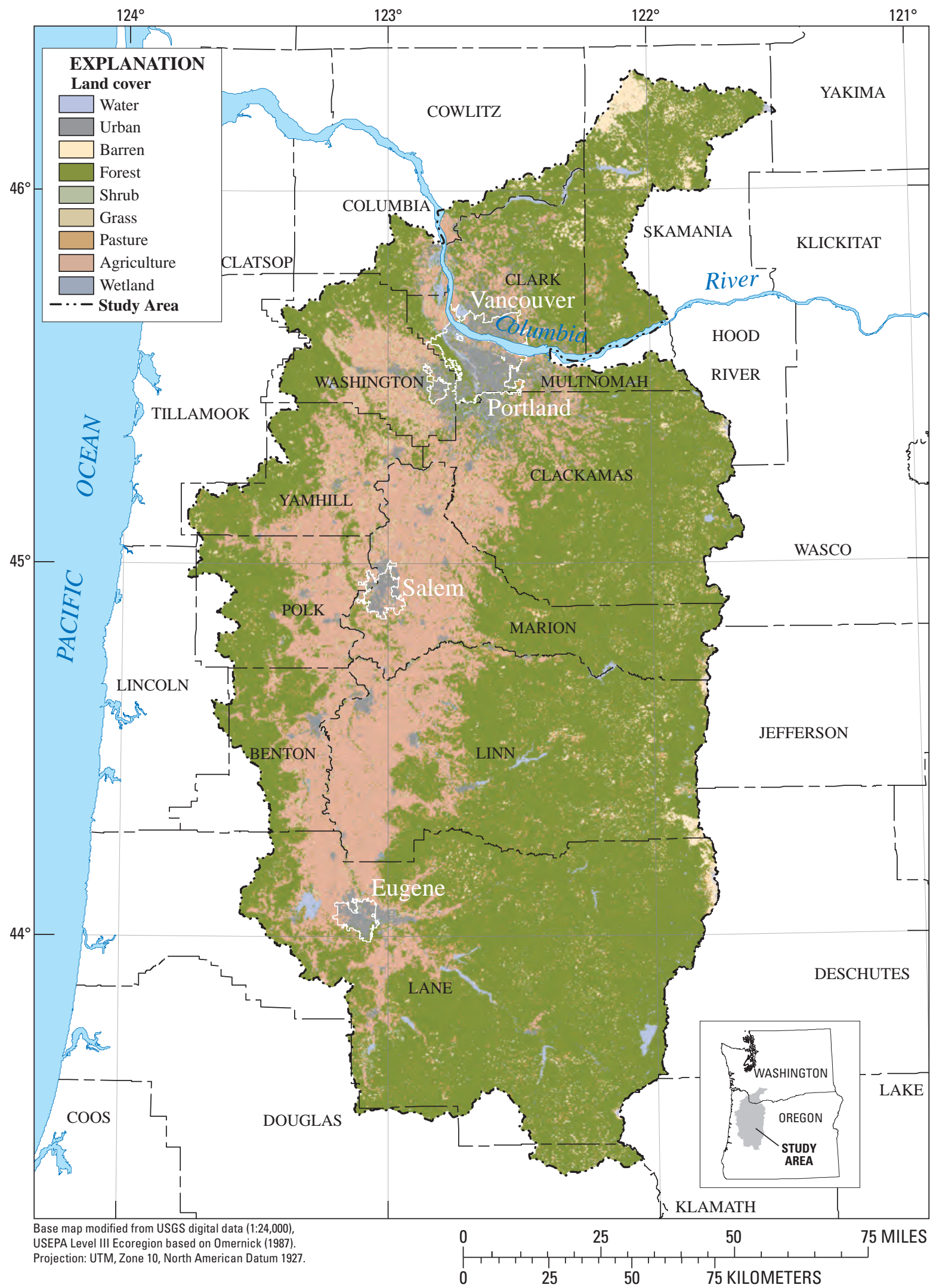

Figure 3. National land cover data, Willamette River basin and surrounding area, Oregon and Washington, 2001 (U.S. Geological Survey, 2005). 


\section{Methods}

Methods used during this study followed guidelines established for the National EUSE Program (Cuffney and others, 2000; McMahon and Cuffney, 2000; Tate and others, 2005). Site selection started with an initial 206 "candidate" streams and was eventually refined to 28 "final" streams. Data collection began in November 2003 and continued through March 2005, with the 28 final streams sampled for physical habitat, water chemistry, and aquatic biology. The final streams, and their associated watersheds, represented varying degrees of urbanization, yet shared similar geospatial and socioeconomic characteristics. During the study, 96 water-quality samples were collected and stream habitat was evaluated at each site. In addition, the biological community (algae, benthic macroinvertebrates, and fish) in each stream was sampled during low-flow conditions. Stream stage and water temperature were monitored in each stream from March through November 2004. Semipermeable membrane devices were installed at each location for about one month.

\section{Site Selection}

Streams selected for this study represented a full gradient of urbanization, and met the predefined geospatial and ecological characteristics developed for the National EUSE Program defined below.

\section{Geospatial and Ecological Characteristics}

To limit natural variability between watersheds, certain geospatial and ecological constraints were required. The two primary site selection constraints were "watershed size" and "percent coverage in the Willamette Valley-Level III Ecoregion (Omernik, 1987)". Watersheds could cover no less than $10 \mathrm{~km}^{2}$ and not exceed $130 \mathrm{~km}^{2}$. Additionally, all watersheds included a minimum of 20 percent of the Willamette Valley ecoregion. With these guidelines, site selection and watershed processing proceeded using Geographic Information Systems (GIS) and the USGS National Elevation Dataset (30-m resolution NED). An initial 206 candidate sites were identified and respective watersheds were delineated (fig. 4). Several GIS datasets were processed against the candidate watersheds, producing an assortment of land cover variables for each site. The GIS datasets included layers of socioeconomic (census variables), climatic (precipitation), ecologic (ecoregion), topographic (slope), hydrologic (hydrologic landscape regions), infrastructural (census road variables), and soil characteristics (erosion potential), which were calculated for (1) the entire basin, (2) the proximate segment of the upstream area, and (3) the adjacent riparian area (appendix A, table A1). For more detailed descriptions of techniques, conversions, and guidelines, as well as a complete list of geospatial variables and their descriptions, refer to Sprague and others (2006) and Falcone and others (2007).

\section{Gradient in Degree of Urbanization}

The main objective of this study was to examine the effect of different degrees of urbanization on stream ecosystems. Rather than investigate long-term temporal changes in one system, this study monitored a large number of sites at progressively higher levels of urbanization in a short timeframe. Theoretically, the relation of multiple sites at increasing degrees of urbanization should mimic similar development of one site over progressive years of increasing urbanization (Sprague and others, 2006). Therefore, selecting watersheds that represented a range in urbanization from minimum development to maximum development was paramount.

Classifying urbanization was more complicated than basing it solely on urban land use. For this study, watershed and riparian land cover, infrastructural, and demographic variables were integrated into a "candidate" urbanization intensity index (UII) (McMahon and Cuffney, 2000).

This UII was calculated from data for all 206-candidate watersheds. Seventeen GIS variables with at least a 0.5 Spearman's correlation to population density and that were not correlated above 0.5 with watershed size were included in the calculation. After the UII was generated, 70 of the 206 watersheds were selected for reconnaissance.

\section{Site Accessibility}

Each of the 70 remaining candidate sites were visited after their watersheds were delineated, characterized, and ranked with a UII. Field reconnaissance was used to verify GIS results and to evaluate accessibility and safety restrictions. Some sites were relocated upstream or downstream of the original location to obtain reaches with cobble or riffle substrate, or to avoid culverts or other undesirable obstacles. Some sites were excluded because the stream was ephemeral, watershed conditions were impossible to survey, or landowners would not permit access. Whenever possible, sites were selected to provide an even distribution along the UII.

Of the remaining candidate sites, a prerequisite 30 final sites were selected throughout the Willamette River basin and surrounding area. Initially, all 30 watersheds met the required geospatial and ecological characteristics. However, after adjustments for accessibility were incorporated into the drainage delineation, two sites did not fulfill the 20 percent coverage of the Level III ecoregion requirement-South Scappoose Creek in Oregon (6 percent) and Rock Creek in 


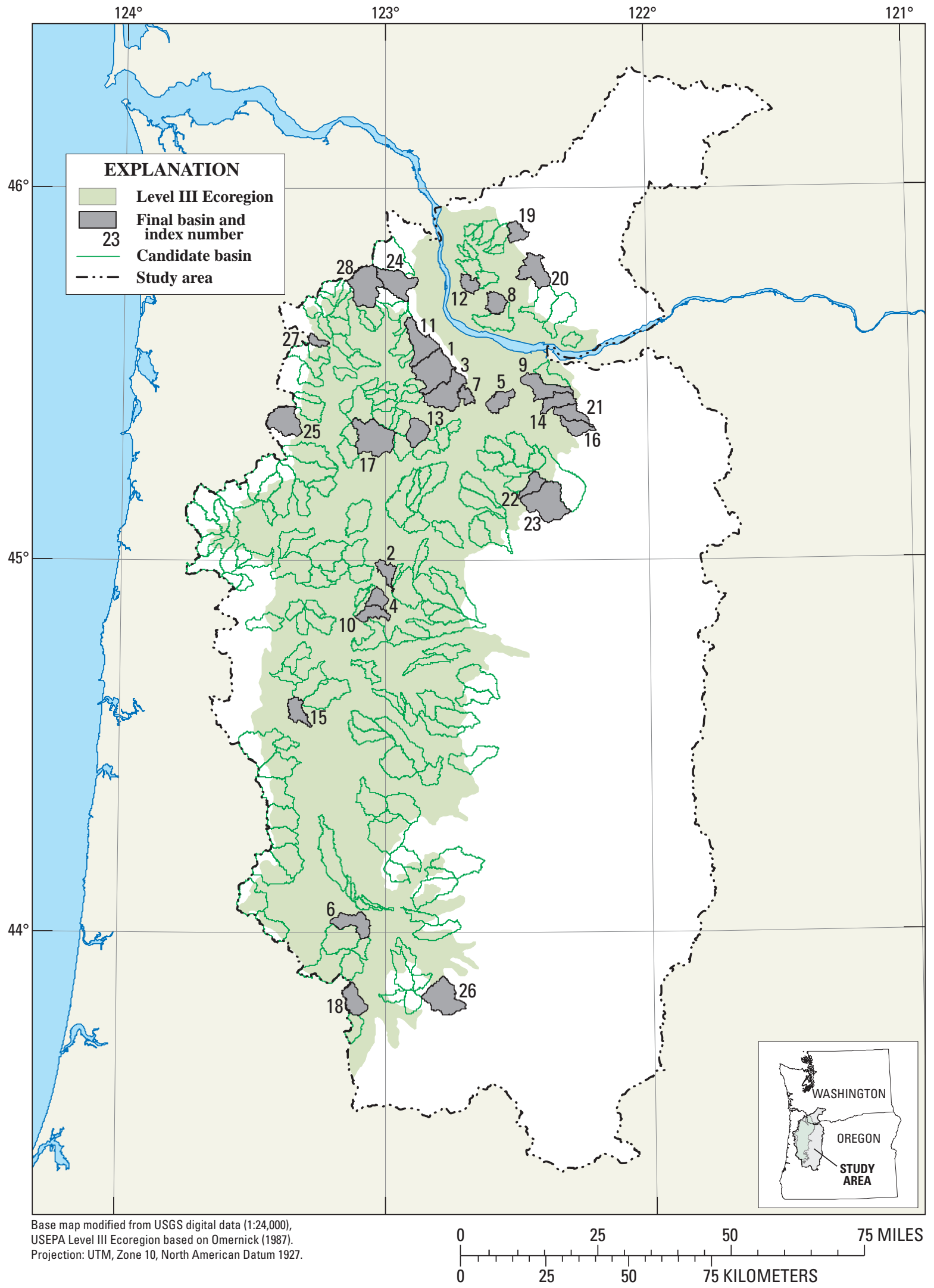

Figure 4. Candidate and final watersheds selected for the urban gradient study, Willamette River basin and surrounding area, Oregon and Washington. 
Washington (17 percent). The sites remained in the study after analysis of land cover, topographic, and hydrologic characteristics revealed that the watersheds shared similar characteristics with the other 28 sites and were necessary to fill vacancies in the urbanization gradient. Two other sites were eventually eliminated late in the study because conditions were not favorable for biological sampling in summer after water chemistry samples had been collected the previous winter. The final 28 sites and their basic watershed characteristics are listed in table 1.

\section{Urban Intensity Index}

A "final" UII was generated and applied to the 28 final sites based on the procedure developed by McMahon and Cuffney (2000). To calculate the final UII, a select group of 24 input GIS variables (table A2) were normalized to watershed area and then sorted by ascending variable percentage. The sorted values then were ranked on a scale of 0 to 100 . Variables that correlated with population density (according to a criterion of a Spearman's rank correlation of greater or equal to 0.70) and remained uncorrelated with watershed area (absolute value of Spearman's correlation less than or equal to 0.50 ) were used as inputs for the UII. For each site, all ranked GIS variables that met these constraints were averaged to produce a raw UII. The averaged raw values then were scaled from 0 to 100 . The resulting value represented the final urban intensity index value for each site. The final UII differed from the candidate UII because fewer sites were factored into the analysis, different GIS variables were incorporated into the UII calculation, and a higher Spearman's rank correlation was used (increased from 0.50 from 0.70 ).

\section{Data Collection}

\section{Physical Characteristics}

\section{Stream Hydrology}

Stevens-Greenspan Model PS310 pressure transducers, each with an internal data logger, were used to measure stream-stage fluctuation during the study (Greenspan Technology, 2006). Transducers were placed instream in pools or runs to ensure consistent response of hydrologic stage and to minimize the potential for dewatering. The transducer model was not vented to the atmosphere; therefore, changes in recorded pressure reflected changes in stream level and atmospheric pressure. Data were corrected for fluctuations in atmospheric pressure using hourly barometric pressure data from nearby airports because continuous barometric pressure records were not available at the study sites. The stage data from the transducers had a precision of $\pm 0.036 \mathrm{~m}$, which did not meet USGS requirements for stage data precision $( \pm 0.003 \mathrm{~m})$ (Sauer, 2002); however, it was deemed acceptable for the purposes of this study.

For logistical reasons, the pressure-transducer deployment periods varied among the sampling sites, with the most complete record obtained between March and November 2004. This 9-month period included a number of "typical" spring and autumn rain events, and provided adequate data to characterize the hydrologic variability among sites. Hydrologic variables calculated from the stage data included more than 35 hydrologic variables. These variables included measures of stage variability (regularity in streamflow), estimates of streamflow magnitude (amount of water moving past a given point per unit of time), stream flashiness (how quickly streamflow changes from one magnitude to another), duration (length of time associated with specific streamflow conditions), and frequency (how often streamflows greater than or less than a certain magnitude recur). Calculations were based on equations outlined in McMahon and others (2003) using SAS version 8 (Delwiche and Slaughter, 1998).

\section{Stream Temperature}

Stevens-Greenspan Model PS310 pressure transducers also monitored continuous water temperature data (30-minute intervals) during the study. Twenty percent of the transducers were tested for accuracy (within $\pm 0.01^{\circ} \mathrm{C}$, verified by comparing readings in a temperature bath with a traceable National Institute of Standards and Technology [NIS] thermometer prior to field deployment). Temperature data were stored in the Automated Data Processing System (ADAPS), a part of the National Water Information System (NWIS) (U.S. Geological Survey, 2003). Summary statistics for various water temperature measures included daily minimum, maximum, mean, range, and standard deviation, which were calculated for each stream using hourly data.

Occasionally, short periods of temperature record were lost due to transducer failure or dewatering, such as when stream levels dropped during low flow in late summer. Temperature data for the missing intervals were reconstructed using an extraction-correlation technique, which used the 30-minute data to extract daily mean values from March through November 2004 data. Sites then were correlated with each other. Linear regressions based on these correlations were used to estimate temperature values for days without a daily mean value. At sites with missing data, an average of the regressions was used to estimate missing values. 


\section{Watershed and Stream Habitat}

Watershed-level characterization of habitat provided information on the upstream geologic, climatic, hydrologic, morphologic, and biologic influences at a site. Watershedlevel habitat variables defined in this study included drainage area, drainage density, watershed length, mean watershed elevation, drainage shape, watershed relief, drainage texture, and cumulative perennial stream length. Other watershed-level information included land cover, surficial geology, soil, and riparian variables. Segment-level characterization of habitat provided information on finer scale influences in the relatively homogenous segment stream length. Actual segment length varies among streams depending on the distance between significant tributaries and/or point source inputs (Fitzpatrick and others, 1998). Segment-level variables determined in this study included sinuosity, slope segment length, and channel gradient. Watershed-level and segment-level characteristics were derived by GIS.

Reach-level characterization based on site visits was the principal means for describing local-scale influence within a segment (Fitzpatrick and others, 1998). Reach length was determined by multiplying the mean wetted channel width by 20 to ensure that all habitat types (pools, riffles, and runs), were represented within the reach. Reach-scale habitat data were collected during low-flow conditions in July and August 2004. Stream depth, width, bed substrate, habitat cover, bank morphology, canopy closure, stream velocity, and bank vegetation were measured at 11 or 12 equally spaced transects along each reach (mesoscale characterization). At one siteCurtin Creek-only nine transects were completed due to channel reach constraints. In addition, point velocity, substrate, and depth were measured where richest targeted habitat algae and benthic macroinvertebrate samples were collected (microscale characterization). A complete list of habitat variables used in this study is given in the appendix (tables A3 and A4). Detailed information on methods of habitat data collection and variables is available in Fitzpatrick and others (1998).

GIS variables, additional to those originally used in site selection and UII genesis, were gathered for analytical purposes. Hydrologic variables describing stream segment, riparian buffer, and road/stream intersection were examined, as well as associated dams, reservoirs, and waterway diversions. In addition, the program FRAGSTATS (McGarigal and others, 2002) was run for each final watershed to evaluate spatial land use patterns. FRAGSTATS variables quantified the degree of fragmentation, such as size, configuration, and connectivity, of urban and nonurban areas in a watershed (Sprague and others, 2006). As Alberti and Marzluff (2004) noted, this disruption of continuous land can affect ecosystem health by limiting or interrupting the natural movement of organisms. All additional GIS variables are available in Sprague and others (2006).

\section{Chemical Characteristics}

\section{Discrete Samples}

Water samples for chemical analysis were collected from all 28 sites twice during the study. Samples were collected from all sites in May 2004 (spring sampling) and in late August or early September 2004 (summer sampling) to bracket the biological sampling during July through September 2004. Water-chemistry conditions during these months were more likely to have a more direct effect on the biological communities in the streams than conditions earlier in the study. To document the seasonal variability in water chemistry, 10 of the 28 sites were sampled 4 additional times: November 2003, and January, March, and June 2004. These 10 "high frequency" sampling sites spanned the full range of the UII to determine whether the degree of urbanization affected the seasonality of water chemistry (table 1 ).

Sulfate, chloride, nutrients, pesticides, dissolved and particulate organic and inorganic carbon, and suspended sediment samples were collected at all sites (table A7). Field measurements of water temperature, dissolved oxygen (DO), $\mathrm{pH}$, specific conductance, and streamflow also were made during sampling. Samples were collected using standard protocols as outlined in the USGS National Field Manual (U.S. Geological Survey, variously dated). Nutrient and pesticide samples were analyzed at the USGS National Water-Quality Laboratory (NWQL) in Lakewood, Colorado, using methods developed by Fishman (1993) and Zaugg and others (1995). Suspended-sediment samples were analyzed at the USGS Cascade Volcano Observatory (CVO) sediment laboratory in Vancouver, Washington. Quality-control samples, including field blanks, replicates, and laboratory spikes were collected throughout the study and analyzed at the NWQL and CVO. About 10 percent of the total number of field samples was collected for quality assurance. All qualitycontrol, or quality-assurance, samples analyzed indicated that sample collection, processing, or laboratory analysis were acceptable.

\section{Semipermeable Membrane Devices}

Semipermeable membrane devices (SPMDs) are passive sampling cartridges that were deployed in each stream to sample and concentrate hydrophobic organic contaminants from the water (Huckins and others, 1993; Bryant and others, 2007). In this study, SPMDs were designed to mimic the fatty tissues of fish, and used to indicate the potential for bioaccumulation of polychlorinated dioxins and furans, polycyclic aromatic hydrocarbons (PAHs), polychlorinated biphenyls (PCBs), and organochlorine and pyrethroid insecticides. 
SPMDs were deployed in each of the 28 streams for about 4 weeks beginning in July 2004. At the end of the deployment period, they were removed and sent to multiple locations for analysis. Contaminant residues were recovered and separated at Environmental Sampling Technologies in St. Joseph, Missouri, as described in Huckins and others (1990). An ultraviolet fluorescence scan to quantify total PAHs (Johnson and others, 2004) and a Microtox ${ }^{\circledR}$ bioassay (Johnson, 1998) was run at the USGS Columbia Environmental Research Center in Columbia, Missouri. U.S. Army Corp of Engineers environmental laboratory in Vicksburg, Mississippi, ran an additional assay, the P450 RGS test that screens for aryl hydrocarbon receptor (AhR) type compounds that include PCBs, PAHs, dioxins, and furans (Murk and others, 1996).

Because SPMDs integrate chemical conditions over time and, sometimes, during variable flow conditions, they provide a more complete representation of chemical exposure than periodically collecting water samples (Huckins and others, 1993). SPMDs also eliminated the problem of determining chemical exposure in aquatic organism tissue by eliminating concern whether organisms metabolized compounds or if organisms migrated from exposure sources. Limitations of the SPMDs include:

1. The inner dialysis tubing (dialysate) was permeable only to nonionic compounds; and

2. The accumulation rates may have been affected by the physicochemical properties of individual nonionic compounds, variations in water temperature, flow velocity, and biofouling on the exterior membrane surface (Huckins and others, 1993) and the exposure duration.

All final data used in analysis were blank corrected/time normalized according to procedures outlined by Bryant and others (2007) to address these limitations and allow for better comparability of data among sites.

\section{Biological Characteristics}

Algal, benthic macroinvertebrate and fish assemblage samples were collected once during the study period in each of the 28 streams following protocols described in Moulton and others (2002). Algal and benthic macroinvertebrate samples were collected during September and October 2004, respectively, and fish communities were sampled in July and August 2004.

\section{Algal Assemblages}

Quantitative algal samples were collected at each site from riffles at the richest targeted habitat (RTH) using methods described in Moulton and others (2002). RTH algal samples were collected from 5 to 15 representative rocks per site and combined into a single sample. Rocks were removed, and algal material was collected using the pipe-scribe top rock scrape method described in Carpenter (2003). A round plastic scribe (short length of PVC pipe) with an outside diameter ranging between 4 and $10.4 \mathrm{~cm}$ was placed on each rock, and algal material outside the scribe was removed with a plastic-bristle brush or scraped off with a knife, and discarded. The circular patch of algae remaining on the rock was scraped into a small washbasin, and rinsed into a 1-L sample bottle using stream water. Samples were briefly homogenized with an electric blender, and subsamples were collected for chlorophyll- $a$, ash-free dry mass (AFDM), and species identification. Chlorophyll- $a$ and AFDM subsamples were collected on 45-micron glass-fiber filters, wrapped in foil, sealed, packed on dry ice, and shipped to the NWQL for fluorometric chlorophyll- $a$ (Arar and Collins, 1997) and gravimetric AFDM analyses (Britton and Greeson, 1987). All algae water samples were preserved in 5 percent buffered formalin solution and shipped to the Academy of Natural Sciences of Philadelphia for taxa identification and enumeration following protocols described by Charles and others (2002).

\section{Benthic Macroinvertebrate Assemblages}

One semiquantitative RTH sample for benthic macroinvertebrates was collected from five riffle areas in each stream. Each of the five subsamples were collected using a 500-micron mesh Slack sampling net (modified Surber design), which was placed in the stream, and rocks were cleaned of benthic organisms from a $0.25 \mathrm{~m}^{2}$ sampling area into the net. The five subsamples were combined in the field at each site. Additionally, one qualitative multihabitat (QMH) sample was collected using a 500-micron mesh dip net, which was used to collect and composite organisms from a diversity of microhabitats present at each site (for example, riffles, runs, pools, grasses, woody debris) into a 19-L bucket. Microhabitats were sampled equally for a maximum of 1 hour. Both individual sample types underwent a field elutriation process to clean and remove large organic debris, excess rocks, and sand. The composited macroinvertebrate sample was transferred into a 1-L plastic bottle, preserved with 10 percent buffered formalin, and shipped to the NWQL for taxa identification and enumeration (Moulton and others, 2002).

\section{Fish Assemblages}

Fish were collected using a Smith-Root Model BP2 backpack electro-shocker, with two separate upstream passes from the start to the end of the reach. Fish were caught using $6 \mathrm{~mm}$ mesh nets and stored in aerated live wells. All fish were identified and enumerated in the field after each sampling pass. The first 30 fish of each species were weighed to the nearest $0.1 \mathrm{~g}$, measured to the nearest millimeter, and checked for external anomalies (Moulton and others, 2002). The remaining individuals of each species were enumerated and checked for anomalies. Representative specimens of difficult to identify species were labeled and preserved in 10 percent buffered formalin solution and sent to the Department of Fish and Wildlife Ichthyology Museum at Oregon State University, Corvallis, Oregon, for identification verification. 


\section{Data Reduction and Analysis}

\section{Pesticide Toxicity Index Calculations}

To supplement the spatial comparison of individual pesticides among sites, a pesticide toxicity index (PTI) was calculated for each stream water sample (Munn and Gilliom, 2001). An additive model was used with the PTI to estimate potential toxicity of a water sample containing more than one pesticide. The toxicity was estimated by comparing stream concentrations to laboratory bioassay test endpoints such as the Lethal and Effect Concentrations for 50 percent of a test population $\left(\mathrm{LC}_{50}\right.$ and $\mathrm{EC}_{50}$, respectively) for three taxonomic groups of aquatic organisms (fish, benthic invertebrates, and cladocerans [water flea]) (Munn and others, 2006). Although the PTI does not determine the actual toxicity of a sample, it can be used to estimate and rank the relative toxicity of samples containing one or more pesticides. The PTI value was computed for each sample by summing the toxicity quotients (the measured concentration of a pesticide in a stream sample divided by its median toxicity concentration from bioassay tests) for all pesticides detected in a sample. Some pesticide compounds had no toxicological data for some or all of the three taxonomic groups. To maximize the number of pesticides included in the PTI, a single overall PTI was calculated using the most sensitive or lowest median toxicity concentrations for fish, benthic macroinvertebrates, and cladocerans. Limitations of the PTI include:

1. PTI was based on an additive model of pesticide toxicity (using combined toxicity-weighted concentrations of pesticides from multiple chemical classes without regard to mode of action), so the actual toxicity is not known because chemicals may act additively $(3+2+1=6)$, independently (not additively, $1+1+1+1=1$ ), or synergistically $(3+2+1=9)$;

2. PTI values were based on laboratory experiments (toxicity bioassays) of acute exposure that do not account for potential effects from repeated or chronic exposure. Environmental factors that may have affected bioavailability and toxicity, such as dissolved organic carbon (DOC) and temperature, were not incorporated into the PTI;

3. PTI was calculated for pesticides in samples taken from the water column, which may underestimate the toxicity from pesticides that accumulate in benthic sediments. This is especially true for hydrophobic compounds with moderate or high $\mathrm{K}_{\mathrm{oc}}$ values (for example, organophosphate insecticides or pyrethroid insecticides;

4. In some cases, the toxicity endpoint was based on a few, or in some cases just 1 laboratory test (the number of tests for an individual pesticide and taxonomic group ranged from 1 to 165); and
5. PTI values were calculated for just the three groups of aquatic organisms, not the full spectrum of aquatic life in these streams.

Despite its limitations, the PTI proved to be a useful measure for assessing the potential cumulative effects of pesticide on aquatic ecosystems, and for examining the relative toxicity of pesticides that do not currently have aquatic-life benchmarks.

\section{Explanatory Environmental Variables}

Five distinct environmental data sets were compiled, which included hydrology, water temperature, stream habitat, water chemistry, and watershed characteristics. These data sets were used to explain differences in algae, benthic macroinvertebrates, and fish at the 28 sites. Generally, the number of variables in each data set greatly exceeded the number of sampling sites $(\mathrm{n}=28)$; therefore, a large number of variables in each data set had to be eliminated with the remaining variables transformed and standardized to meet important statistical assumptions of normality and homogeneity of variance (Legendre and Legendre, 1998; Clarke and Gorley, 2006). The number of variables in each data set was reduced by analyzing the correlation matrix and scatter plots to eliminate strongly correlated, redundant variables. Appendixes in Sprague and others (2006) provide a complete list of all environmental variables sampled and used in our initial analyses.

After preliminary analysis with each environmental data set it became apparent that even with strong data transformations such as $\log (X+1)$, each data set still contained extreme values that dominated and skewed the distributions and results. Subsequently, all analyses used rank transformations to eliminate the influence of these extreme values. The multivariate BIO-ENV (biology-environment relationship using the BEST statistics routine in PRIMER) procedure in PRIMER, version 6 (Clarke and Ainsworth, 1993; Clarke and Gorley, 2006) was used to identify a subset of 5 to 10 variables in each data set that best explained the measured variation among the 28 sites from the initial larger number of variables in that data set. This procedure was completed separately for each data set, and then the final or "best of the explanatory environmental variables" were merged. The variables retained for each data set and detailed descriptions are listed in tables $\mathrm{A} 3$ to $\underline{\mathrm{A} 8}$.

In addition, a nutrient index was created by taking the first principle component (first axis) of a principle component analysis (PCA) on just the variables TN and TP, then converting the resulting axis scores to a scale from 0 to 100 . The first PCA axis of TN and TP explains the largest amount of variation across the 28 sites and therefore so does the nutrient index. 
The algal data was analyzed using multivariate statistics and algal water-chemistry metrics were calculated using Algal Data Analysis System (ADAS) software (Tom Cuffney, U.S. Geological Survey, written commun., 2007) that interfaced with an autecological compilation of water-quality indicator traits for more than 6,000 algal taxa (Porter, 2008). ADAS also created the diatom-only taxa-by-site data matrix used for the PRIMER analyses. Nearly all sites contained a high percentage of relatively small nondiatom taxa (mostly bluegreen and red algae) that overshadowed the signal from the diatoms. Much information is available on the tolerances and preferences of diatoms for several water chemistry parameters including nutrients, specific conductance, dissolved oxygen (DO), $\mathrm{pH}$, temperature, amount of organic matter, and current velocity. Therefore, multivariate and algal metric analyses were performed only on diatom data, and all-taxa datasets were characterized by relative density (number of cells $/ \mathrm{cm}^{2}$ ).

The Invertebrate Data Analysis System software (IDAS; Cuffney, 2003) was used to resolve taxa ambiguities for invertebrate data and to calculate about 140 benthic macroinvertebrate metrics commonly used in bioassessment (Davis and Simon, 1995; Barbour and others, 1999). Cuffney (2003) and Cuffney and others (2005) describe and discuss the issues of benthic macroinvertebrate taxa ambiguities that are beyond the scope of this report. The benthic macroinvertebrate metrics included measures of richness, percentage richness, density, percentage density, dominance, organism tolerance, and assemblage diversity. The tolerance metrics reported were based on the combination of regional tolerance values for the Pacific Northwest (B. Wisseman, Aquatic Biology Associates, Inc., written commun., 2003) or on professional judgment for taxa not covered in the Wisseman regional list. All tolerance values assigned to taxa followed the standard U.S. Environmental Protection Agency (USEPA) tolerance scoring of 0 to 10 from least to most tolerant (Barbour and others, 1999, Cuffney, 2003). Tolerance values then were compared to national and Pacific Northwest regional values reported by Cuffney (2003) to assure consistency and appropriateness. Tolerance metrics were calculated based on richness and abundance (Cuffney, 2003).

All invasive-fish counts were summed to create an aggregated nonnative "pseudospecies" to substitute for the individual nonnative counts (10) due to their limited individual occurrences among the sites. A fish index that summed the scores from four individual metrics also was computed: percentages of salmonids, reticulate sculpins, nonnative species and natives with reticulate and salmonids removed. Site values were given scores of $8,4,2$, or 1 if the value fell within different quartiles (less than 25 percent, 26 to 50 percent, 51 to 75 percent, or greater than 75 percent). Scores from the four metrics then were summed and converted to a 0 to 100 scale "fish index," with higher values indicating a more natural fish assemblage. The two native ammocoete lamprey (Lampetra) species were combined into the single category.
Biological data matrices commonly have numerous zero values and a few extreme values, resulting in a highly skewed distribution that requires some form of transformation to bring it closer to a normal distribution before statistical analyses can be completed (Legendre and Legendre, 1998; Clarke and Gorley, 2006). For all multivariate analyses, diatom density data was transformed using the square root function and benthic macroinvertebrate counts were converted to abundance values in number per square meter and log transformed (X + 1). The abundance data for fish species were log transformed $(X+1)$ to create the site-species matrix for multivariate analysis.

\section{Relating Biological Assemblages to Environmental Factors}

Associations between the environmental and biological data (algae, benthic macroinvertebrates, and fish assemblages) were examined using Spearman rank correlations (SAS version 8: Delwiche and Slaughter, 1998) and PRIMER multivariate statistical analyses (ordinations). Nonmetric dimensional scaling (nMDS) ordinations of the full assemblage data (for fish and benthic invertebrates) or the diatoms-only assemblage (for algae) were generated using Bray-Curtis similarity matrices for each biological assemblage (PRIMER, version 6: Clarke and Gorley, 2006). This method reduces the complex multidimensional nature of ecological data (for example, multiple species across many sites) to a reduced set of axes (1-4) that attempts to capture as much strength and explained variation among sites as the original multidimensional data matrix (for more detailed information on multivariate ordinations see Legendre and Legendre 1998). The result is a 2-axis plot where samples (sites) are positioned according to degree of similarity in taxonomic composition with each other. The goal is to reduce the complex multivariate species data to two ordination axes, which then may be correlated with environmental factors that may influence the species composition. In addition, the environmental matrix (Euclidian distance similarity) was related directly to the ecological matrices using the BEST procedure in PRIMER to determine the final subset of the environmental variables that best describe the variation in the ecological species matrix (nMDS ordination) among the 28 sites.

In this report, Spearman rank correlation coefficients (rho values) were considered strong when greater than or equal to 0.66 and moderate when between 0.66 and 0.50 . All rho values greater than 0.50 were statistically significant at $P$ less than 0.05 . The different analytical techniques used, such as scatter plots, summary graphs, correlations, and multivariate analyses, although common and robust, do not prove direct cause and effect. They are useful, however, for providing insights into ecological processes, for revealing potential environmental pathways, and for generating hypotheses. 


\section{Results}

\section{Physical Characteristics}

\section{Geographic Setting}

Urban and agricultural watershed development in the Willamette River basin and surrounding area followed the prevailing natural regional topography: most development was in the flat valley lowlands rather than in the higher elevation foothills and mountains. This was evident by the strong correlation between the natural environmental setting metrics (mean and minimum watershed elevation) and the urban indicator metrics (UII, percentage impervious surface, POPDEN00, percentage urban + agriculture, and ROADDEN (table 2). Environmental setting affected the natural characteristics of streams through variations in precipitation, erosion, and instream habitat as mediated by natural channel geomorphology and geology. Therefore, even without human influence, there were minor to moderate differences from the higher gradient foothill streams to the low-gradient valley streams. However, many of the environmental setting metrics overemphasized these differences because some variables were calculated for the whole watershed and not just the local area surrounding the sampling site. A good example was mean watershed slope and watershed elevation. Because many streams in the Willamette River basin and surrounding area originated in the foothills or mountains, calculated watershed metrics included parts of the higher elevation and higher gradient reaches even though the characteristics of the stream at the sampling site reflected the location of the stream with a low-gradient valley. The environmental setting metrics were calculated this way to provide measures of watershed characteristics that were consistent nationally and simple to calculate. There was an effort to minimize the natural differences among sites by selecting stream sampling reaches that were within the low-gradient valley, even though a large part of the upper watershed may be in a different ecoregion. For example, 75 percent of the sites were within $80 \mathrm{~m}$ of the overall mean elevation of $220 \mathrm{~m}$; sites ranged between $50 \mathrm{~m}$ and $620 \mathrm{~m}$ in elevation. Correlation of minimum watershed elevation to the urban indicator metrics, although still moderately statistically significant, was somewhat lower than the correlation of mean watershed elevation to the urban indicator metrics (table 2).

\section{Stream Hydrology}

Increased flow variability, or stream "flashiness" in the form of frequent high peaks and low troughs, is considered a key effect of urbanization on streams (Paul and Meyer, 2001; McMahon and others, 2003; Konrad and Booth, 2005; Roy and others, 2005). Konrad and Booth (2005), after reviewing the literature and analyzing a small number of sites with streamflow gaging stations from reference and urban dominated land use watersheds, determined that the frequency of "high-flow events as measured as the number of events three times above the median flow" and the "percent daily change" (flashiness) were the two most sensitive measures of changes in hydrographs due to urbanization. In their analysis, these two variables also were significantly correlated with algae, macroinvertebrates, and fish assemblage metrics. Data from this EUSE study corroborates these findings. For example, the four hydrologic variability metrics PeriodF5, PeriodF9, PeriodR5, and Richards-Baker Flashiness Index (Rb-flash), which related to rate in streamflow change, had

Table 2. Correlations of urban indicator metrics and environmental setting metrics, Willamette River basin and surrounding area, Oregon and Washington.

[See appendix A for variable definitions. Correlation coefficients were considered strong when $\geq 0.66$ (bolded and shaded) and moderate when $0.66>$ rho $\geq 0.5$ (bolded). Abbreviations: ROADDEN, road density; m, meter. Symbols: $\geq$, greater than or equal to; >, greater than; -, not applicable]

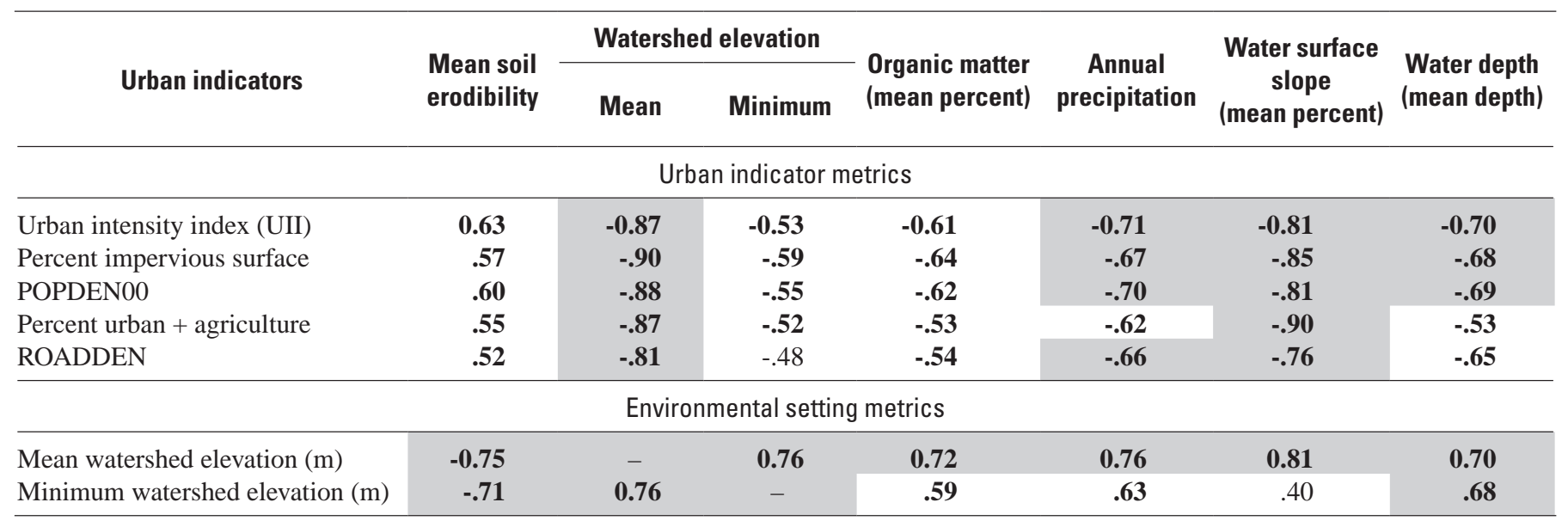


significant correlation with the urban indicator metrics (table 3). PeriodF5, PeriodF9 and PeriodR5 were metrics that summarized the frequency of periods of falling $(F)$ or rising (R) stream-discharge events, where hourly stream-discharge change was greater than or equal to 5 or greater than or equal to 9 multiplied by the median decrease or increase over the period of record (table A5). For example, PeriodF5 referred to the number of hours when streamflow fell over the period of record by at least five times the median flow for that site. The Rb-flash characterizes the degree that streamflow changed relative to the daily median. PeriodF9, the metric that documented the number of falling hydrologic events greater than nine times the site median, had the strongest correlation values - rho 0.69 with the UII (fig. 5) and 0.71 with road density (ROADDEN) (table 3). Associations among pairs of variables are shown as regression graphs (figs. 5 and 6) with simple linear or curvilinear trend lines added to aid interpretation.

Table 3. Spearman's rank correlations between urban indicator and water-chemistry metrics and select environmental variables, Willamette River basin and surrounding area, Oregon and Washington.

[See appendix A for variable definitions. Correlation coefficients were considered strong when absolute value $\geq$ (bolded and shaded) and moderate when $0.66>$ $r h o \geq 0.5$ (bolded). Abbreviations: ROADDEN, road density; TEQ, toxic equivalents; SPMD, semipermeable membrane device. Symbols: $\geq$, greater than or equal to; $>$, greater than]

\begin{tabular}{|c|c|c|c|c|c|c|c|c|}
\hline Stream and reach-scale variables & \multicolumn{6}{|c|}{ Urban indicators } & & \\
\hline \multicolumn{7}{|c|}{ Hydrologic variation metrics } & & \\
\hline Number of falling events $>5 \times$ median (PeriodF5) & 0.69 & \multicolumn{2}{|l|}{0.64} & 0.68 & 0.52 & 0.70 & & \\
\hline Richards-Baker Flashiness Index (Rb-flash) & .56 & \multicolumn{2}{|l|}{.49} & .55 & .41 & .53 & & \\
\hline \multicolumn{7}{|c|}{ Water temperature metrics } & & \\
\hline Minimum temperature (95th percentile) & 0.56 & 0.51 & \multicolumn{2}{|r|}{0.56} & 0.44 & $\mathbf{0 . 5 3}$ & & \\
\hline \multicolumn{9}{|c|}{ Habitat metrics } \\
\hline Percent large substrate & -.30 & -.23 & & -.30 & -.24 & -.27 & & \\
\hline Mean habitat heterogeneity & .30 & .21 & & .29 & .20 & .28 & & \\
\hline \multirow[b]{2}{*}{ Stream and reach-scale variables } & \multicolumn{8}{|c|}{ Water-chemistry variables } \\
\hline & $\begin{array}{l}\text { Summer- } \\
\text { time } \\
\text { dissolved } \\
\text { oxygen }\end{array}$ & $\begin{array}{c}\text { Dissolved } \\
\text { organic } \\
\text { carbon }\end{array}$ & $\begin{array}{c}\text { Total } \\
\text { insecti- } \\
\text { cides }\end{array}$ & $\begin{array}{c}\text { Total } \\
\text { pesticides }\end{array}$ & $\begin{array}{c}\text { TEQ } \\
\text { (SPMD) }\end{array}$ & $\begin{array}{l}\text { Average } \\
\text { specific } \\
\text { conduc- } \\
\text { tance }\end{array}$ & $\begin{array}{l}\text { Sulfate } \\
\text { concen- } \\
\text { tration }\end{array}$ & $\begin{array}{c}\text { Total } \\
\text { nitrogen } \\
\text { concen- } \\
\text { tration }\end{array}$ \\
\hline \multicolumn{9}{|c|}{ Hydrologic variation metrics } \\
\hline Number of falling events $>5 \times$ median (PeriodF5) & -0.45 & 0.71 & 0.71 & 0.50 & 0.70 & 0.42 & 0.56 & 0.40 \\
\hline Mean embeddedness (riffle and runs) & -0.66 & 0.46 & 0.36 & 0.39 & 0.41 & 0.69 & 0.55 & 0.52 \\
\hline Mean width/depth ration (riffle and runs) & .50 & -.34 & -.26 & -.10 & -.24 & -.59 & -.50 & -.35 \\
\hline Percent riffle habitat & .84 & -.60 & -.39 & -.33 & -.49 & -.61 & -.57 & -.46 \\
\hline Percent large substrate & .48 & -.21 & -.12 & -.06 & -.00 & -.36 & -.14 & -.05 \\
\hline Mean habitat heterogeneity & -.61 & .38 & .29 & .25 & .18 & .31 & .14 & -.05 \\
\hline
\end{tabular}




\section{Water Temperature}

Water temperature metrics generally did not correlate strongly with any urban indicator metrics; however, the minimum water temperature metric ( 95 th percentile) was positively correlated with the UII (0.56) (table 3) and negatively correlated with pollution sensitive diatoms (presented in the algae section, below). Because site selection was restricted to valley streams, the natural range in water temperature was narrow compared with the range in larger geographic areas or other ecosystems. Temperature data were lost during the hot summer months at three sites (Silk, Chehalem, and South Scappoose Creeks) due to transducer failure.

\section{Stream Habitat}

Stream habitat metrics did not have particularly strong correlation values with any urban indicator metrics; the strongest correlation was between percentage of riffle habitat and UII and POPDEN00, rho $=-0.63$ (table 3 ). The weak correlations among habitat metrics and urban indicator metrics likely were due to the study design; sites were selected to minimize natural differences to increase the chances of isolating the effects of urbanization (Short and others, 2005). Therefore, habitat measurements may have a better relation to changes in urbanization than was revealed in this study. Although not strongly correlated to urban indicators, certain habitat metrics did correspond well to water-chemistry metrics. For example, percentage of riffle habitat was strongly correlated with the summer DO concentrations (rho $=0.84$; fig. 6 ).

\section{Chemical Characteristics}

\section{Pesticide Occurrence}

Ninety-six stream samples were analyzed for 64 pesticides and degradation compounds. Among the samples, 28 pesticides or degradates were detected including 12 herbicides, 8 insecticides, 2 fungicides, and 6 degradates (fig. 7). At least one pesticide or degradation product was detected in 83 percent of the samples. Among all samples, the six most frequently detected pesticides were herbicides and herbicide degradates: atrazine, deethylatrazine (degradate of atrazine), simazine, hexazinone, prometon, and metolachlor.

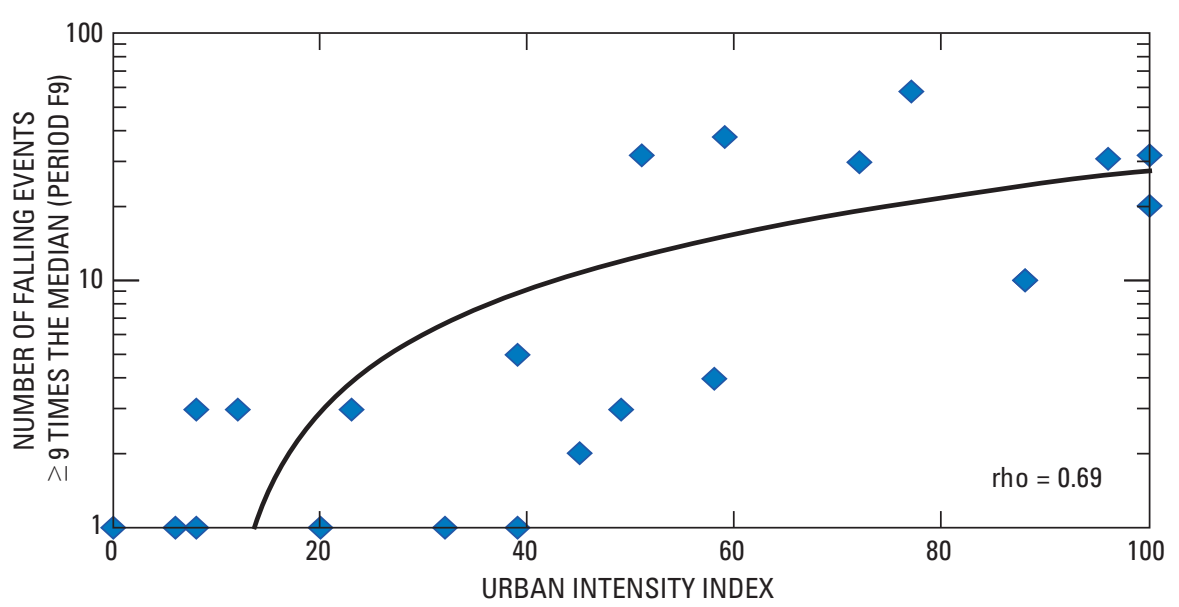

Figure 5. Relation between urban intensity index (UII) and number of falling hydrologic events greater than or equal to 9 times the median, Willamette River basin and surrounding area, Oregon and Washington.

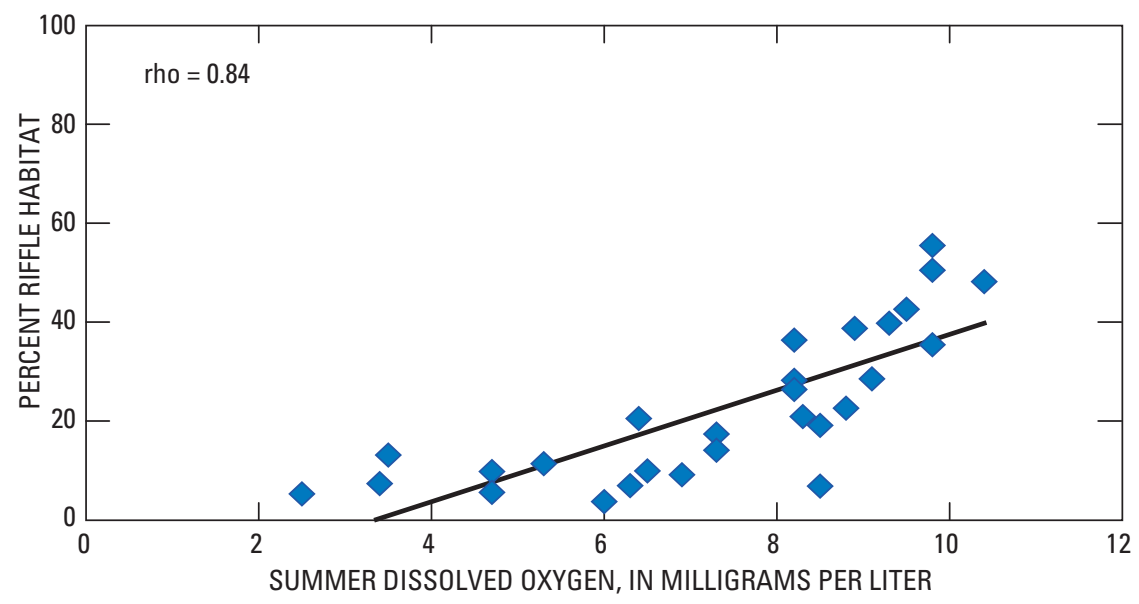

Figure 6. Percentage of riffle habitat in relation to summer dissolved oxygen concentrations, Willamette River basin and surrounding area, Oregon and Washington.
The highest frequency of occurrence was for atrazine, detected in 49 percent of all samples. Other pesticides with at least 10 detections include 3,4-dichloroaniline (degradate of diuron, and other phenylurea herbicides), tebuthiuron, trifluralin, carbaryl, diazinon, chlorpyrifos, metalaxyl, and myclobutanil. Ten or more pesticides were detected at 7 sites in either the spring or summer sampling; North Fork Deep Creek had 10 or more detections in both samplings (table 4).

Generally, individual pesticide concentrations were relatively low (fig. 7). The median concentration for any pesticide was $0.02 \mu \mathrm{g} / \mathrm{L}$ or less, and only seven pesticide concentrations exceeded $0.1 \mu \mathrm{g} / \mathrm{L}$. The highest concentration of any sample was $1.72 \mu \mathrm{g} / \mathrm{L}$ for atrazine, and the highest combined pesticide concentration for a sample was $2.08 \mu \mathrm{g} / \mathrm{L}$, occurring at Battle Creek during the spring 2004 sampling. 


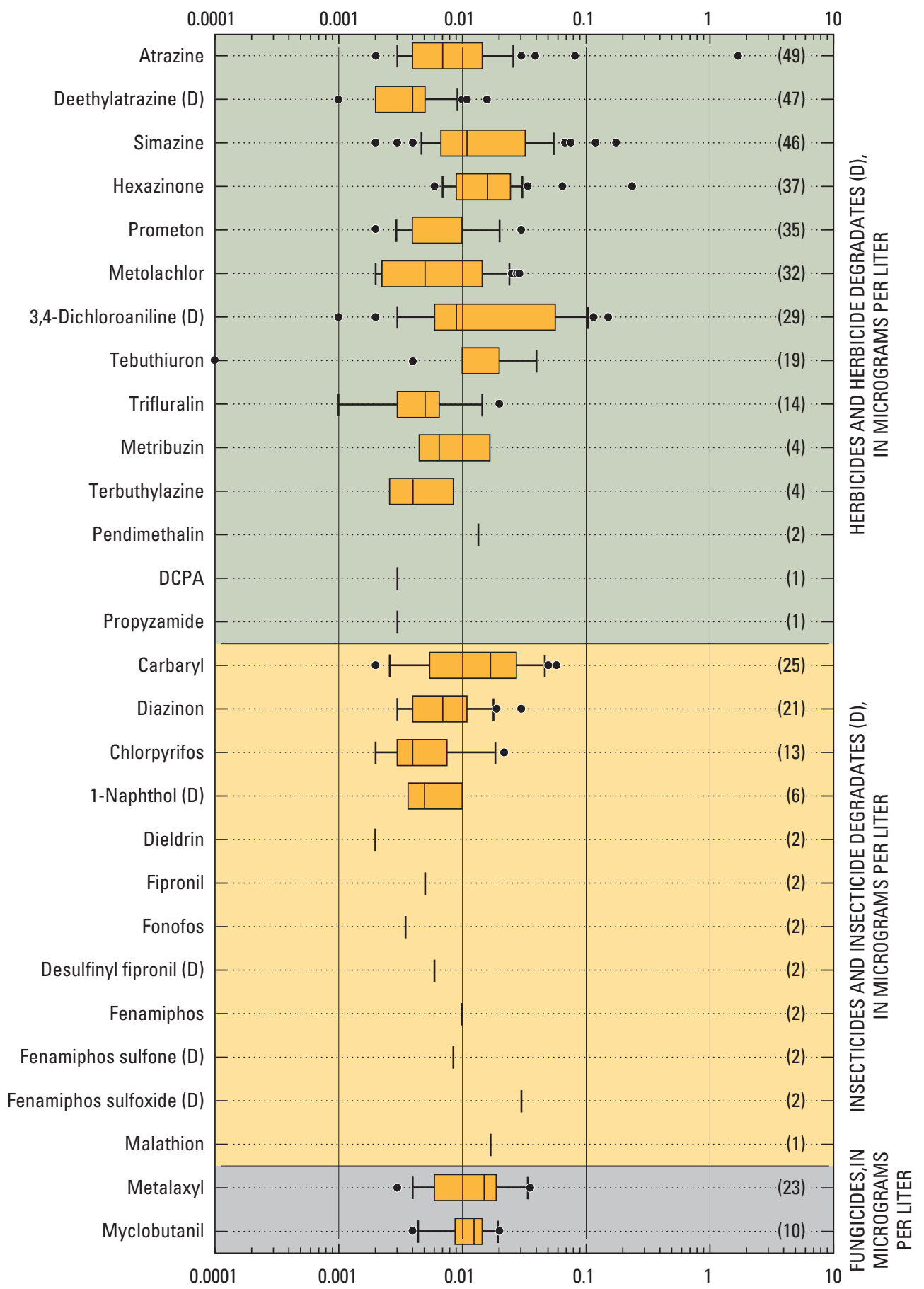

Figure 7. Pesticide concentrations and detection frequency for all stream samples, Willamette River basin and surrounding area, Oregon and Washington.Number in parentheses is equal to the total detections for that compound. 


\section{Seasonal Variability}

On average, there were more pesticide detections and higher pesticide concentrations during the spring sampling than during the summer (tables 4 and $\underline{5}$ ). For example, nearly twice as many pesticides were detected in spring, including 116 herbicides (including 24 degradates), 27 insecticides (including 4 degradates) and 8 fungicides, compared to summer when 61 herbicides (including 16 degradates), 16 insecticides (including 2 degradates) and 7 fungicides were detected (table 4). During spring sampling, 5 or more pesticides were detected at 16 sites, whereas during summer, at least 5 pesticides were detected at only 7 sites. Salmon Creek and Iler Creek, two minimally effected sites, were the only two streams with no pesticide detections in either spring or summer samplings. Most pesticide detections were in North Fork Deep Creek in both sampling periods likely because this area includes the highest amount of agricultural land use (48 percent) of any of the watersheds (U.S. Geological Survey, 2005). In addition to higher frequency of detections in the spring, total pesticide concentration for spring was more than 3 times greater than in summer, although a large part of this difference was due to one large concentration at Battle Creek, Oregon, during the spring sampling (table 5).

Herbicides were detected at 25 sites during the spring sampling and 19 sites in the summer (table 4). Atrazine, hexazinone, deethylatrazine, simazine, and prometon were the five most commonly detected herbicides in the spring, all with a detection frequency greater than 46 percent. During summer sampling the highest detection frequencies were for deethylatrazine, simazine, prometon, 3,4-dichloroaniline, and metolachlor, ranging between 25 and 43 percent, with prometon being the highest. Unlike atrazine, which primarily is used for agricultural purposes, and simazine, which is used in both urban and agricultural applications, prometon is used mostly for nonagricultural purposes, such as domestic and commercial applications to driveways, fence lines, lawns, and gardens. Prometon also can be used as an asphalt additive (Gilliom and others, 2006). Previous research documented a direct relation between urban land use and prometon detection frequency in surface water and ground water (Koplin and others, 1998), so it was not surprising to see such a high frequency of detection in our study. Where insecticides were detected, carbaryl and diazinon were predominant. Carbaryl, an agricultural and urban insecticide, was detected 39 percent of the time in spring and 18 percent in summer. Diazinon was detected slightly less than carbaryl in spring at 29 percent, yet slightly more in summer at 21 percent. Due to changes in pesticide regulations, residential uses of diazinon were cancelled in 2004, but use is still approved for agriculture.

\section{Temporal Variability}

During the 10 site "high frequency" sampling effort, pesticides were detected in all samples (6 sample times) for the 3 most highly-urbanized sites (Claggett, Pringle, and Kellogg Creeks) and in 2 mixed agricultural-urban sites (North Fork Deep and Tickle Creeks) (table 4). Pesticides were detected most frequently at North Fork Deep Creek, with at least eight pesticides detected in each sample. The fewest pesticides were detected in Salmon Creek, a predominantly forested watershed (UII $=20$ ), with only one detection in March 2004. This relatively low pesticide detection frequency in Salmon Creek likely was due to the low amount of agricultural land in this watershed ( 2 percent). Three pesticides were detected in three of the six samplings (50 percent) in the East Fork Dairy Creek watershed, even though it had only 1 percent combined urban plus agriculture land use (the site with the UII $=0$ ). This probably was due to the close upstream proximity to the sampling site of a variety of agricultural activities (for example, Christmas tree plantations and nursery operations) even though they were of small acreage and therefore did not add significantly to the total of agricultural land use summarized as a percentage of the total watershed area.

Overall, 44 of the 60 samples collected contained 2 or more pesticides and 11 of the 60 samples contained 10 or more pesticides. On average, between 5 and 11 pesticides were detected at the 3 most highly-urban sites during the 6 high frequency samplings, and between 1 to 3 pesticides were detected at the 3 lowest-urban sites. Streams draining predominantly urban watersheds have been shown to have higher detection frequencies and concentrations of some insecticides than other types of land uses (Anderson and others, 1997; Gilliom and others, 2006), and the results for this study followed this pattern. High frequency samples collected at the 3 most urban sites (UII $\geq 88$ ) (table 1) had a detection of at least one insecticide in 58 percent of samples; whereas high frequency samples collected at the 3 least urban sites (UII $\leq 20)$ had insecticide detections in only 8 percent of samples.

\section{Pesticide Metrics in Relation to Urban Intensity Index}

Relations between the UII and pesticide occurrence were strongest when considering the total number of pesticides and total concentration of all pesticides in a sample. For the spring and summer samplings a high UII was associated with a large number of pesticides detected in a sample. Comparison among groupings of sites based on the four levels of UII shaded in tables 4 and $\underline{5}$ (low: less than 10; medium: 10 to 25; high: 25 to 70 ; and very high: greater than 70 ) reveals some 
Table 4. Number of pesticide detections at each site by pesticide type for spring and summer 2004, Willamette River basin and surrounding area, Oregon and Washington.

[Sites are sorted by urban intensity index (UII). Shading from light to dark represents low, medium, high, and very high UII scores. Abbreviations: OR, Oregon; WA, Washington. Symbols: $\geq$, greater than or equal to; >, greater than; $<$, less than; $\leq$, less than or equal to]

\begin{tabular}{|c|c|c|c|c|c|c|c|c|c|c|}
\hline Site name & UII & \multicolumn{4}{|c|}{ Spring sampling } & \multicolumn{4}{|c|}{ Summer sampling } & $\begin{array}{c}\text { Total } \\
\text { detections }\end{array}$ \\
\hline $\begin{array}{l}\text { Beaverton Creek near SW 216th } \\
\text { Avenue, near Orenco, OR }\end{array}$ & 100 & 7 & 2 & 1 & 10 & 3 & 0 & 1 & 4 & 14 \\
\hline Claggett Creek at Keizer, OR & 100 & 7 & 1 & 0 & 8 & 4 & 2 & 0 & 6 & 14 \\
\hline Fanno Creek at Durham, OR & 96 & 8 & 2 & 0 & 10 & 1 & 2 & 1 & 4 & 14 \\
\hline $\begin{array}{l}\text { Amazon Creek near Danebo Road, at } \\
\text { Eugene, OR }\end{array}$ & 77 & 2 & 2 & 0 & 4 & 0 & 3 & 0 & 3 & 7 \\
\hline $\begin{array}{l}\text { Tryon Creek below Nettle Creek, near } \\
\text { Lake Oswego, OR }\end{array}$ & 72 & 2 & 3 & 0 & 5 & 5 & 3 & 0 & 8 & 13 \\
\hline Curtin Creek near Vancouver, WA & 69 & 5 & 0 & 1 & 6 & 2 & 0 & 0 & 2 & 8 \\
\hline Johnson Creek at Circle Avenue, OR & 59 & 8 & 1 & 1 & 10 & 4 & 1 & 1 & 6 & 16 \\
\hline Chicken Creek near Sherwood, OR & 45 & 6 & 2 & 0 & 8 & 1 & 0 & 0 & 1 & 9 \\
\hline North Fork Deep Creek at Barton, OR & 39 & 8 & 2 & 2 & 12 & 7 & 1 & 2 & 10 & 22 \\
\hline Oak Creek at Corvallis, OR & 39 & 1 & 0 & 0 & 1 & 0 & 0 & 0 & 0 & 1 \\
\hline Tickle Creek near Boring, OR & 32 & 6 & 1 & 1 & 8 & 7 & 2 & 1 & 10 & 18 \\
\hline Chehalem Creek at Newberg, OR & 29 & 7 & 2 & 0 & 9 & 2 & 1 & 0 & 3 & 12 \\
\hline Silk Creek near Cottage Grove, OR & 24 & 1 & 0 & 0 & 1 & 2 & 0 & 0 & 2 & 3 \\
\hline Rock Creek near Battleground, WA & 23 & 1 & 3 & 1 & 5 & 0 & 0 & 1 & 1 & 6 \\
\hline Salmon Creek near Battleground, WA & 20 & 0 & 0 & 0 & 0 & 0 & 0 & 0 & 0 & 0 \\
\hline Deep Creek near Sandy, OR & 17 & 4 & 0 & 1 & 5 & 2 & 0 & 0 & 2 & 7 \\
\hline Nate Creek near Colton, OR & 15 & 4 & 0 & 0 & 4 & 1 & 0 & 0 & 1 & 5 \\
\hline Milk Creek at Camp Adams, OR & 12 & 2 & 0 & 0 & 2 & 1 & 0 & 0 & 1 & 3 \\
\hline Urban intensity index & & & & & & erages & & & & \\
\hline $\mathrm{UII} \geq 70$ & 89 & 5.7 & 1.6 & 0.1 & 7.4 & 3.1 & 1.6 & 0.3 & 5.0 & 12 \\
\hline UII $>25-<70$ & 47 & 5.9 & 1.3 & .5 & 7.7 & 3.2 & .5 & .4 & 4.1 & 12 \\
\hline $\mathrm{UII}>10-\leq 25$ & 19 & 2.0 & .5 & .3 & 2.8 & 1.0 & 0 & .2 & 1.2 & 4 \\
\hline $\mathrm{UII} \leq 10$ & 5 & 1.0 & 0 & 0 & 1.0 & .2 & 0 & 0 & .2 & 1 \\
\hline
\end{tabular}


Table 5. Summary statistics of pesticide concentrations collected during spring and summer 2004, Willamette River basin and surrounding area, Oregon and Washington.

[Pesticide concentrations are in micrograms per liter. Sites are sorted by urban intensity index (UII). Shading from light to dark represents low, medium, high, and very high UII scores. Abbreviations: OR, Oregon; WA, Washington; SW, southwest. Symbols: $\geq$, greater than or equal to; >, greater than; <, less than; $\leq$, less than or equal to]

\begin{tabular}{|c|c|c|c|c|c|c|}
\hline Site name & UII & \multicolumn{2}{|c|}{ Sum pesticide } & \multicolumn{3}{|c|}{ Sum pesticides (spring and summer } \\
\hline Beaverton Creek near SW 216th Avenue near Orenco, OR & 100 & 0.077 & 0.053 & 0.012 & 0.090 & 0.028 \\
\hline Claggett Creek at Keizer, OR & 100 & .100 & .105 & .042 & .167 & 0 \\
\hline Fanno Creek at Durham, OR & 96 & .132 & .055 & .079 & .094 & .014 \\
\hline Pringle Creek at Salem, OR & 88 & .050 & .037 & .003 & .084 & 0 \\
\hline Tryon Creek below Nettle Creek, near Lake Oswego, OR & 72 & .025 & .066 & .037 & .054 & 0 \\
\hline Curtin Creek near Vancouver, WA & 69 & .026 & .007 & 0 & .029 & .004 \\
\hline Johnson Creek at Circle Avenue, OR & 59 & .361 & .225 & .022 & .498 & .066 \\
\hline Battle Creek near Turner, OR & 58 & 2.08 & .158 & .026 & 2.21 & 0 \\
\hline Rock Creek at Quatama Road near Hillsboro, OR & 51 & .214 & .055 & .054 & .220 & 0 \\
\hline Whipple Creek near Salmon Creek, WA & 49 & .014 & 0 & .002 & .012 & 0 \\
\hline Tickle Creek near Boring, OR & 32 & .049 & .058 & .011 & .071 & .025 \\
\hline Chehalem Creek at Newberg, OR & 29 & .190 & .057 & .019 & .232 & 0 \\
\hline Silk Creek near Cottage Grove, OR & 24 & .018 & .038 & 0 & .056 & 0 \\
\hline Rock Creek near Battleground, WA & 23 & .060 & .015 & .038 & .002 & .035 \\
\hline Salmon Creek near Battleground, WA & 20 & 0 & 0 & 0 & 0 & 0 \\
\hline Deep Creek near Sandy, OR & 17 & .039 & .018 & 0 & .054 & .003 \\
\hline Nate Creek near Colton, OR & 15 & .023 & .002 & 0 & .025 & 0 \\
\hline Milk Creek at Camp Adams, OR & 12 & .018 & .005 & 0 & .023 & 0 \\
\hline South Scappose Creek at Scappose, OR & 8 & .004 & 0 & 0 & .004 & 0 \\
\hline North Yamhill Creek near Yamhill, OR & 8 & 0 & .010 & 0 & .010 & 0 \\
\hline Lost Creek near Dexter, OR & 6 & .007 & 0 & 0 & .007 & 0 \\
\hline Iler Creek near Forest Grove, OR & 4 & 0 & 0 & 0 & 0 & 0 \\
\hline $\mathrm{UII} \leq 10$ & 5 & .005 & .002 & 0 & .007 & 0 \\
\hline
\end{tabular}

interesting patterns. For example, when summed across the spring and summer samplings, an average of 12 pesticides were detected in both the high and very high UII groups (table 4). The number of detections dropped substantially, four pesticides detected on average, when only looking at medium UII sites and only one pesticide was detected on average in low UII sites (UII less than 10) (table 4). The pattern of herbicide concentrations varied from this, as average total herbicide concentrations were higher for high UII sites than when compared to very high UII sites (UII greater than 70 ), even though the number of herbicide detections were the same between these two groups of sites. The higher herbicide concentrations of the high UII group compared to the very high UII group remained even after the extreme herbicide value from Battle Creek was removed. However, for insecticides, the average concentration was more than 2.5 times greater in the very high UII group of sites than the high UII group. 
The fact that the high UII group averaged as many pesticide detections as the very high group, likely was due to the influence of agricultural land use in the watersheds. The amount of agricultural land in the watersheds in the high UII group ranged from 16 to 48 percent (an average of 31 percent), and the amount of urban ranged 7 to 72 percent (an average of 30 percent) (table 1 ; fig. 8). Therefore, many high category UII watersheds had about the same amount of influence from agricultural land use as urban land use. On the other hand, the very high UII category, which was dominated by urban land use (60-98 percent urban), had a relatively minor influence from agricultural land use ( $0-8$ percent agriculture). In terms of the number of pesticides detected in streams, little difference was observed between agricultural and urban land; however, the composition of the pesticide mixture and the timing of delivery to the stream varied considerably between agricultural and urban sites in the study. These differences in pesticide detection frequency and types of pesticides between agriculture and urban land use are similar to those reported in the Willamette Valley by Anderson and others (1997) and in streams across the country by Gilliom and others (2006).

Among individual pesticides detected during this study, only prometon showed a significant correlation with UII (rho $=0.70)$, and then only during the spring sampling. Total pesticide and insecticide concentrations (log transformed due to extreme values that skew the distribution; $\log [\mathrm{X}+$ $0.0001]$ summed across spring and summer) were strongly correlated with the UII (rho $=0.68$ and 0.69 , respectively) (figs. 9, 10, and table 6). The correlation of log total pesticide concentration increased slightly when correlated to percentage urban plus agricultural land (rho $=0.72$ ), yet the correlation decreased dramatically when related to only percent agricultural land (rho $=0.41$ ). Conversely, the correlation of log total insecticide concentration decreased when related to urban plus agricultural land compared to its correlation to UII (rho $=0.63$ and 0.69 , respectively) (table 6). This suggests that many insecticide detections originated from applications in urban areas, not from the agricultural uses.

\section{Pesticide Toxicity Index in Relation to Urban Intensity Index}

PTI scores at the 28 sites typically were greater in spring than summer (18 greater, 8 less, 2 the same). The difference between most pairs of PTI scores was small, as 20 of the 28 scores changed by one order of magnitude or less between the two samplings. The sum of the spring and summer PTI values was used to estimate the potential pesticide toxicity among sites and to follow our summary of actual pesticide detections and concentrations presented previously in this report. The sum of the PTI was significantly correlated with the UII (rho $=0.63$, fig. $11 \mathrm{~A}$ ), yet had a stronger correlation to ROADDEN at rho $=0.69$ (fig. $11 B$ ). The relation of PTI to ROADDEN was curvilinear and revealed two basic groups of sites with relatively high PTI values. One group of sites with the highest road density (ROADDEN greater than 10) also had the highest percentage of urban land use or highest UII values. Another group of sites with moderate road density had a combination of moderate percentage of urban land and substantial amounts of agricultural land (ROADDEN of 3.5 to 8.5 and PTI values greater than 4). This pattern followed the results of a number of pesticide detections stated above, such that high detection frequencies occurred at sites with high urban land use and at sites with lower amounts of urban land use but with moderate amounts of agricultural land.

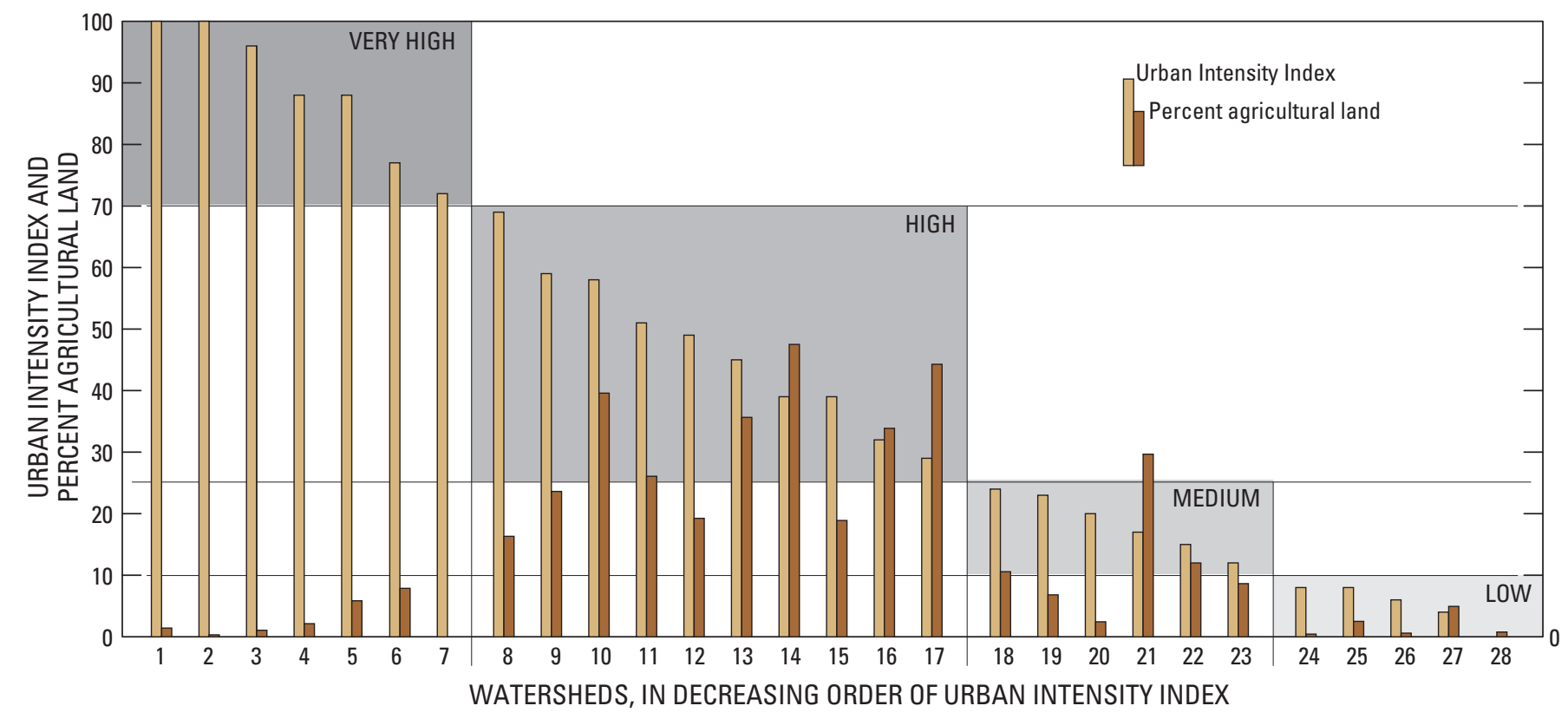

Figure 8. Urban intensity index (UII) and percentage of agricultural land for all 28 sites, Willamette River basin and surrounding area, Oregon and Washington. 


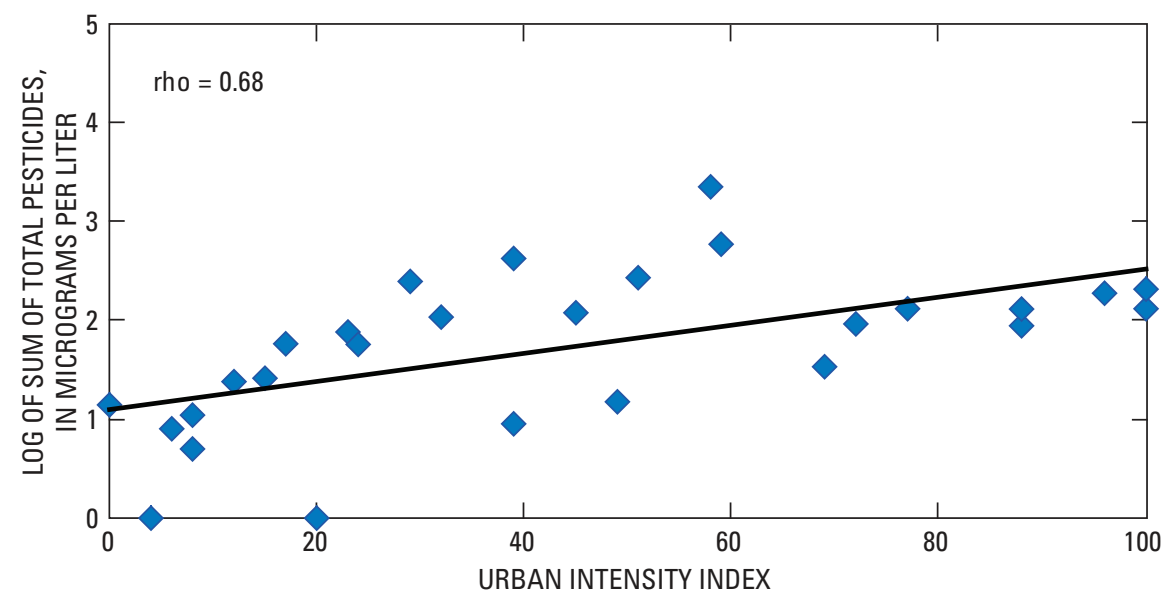

Figure 9. Total pesticide concentration in relation to urban intensity index (UII) for all 28 sites, Willamette River basin and surrounding area, Oregon and Washington.

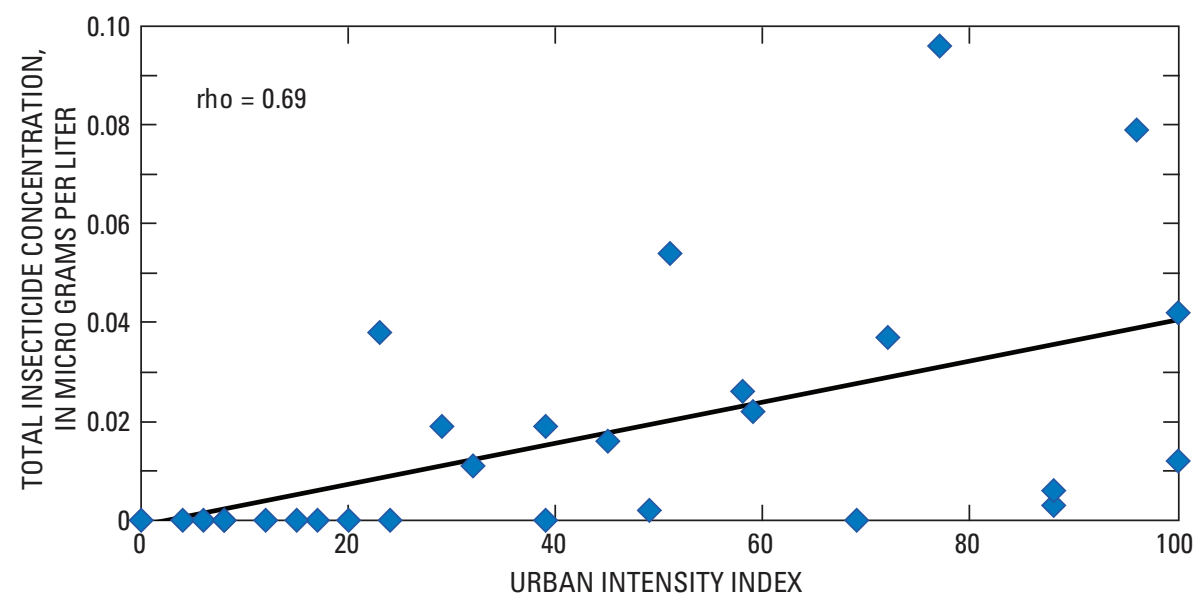

Figure 10. Total insecticide concentration in relation to urban intensity index (UII) for all 28 sites, Willamette River basin and surrounding area, Oregon and Washington.

Table 6. Spearman's rank correlation coefficients (rho values) between urban indicator and water-chemistry variables, Willamette River basin and surrounding area, Oregon and Washington.

[Average dissolved organic carbon (DOC), sulfate $\left(\mathrm{SO}_{4}\right)$, total nitrogen (TN), total phosphorus (TP) concentration values were used for the correlations. Correlation coefficients were considered strong when absolute value $\geq 0.66$ (bolded and shaded) and moderate when $0.66>$ rho $\geq 0.50$ (bolded). Abbreviations: PTI, Pesticide Toxicity Index; TEQ, toxic equivalents index; DO, dissolved oxygen; ROADDEN, road density. Symbol: $\geq$, greater than or equal to]

\begin{tabular}{|c|c|c|c|c|c|c|c|c|c|c|c|}
\hline Urban indicators & \multicolumn{2}{|c|}{ Sum of spring + summer } & \multicolumn{9}{|c|}{ Water-chemistry variables } \\
\hline Percent impervious surface & .65 & .65 & .61 & .80 & .64 & -.56 & .65 & .72 & .83 & .71 & .86 \\
\hline POPDENOO & .70 & .68 & .62 & .81 & .66 & -.61 & .70 & .71 & .81 & .73 & .85 \\
\hline Percent urban + agriculture & .63 & .72 & .60 & .73 & .58 & -.53 & .60 & .62 & .86 & .65 & .84 \\
\hline
\end{tabular}




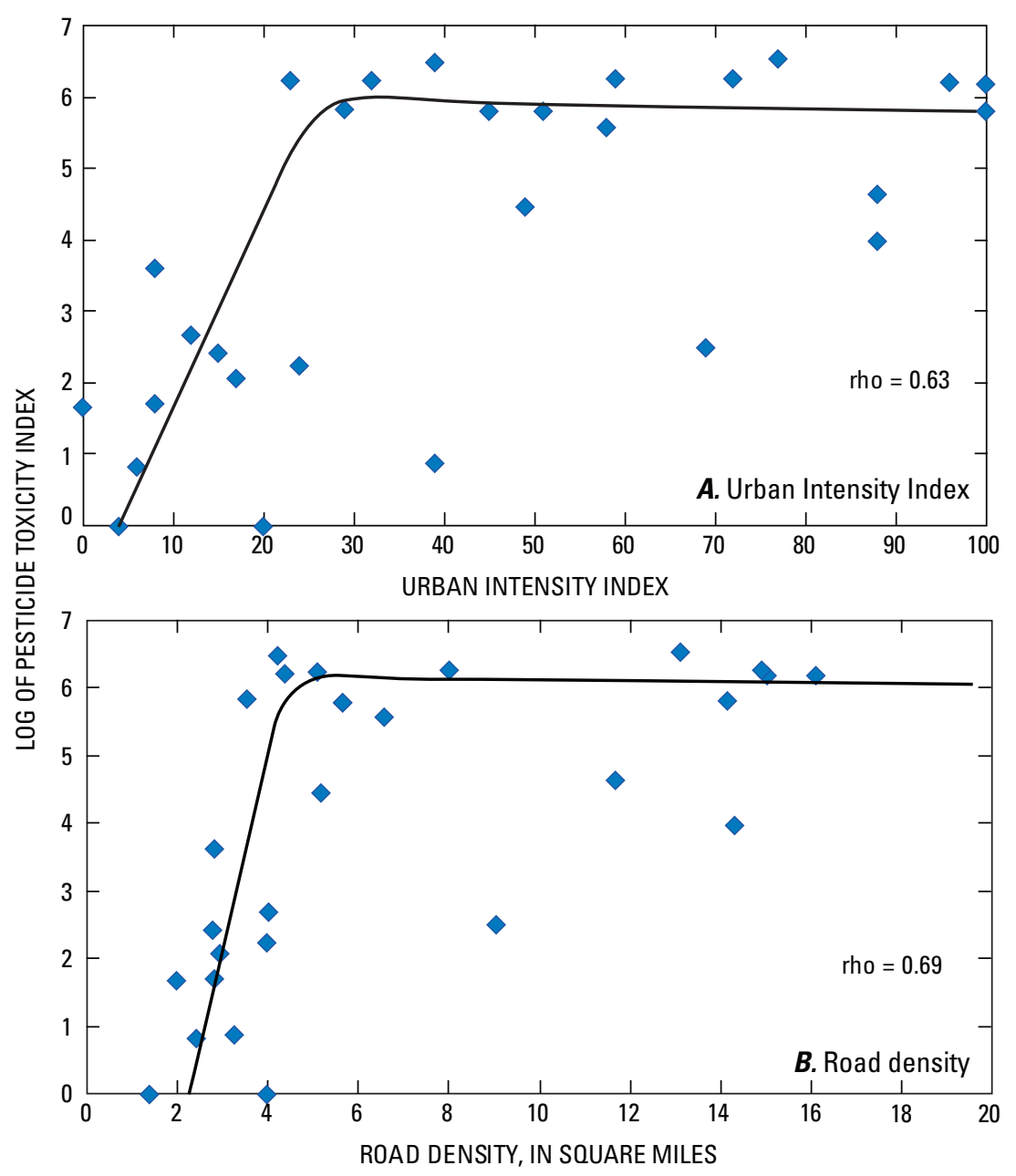

Figure 11. Relations between Pesticide Toxicity Index (PTI) and ( $A$ ) urban intensity index (UII) and (B) road density (ROADDEN), Willamette River basin and surrounding area, Oregon and Washington.

\section{Semipermeable Membrane Device Assays in Relation to} Urban Intensity Index

Of the three assays run on the SPMDs, the toxic equivalents (TEQ) index (P450 RGS assay for aryl hydrocarbon receptor agonists) and Pyrene Index (fluoroscan for total PAHs) provided consistent and reliable results. No interpretable results were achieved from the Microtox $®$ assay and are not discussed (Bryant and others, 2007). The TEQ and Pyrene Index assays were correlated to the five urban indicator metrics, with TEQ having the strongest correlation to both UII and POPDENO0 at rho $=0.81$ (table 6; fig. 12). Bryant and others (2007) determined similar strong correlations of the TEQ and Pyrene indices compared to the individual UIIs of other USGS EUSE studies in Atlanta, Georgia; Raleigh-Durham, North Carolina; Denver, Colorado; DallasFort Worth, Texas; and Milwaukee-Green Bay, Wisconsin.
They also concluded that the strong correlation of UII with pentachloroanisole and pyrogenic PAHs in the other study areas was evidence that these compounds were an important part of urbanization regardless of geographic location.

Along with the three assays, part of each SPMD dialysate was analyzed for hydrophobic chemical compounds. Of the 141 compounds targeted for identification by gas chromatography and mass spectrometry analysis, 39 were detected in the Willamette River basin and surrounding area. In comparison, detection in the other 5 EUSE studies ranged from 49 compounds detected in Raleigh-Durham to 36 in Dallas-Fort Worth (Bryant and others, 2007). Only three PAH compounds detected in the Willamette River basin and surrounding area were significantly correlated to the UII, and this was the lowest number of significant correlations among the six EUSE studies (high of 21, Raleigh-Durham). 

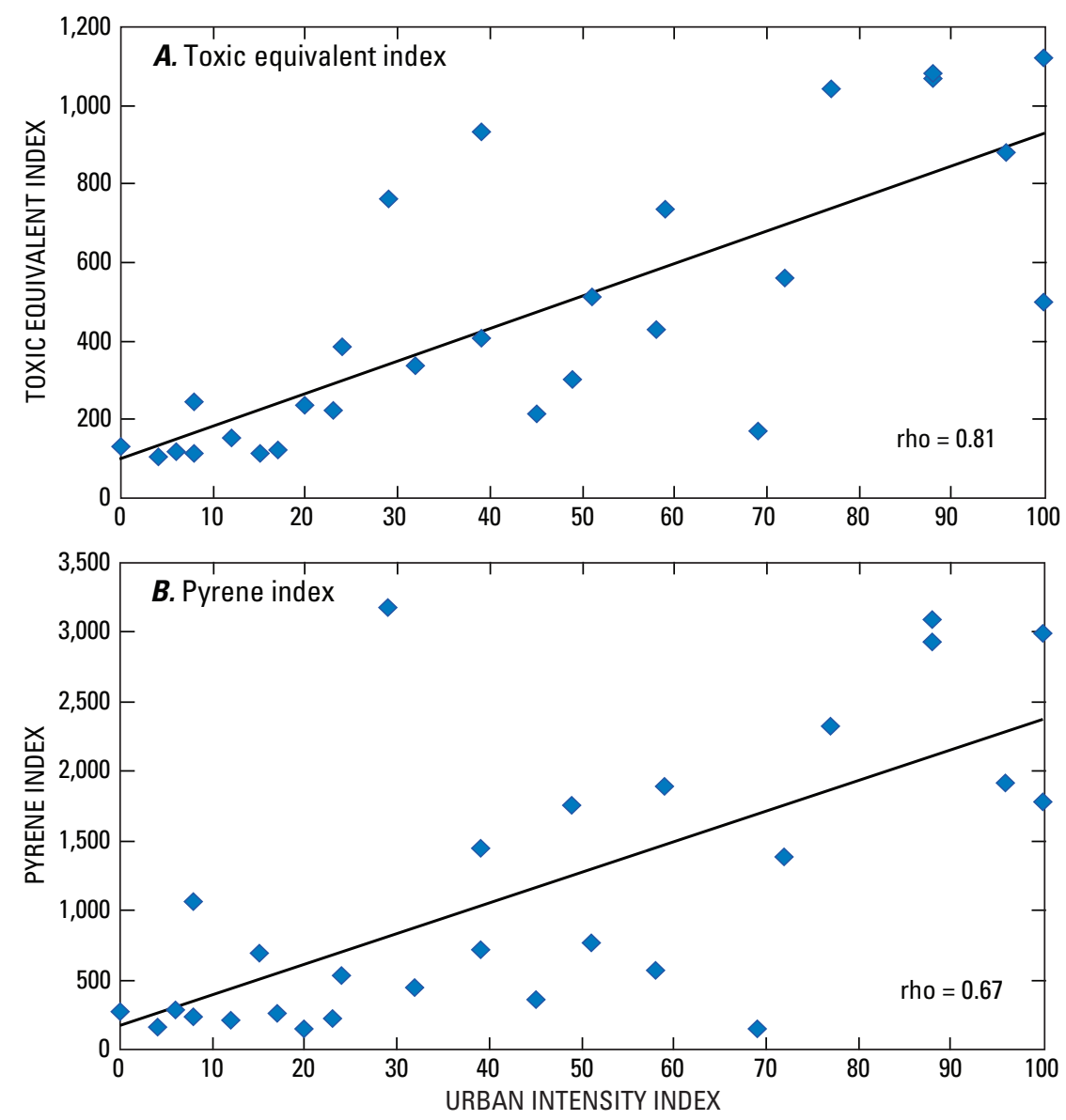

Figure 12. Relation between the urban intensity index (UII) and semipermeable membrane device results for the $(A)$ toxic equivalent index (TEO) and (B) pyrene index.

\section{Nutrients and Field Parameters}

For spring and summer samplings, total nitrogen (TN), total phosphorus (TP), and orthophosphorus (soluble reactive phosphorus; SRP) had positive correlations with the UII (table 6). The highest two TN concentrations of all sampling sites were in Curtin Creek during spring and summer (4.8 and $3.9 \mathrm{mg} / \mathrm{L}$, respectively). Curtin Creek was considered an outlier due to the relatively high TN values measured, which were probably caused by the large amount of groundwater inflow (ground-water that is high in DO and TN due to the natural coarse grain geology, which likely minimizes the amount of denitrification) just upstream of the sampling site. TN concentrations averaged for the spring and summer samplings and nutrient index were positively correlated to the UII (TN: rho $=0.79$; fig. $13 A$ ) (nutrient index: rho $=0.85$; table 6). The highest TP concentration $(0.18 \mathrm{mg} / \mathrm{L})$ was in Beaverton Creek in spring, and in Claggett Creek in summer $(\mathrm{TP}=0.28 \mathrm{mg} / \mathrm{L})$.
Some of the highest $\mathrm{TN}$ values were in the medium to high UII groups of sites (UII 25 to 70), likely due to the increased amount of agricultural land at these moderately urban sites (fig. 8). As a result, the correlation of TN increased further when percentage of agricultural land was included with percentage of urban land as the correlative variable $($ rho $=0.86$; fig. $13 B)$. Nevertheless, lower TN concentrations (generally less than $0.5 \mathrm{mg} / \mathrm{L}$ ) were detected in sites with relatively low urban development (UII less than 25), whereas relatively higher $\mathrm{TN}$ concentrations ranging from 0.7 to $2.3 \mathrm{mg} / \mathrm{L}$ were commonly detected in higher UII sites (greater than 25), (not including the outlier value for Curtin Creek). The pattern for TP was not as consistent as shown for TN and its correlation decreased when the amount of agriculture was included (table 6), nevertheless, high UII sites generally had the highest TP concentrations ranging from 0.08 to $0.28 \mathrm{mg} / \mathrm{L}$.

Phosphorus concentrations (TP and SRP) in many stream sites increased from spring to summer as streamflow decreased towards base-flow. This likely was due to inputs 


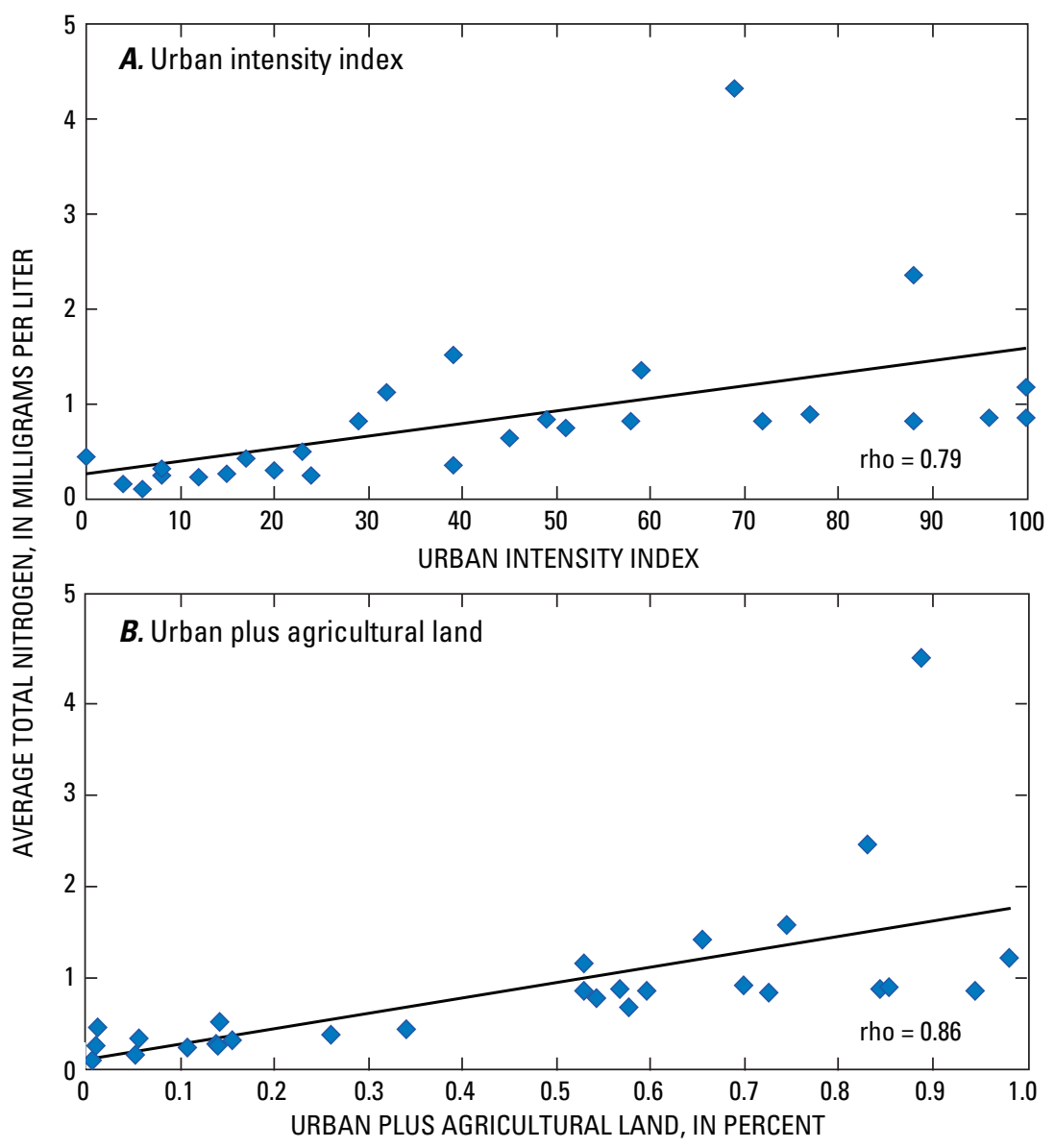

Figure 13. Relations between average total nitrogen concentrations and $(A)$ urban intensity index (UII) and (B) percentage of urban plus agricultural land, Willamette River basin and surrounding area, Oregon and Washington.

of phosphorus in ground water to streams, though other possible explanations include increased water use and increased influences of wastewater inputs from septic systems or treatment plants. Twenty-two of the 28 sites showed this pattern of increased SRP from summer to spring. Nitrogen concentrations, however, decreased from spring to summer and were more variable than phosphorus concentrations, possibly reflecting inputs from runoff of spring fertilizer applications in urban and agricultural land that may have subsided during the dry summer months. Most streams showed decreased concentrations of dissolved inorganic nitrogen (DIN) through the growing season, which may reflect the tendency for nitrogen to be in relatively short supply compared with phosphorus in some Northwest streams, particularly during summer (Carpenter, 2003). About one-third of the streams had DIN concentrations that were 0.5 to $1.7 \mathrm{mg} / \mathrm{L}$ lower during summer compared with spring. The greatest change in the DIN concentration from spring to summer was in North
Fork Deep Creek, where nuisance levels of filamentous green algae (Cladophoraglomerata) contributed to relatively high chlorophyll- $a$ levels $\left(157 \mathrm{mg} / \mathrm{m}^{2}\right)$.

Among the water chemistry variables, strongest correlations to the UII (rho greater than 0.70) was for DOC and dissolved sulfate $\left(\mathrm{SO}_{4}\right.$; table 6) whereas, specific conductance, bicarbonate alkalinity, chloride, and summer dissolved oxygen (DO) (negative) also were correlated, but slightly less significantly (rho greater than 0.50). Sulfate sources include fertilizers, road pavement amendments, and certain algicides (copper sulfate, for example), and is often produced during combustion. Sulfate also is produced when bacteria in organic soils oxidize hydrogen sulfide $\left(\mathrm{H}_{2} \mathrm{~S}\right)$. Potential sources of bicarbonate in urban areas include the slow erosion of concrete structures, sidewalks, and roadways, and calcium carbonate based lime products applied to lawns for $\mathrm{pH}$ control. 
DO is a critical parameter for aquatic life in streams, and is affected by a number of processes, including water temperature, atmospheric pressure, and the activity of bacteria, algae, and other aerobic organisms that consume DO, and processes that produce it (aeration in riffles, for example, and photosynthesis by algae). All DO data used in this report were instantaneous measurements collected during midday, and do not reflect the daily cycle of DO that often occurs in nutrientenriched streams with high algal production. It is likely that in many of these urban nutrient-enriched streams the DO may show large diurnal swings; very low DO in early morning after nighttime anerobic activity and super-saturated DO in late afternoon after photosynthesis by abundant algae.

\section{Biological Characteristics}

\section{Algae Assemblages}

Algal assemblages were dominated by pennate diatoms (Pennales Order), which comprised 214 of the 254 algal taxa identified in RTH (richest target habitat) riffle samples from the 28 sites (table 7; table A9). Based on biomass, however, Chlorphytes (green algae) were dominant, contributing on average about 70 percent of the total algal biovolume, whereas diatoms comprised 17 percent of the total algal biovolume. The most common diatoms in RTH samples were Achnanthidium minutissimum, Rhoicosphenia

Table 7. Most common algal taxa from the five major Divisions identified in Richest Targeted Habitat samples, Willamette River basin and surrounding area, Oregon and Washington.

[Number of streams: One Richest Targeted Habitat (RTH) algal sample was collected from each of 28 streams. Abbreviation: $\mathrm{cm}^{2}$, square centimeter]

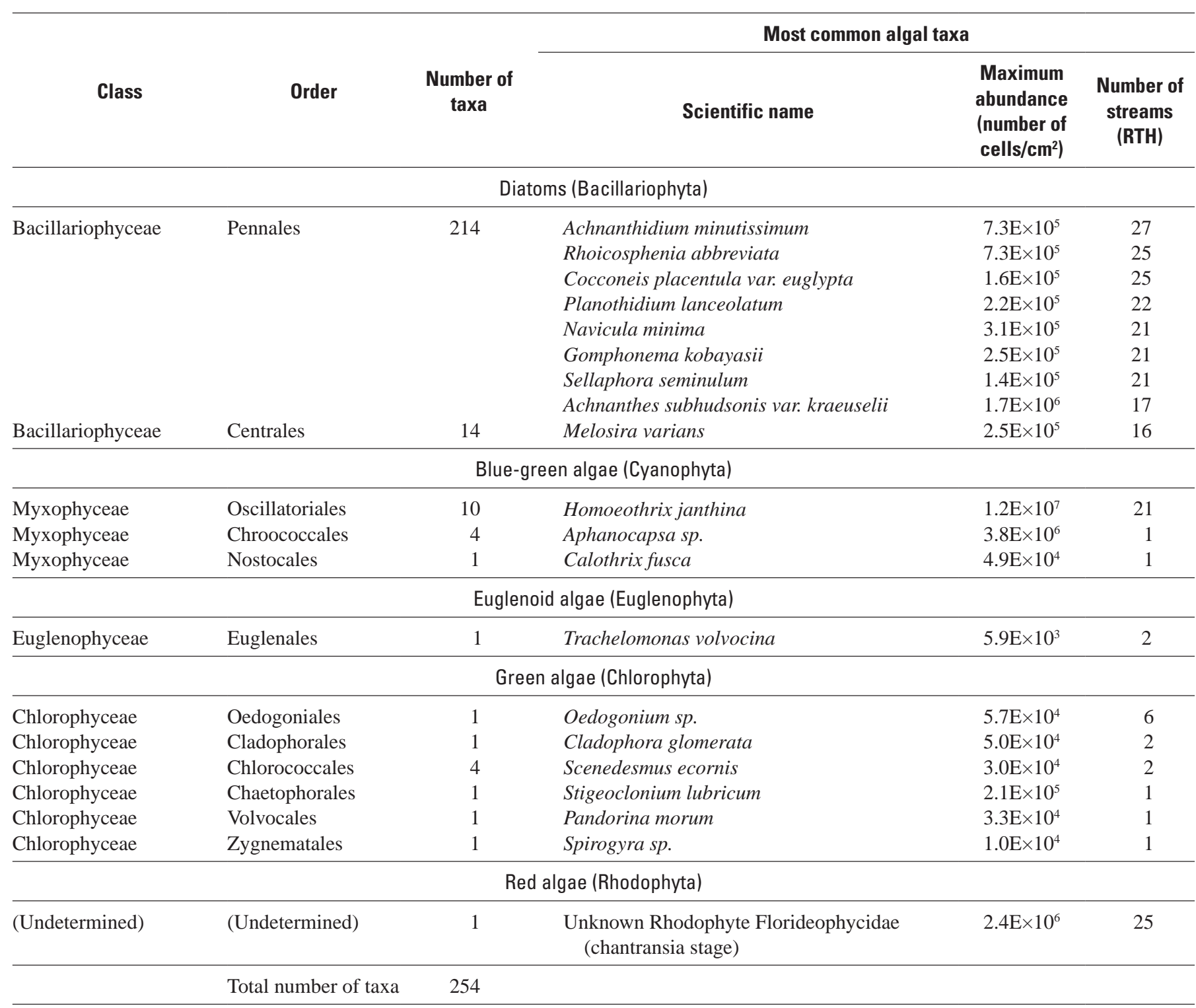


abbreviata, Cocconeis placentula var. euglypta, Planothidium lanceolatum, Navicula minima, Gomphonema kobayasii, Sellaphora seminulum and Achnanthes subhudsonis var. kraeuselii (table 7).

Based on cell density (number of cells $/ \mathrm{cm}^{2}$ ) blue-green and red algae were the dominant taxa at all but one site (Deep Creek), with the blue-green Homeothrix janthina dominating 11 sites and unidentified red algae (vegetative "chantransia" stage) six sites (table 8). The red and blue-green algae have relatively small cells, and, therefore, tended to dominate cell densities. Many dominant diatoms, particularly at sites high on the UII, were high-nutrient (eutrophic) taxa, or preferred high TN concentrations, and were tolerant of moderate levels of DO (greater than 75 percent saturation) (table 8). Although many sites lower on the UII also were dominated by eutrophic diatom taxa, several were dominated by Achnanthes and Achnanthidium species whose water-quality preferences have not yet been established.

Sixty-seven percent of the total algal biovolume (for all RTH samples combined) was comprised of filamentous green algae, including Cladophora glomerata, Stigeoclonium, Odeogonium, and Spirogyra (table 7). The occurrence of these high-biomass forming filamentous green algae was sporadic along the UII, as they were detected at few sites despite relatively high nutrient levels. In addition to requiring high nutrients, these taxa also prefer relatively high light levels, which was limited in some streams where riparian vegetation or topographic relief provided shading. High sediment concentrations in some streams also may have limited light availability. Potapova and others (2005) determined that light conditions affected algal assemblages in streams around Salt Lake City, Utah, due to riparian vegetation, stream size, and suspended sediment. Carpenter and Waite (2000) determined filamentous blue-green algae, such as Oscillatoria, to be common in silt-laden agricultural streams in the Willamette Valley, possibly due to their ability to move and unbury themselves after siltation events, or from an inherent ability to grow under low light conditions.

\section{Response in Algal Biomass to Urban Intensity Index}

Benthic algal biomass was highly variable along the urban gradient, with chlorophyll- $a$ values ranging from 5 to $212 \mathrm{mg} / \mathrm{m}^{2}$, and showed no obvious response to urbanization (fig. 14A). AFDM, a measure of the organic matter present, ranged from 2.4 to $70 \mathrm{~g} / \mathrm{m}^{2}$, and was positively correlated with the UII (rho $=0.56$; fig. $14 B$ ) and the nutrient index (rho $=0.72$; fig. $15 A$ ). All but one site less than 25 on the UII had an AFDM value that indicated at least a moderate degree of organic enrichment, and many sites higher on the UII (greater than 25) exceeded the criterion to be considered organically enriched (fig. 15A; Biggs, 1996). Twelve of 28 streams had chlorophyll- $a$ concentrations exceeding $50 \mathrm{mg} / \mathrm{m}^{2}$, a low-end threshold suggested to protect recreational and aesthetic qualities of streams (Biggs, 1996). The highest chlorophyll- $a$ concentrations occurred in North Fork Deep and Amazon Creeks (157 and $212 \mathrm{mg} / \mathrm{m}^{2}$, respectively) due to high abundances of Cladophora glomerata, Oscillatoria princes, and Sellaphora seminulum (fig. 14A). The chlorophyll- $a$ concentrations in these streams also exceeded common nuisance indicator levels for benthic algae $100-150 \mathrm{mg} / \mathrm{m}^{2}$ (Horner and others, 1983; Welch and others, 1988, 1989; Biggs, 1996; Dodds and others, 1997, 1998). Proliferations of algae may develop quickly during periods of stable streamflow, especially in streams receiving nutrients. Newall and Walsh (2005) found that repeated rainfall events can stimulate algal growth in streams by providing pulses of nutrients, an effect that was enhanced by the amount of impervious surface and the degree of drainage connection within the storm-water network.

Although there was considerable variation between AFDM and DOC (fig. 15B), the highest AFDM values occurred when the DOC exceeded about $4 \mathrm{mg} / \mathrm{L}$, and DOC was negatively correlated with DO concentrations (fig. 15C). Taken together, the relations among algal biomass, DOC, and DO indicate that algal biomass may be affecting DO levels through bacterial decomposition processes involving the production of DOC. DO also is affected, however, by water temperature and the amount of riffle habitat that aerates the water (fig. 6). Because diurnal fluctuations in $\mathrm{DO}$ and $\mathrm{pH}$ can occur from algal photosynthesis, however, the one-time instantaneous midday measurements collected for this study likely do not fully reflect the processes of photosynthesis and respiration that may occur in these streams.

Elevated levels of dissolved nutrients can stimulate the growth of benthic and planktonic algae in streams. In some cases, high-biomass forming benthic algae such as filamentous Chlorophytes (green algae) may cover streams and foul substrates when high amounts of light are available for photosynthesis (Carpenter and Waite, 2000). In addition to the prolific growths of green algae described above, another high-nutrient indicator alga-Melosira varians-was detected at more than 50 percent of the sites (16 sites; table 7), making up about 10 percent of the total biovolume for all RTH samples. This eutrophic diatom is also a N-heterotroph because it may use organic forms of nitrogen for energy and growth. Melosira is considered a high quality food item for benthic macroinvertebrates because of its high nutrient and fatty acid content. This filamentous diatom has a morphology of relatively loosely connected cells that make it susceptible to removal by disturbance such as repeated scouring flows, high water velocity, or grazing by herbivorous benthic macroinvertebrates. Because of its tendency to fragment, Melosira does not tend to reach as high densities or biomass as other more resistant types (for example, Cladophora or Stigeoclonium) in disturbed habitats. 


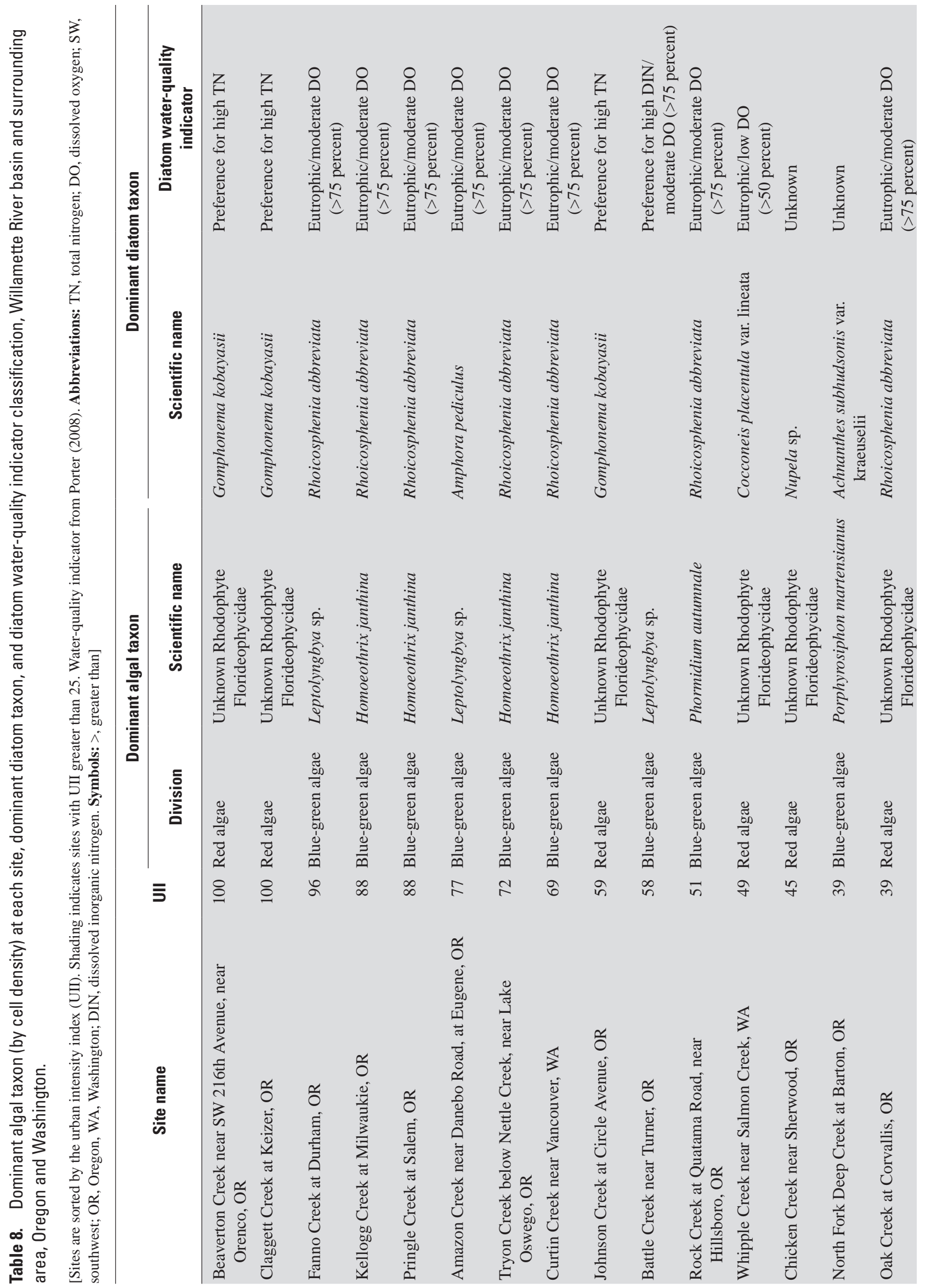




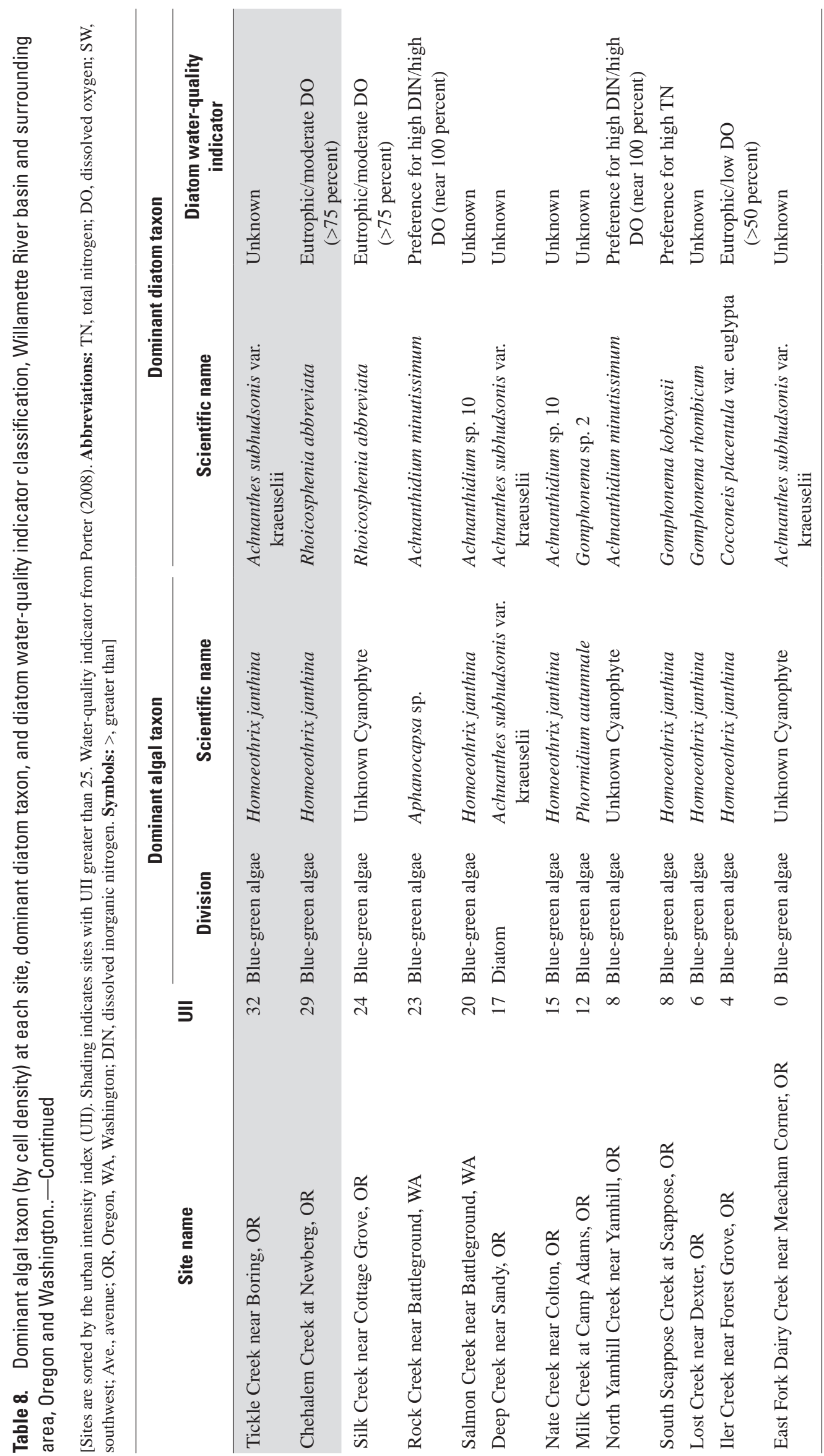



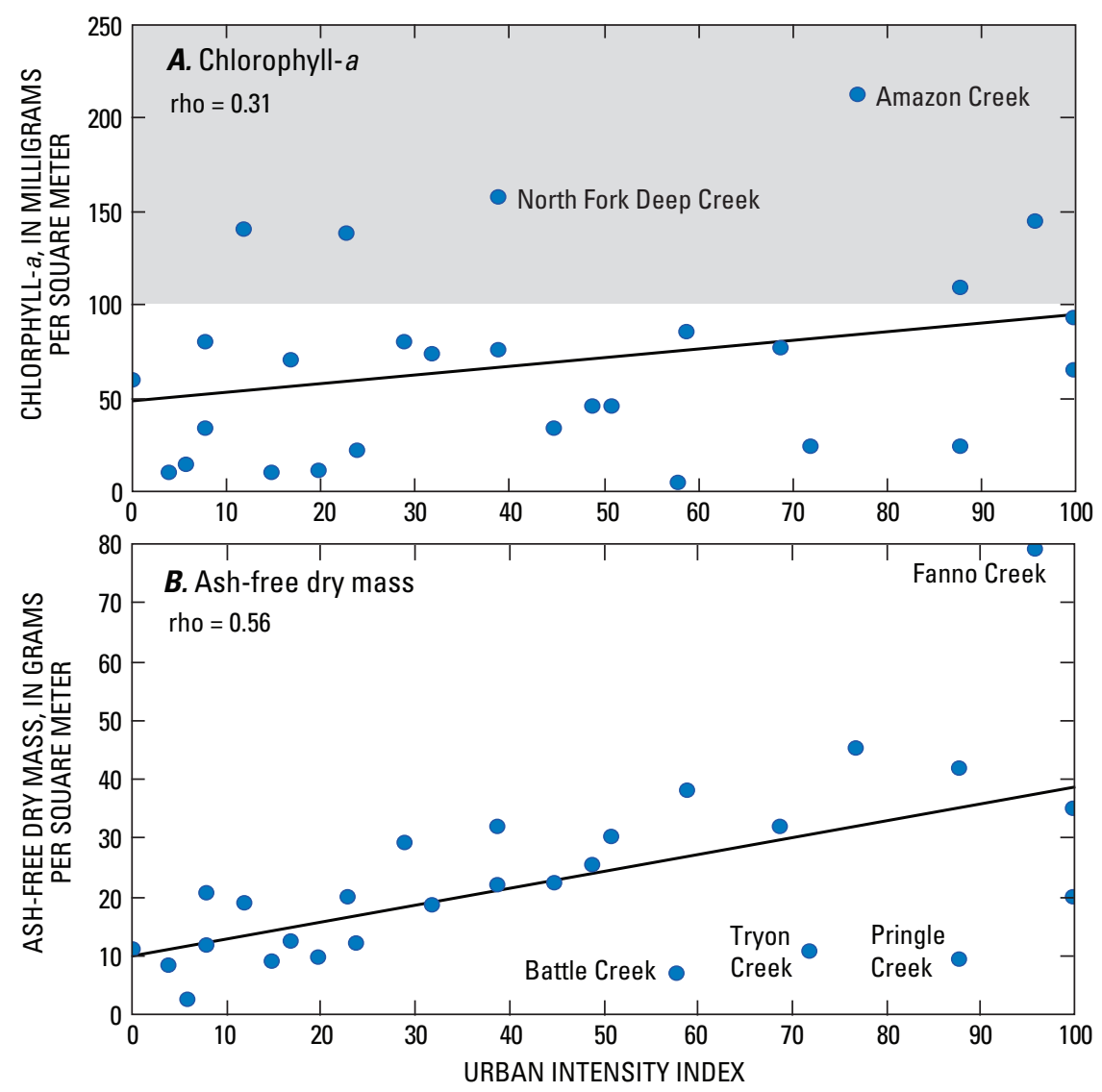

Figure 14. Relation between the urban intensity index (UII) and $(A)$ chlorophyll- $a$ and $(B)$ ash-free dry mass, Willamette River basin and surrounding area, Oregon and Washington. (Shading represents concentrations of chlorophyll-a greater than $\left.100 \mathrm{mg} / \mathrm{m}^{2}\right)$.

\section{Multivariate Analysis of Diatom Assemblages}

A number of environmental factors such as climate, geology, water-quality, habitat conditions, and anthropogenic disturbances (Biggs, 1990) can influence algal assemblages. In this study, diatom assemblage structure (axes scores from nMDS ordinations) were not significantly correlated (rho less than 0.2) to any of the urban indicators including road and population density, percentage of impervious area and urban land, or the UII. Additional multivariate analyses were conducted to identify which environmental variables (or combinations) explained the most variation in the diatom assemblage structure using the BEST routine in PRIMER. Variables included habitat parameters (water depth, velocity, and embeddedness), disturbance indicators (benthic macroinvertebrate grazers and a hydrologic variability index), light availability (open canopy), and water-quality measures (nutrients, DOC, $\mathrm{pH}, \mathrm{DO}$, and specific conductance). The best combination of variables-DOC, $\mathrm{pH}, \mathrm{Rb}$-flash and benthic macroinvertebrate scraper density-explained 68 percent of the variation in the diatom assemblage.
DOC, which was negatively correlated with DO (fig. 15), explained 44 percent of the variation in the diatoms assemblage structure among all sites. The highest individual rho values were those associated with habitat and channel hydraulics (percentage run habitat, Froude number, and maximum depth, rho $=0.47$; average substrate embeddedness, rho $=0.32$ ) and water chemistry (high-flow period specific conductance, rho $=0.43$; summer total phosphorus, rho $=$ 0.33 ; summer particulate nitrogen, rho $=0.33$; summer minimum water temperature, rho $=0.33$ ). Habitat and hydraulic conditions can alter the velocity regime for benthic algae, which can affect its overall growth form and profile (Hoagland and others, 1982), which is consistent with the influence of Froude number and Rb-flash on the diatom assemblage structure. In these streams, the higher amount of run habitat (and gradient) also might be contributing to higher sedimentation, leading to higher average substrate embeddedness. The water-quality variable with the highest rho value was specific conductance. Specific conductance often is used as a broad measure of anthropogenic influence, but is also affected by dilution (and watershed size), as well as 

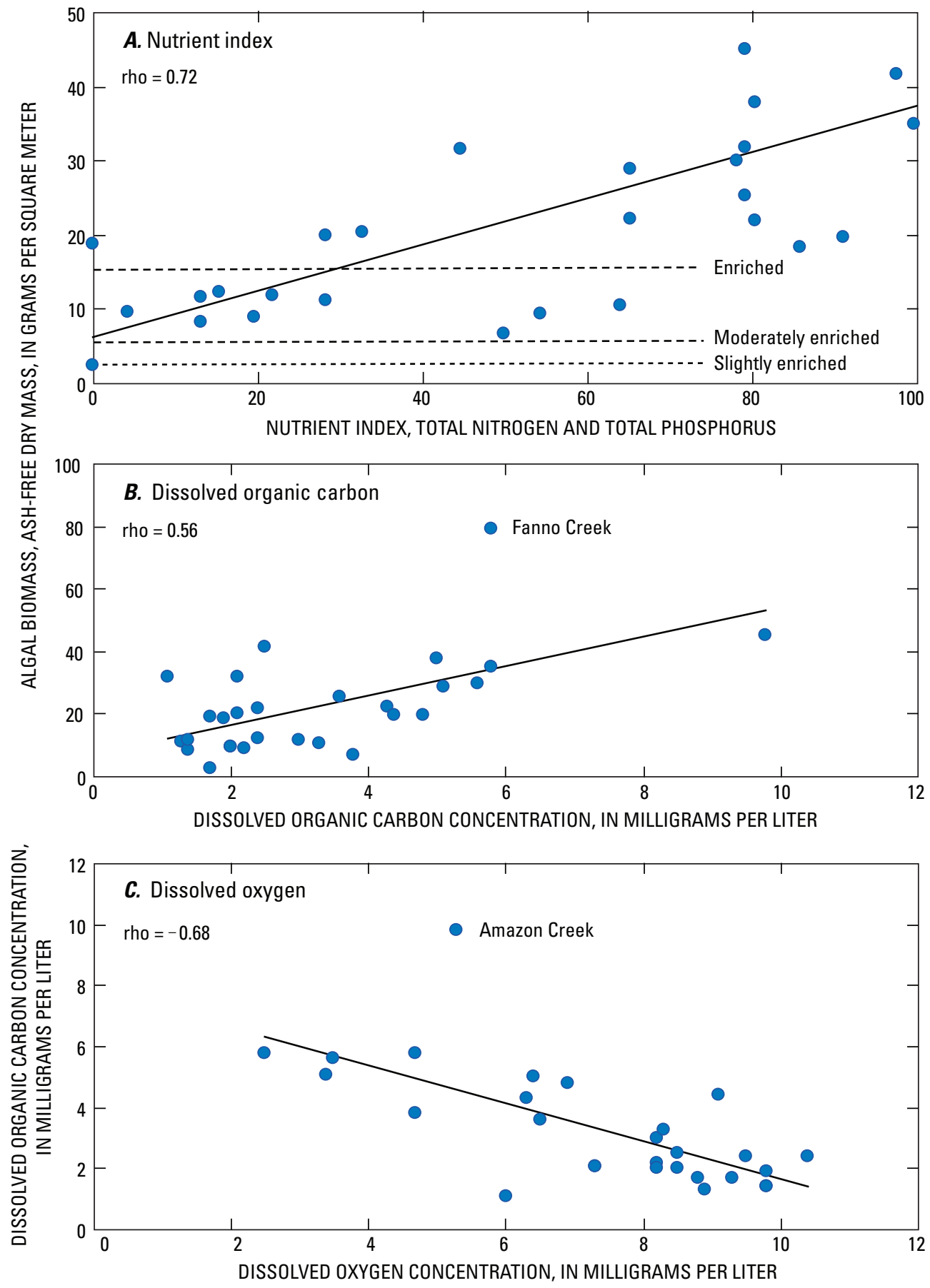

Figure 15. Relations between ash-free dry mass and $(A)$ nutrient index and $(B)$ concentrations of dissolved organic carbon, and $(C)$ dissolved organic carbon and concentrations of dissolved oxygen, Willamette River basin and surrounding area, Oregon and Washington.

natural factors such as soil and geology. Specific conductance has been shown to correlate well with algal assemblages in other studies in Oregon (Walker and Pan, 2006), other EUSE study areas (Potapova and others, 2005), and in Australia (Newall and Walsh, 2005). Correlations between specific conductance and anthropogenic influences can be stronger than nitrogen and phosphorus concentrations in streams with significant algal growths because of the nutrient uptake effect, which can lower nutrient levels substantially during periods of active growth. 


\section{Response in Algal Metrics to Urban Intensity Index and Select Environmental Variables}

Two algal metrics were correlated to the UII, including percentage of diatoms requiring high DO concentrations (nearly saturated) and, to a lesser degree, percentage of eutrophic (high-nutrient indicator) algae (fig. 16). Algal metrics also indicate that nutrient and sediment enrichment have measurable effects on the diatom assemblage structure in these streams, with eight metrics having significant correlations with either the UII or other environmental variable (table 9). The highest correlation coefficients (rho values) occurred between algal metrics and water-quality variables, including nutrients, DOC, and DO, and measures of algal biomass, especially AFMD (table 9).

The percentage of high-nutrient indicators (eutrophic diatoms) was strongly correlated to specific conductance $($ rho $=0.67)$ and moderately correlated to soluble reactive phosphorus (rho $=0.65)$, total phosphorus (rho $=0.55)$, and the nutrient index (rho $=0.52)$ (table 9). Another high-nutrient indicator metric (nitrogen heterotrophic taxa) - those that can use organic forms of nitrogen (organic nitrogen) - also were significantly correlated with concentrations of total nitrogen and total phosphorus (rho $=0.62$ and 0.69 , respectively) and algal biomass (AFDM: rho $=0.73$; chlorophyll- $a$ : rho $=0.69$ ) (table 9).
Algal metrics also showed the effects of depressed levels of DO in these streams that can result from bacterial respiration associated with decomposition of organic matter. For example, low-oxygen indicating taxa tolerant of depressed DO (10-30 percent saturation, or less [van Dam and others, 1994]) were positively correlated with total phosphorus (rho $=0.62)$, DOC (rho $=0.69)$, and benthic algal biomass $($ AFDM, rho $=0.63)$ (table 9$)$. In contrast, high oxygen indicator diatoms had negative correlations for most waterquality variables, particularly specific conductance and soluble reactive phosphorus (rho $=-0.74$ and -0.62 , respectively). Additionally, the percentage of taxa associated with high levels of organic enrichment ( $a$-mesosaprobic diatoms) was significantly correlated with concentrations of total phosphorus (organic nutrient: rho $=0.64)(\underline{\text { table } 9})$. These taxa tolerate depressed DO levels (10-70 percent saturation) and are associated with biological oxygen demand (BOD) levels of 4-22 mg/L (van Dam and others, 1994).

The percentage of diatoms tolerant of nutrient and organic pollution (Bahls, 1993) were similarly positively correlated to total phosphorus and total nitrogen concentrations (tolerant taxa: rho $=0.67$ and 0.71, respectively) and algal biomass (AFDM: rho $=0.66$; chlorophyll- $a$ : rho $=0.62$ ). The percentage of pollution sensitive diatoms, however, showed the opposite pattern and was negatively correlated with TP and TN (sensitive

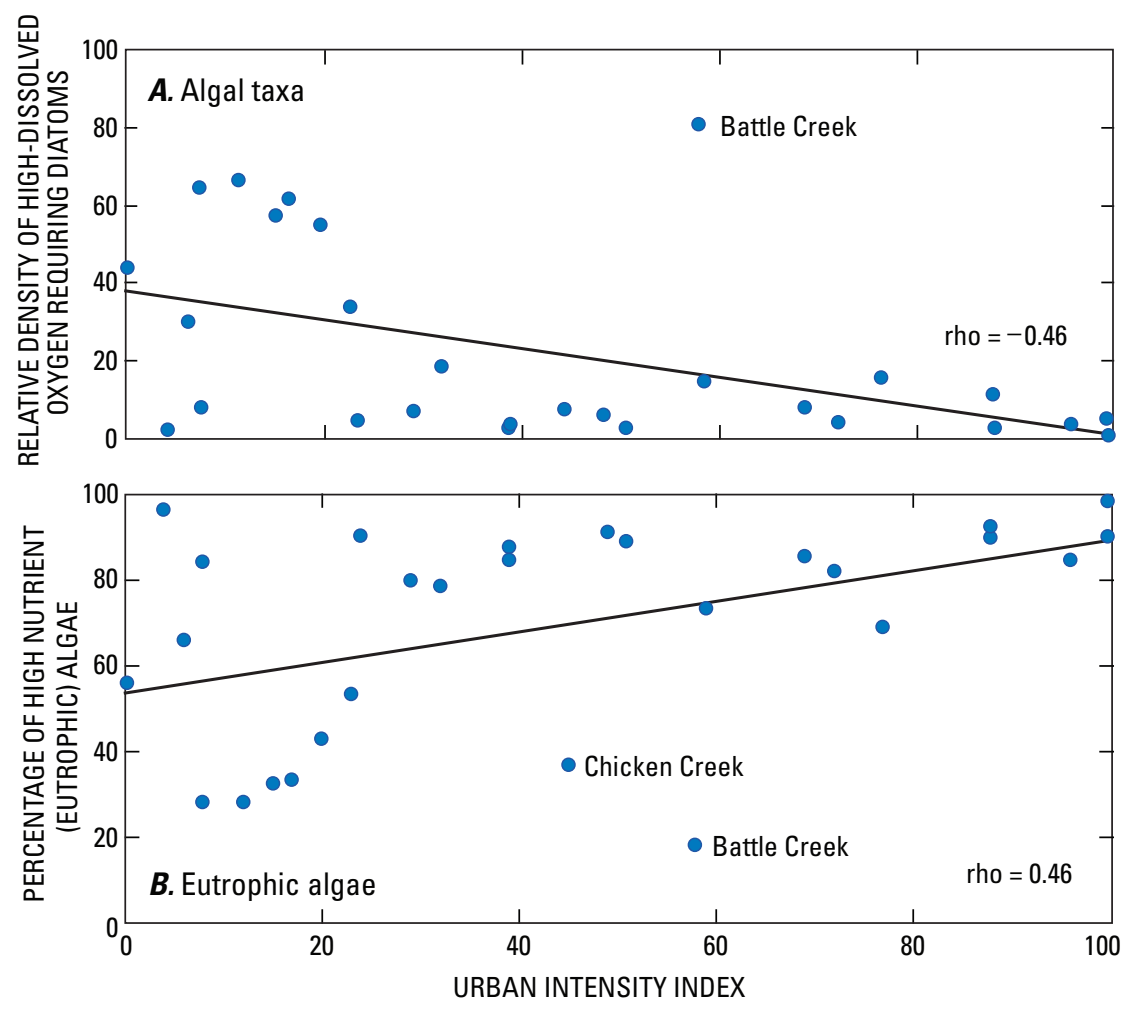

Figure 16. Relations between urban intensity index (UII) and (A) percentage of algal taxa requiring high levels of dissolved oxygen, and $(B)$ relative density of eutrophic algae, Willamette River basin and surrounding area, Oregon and Washington. 
Table 9. Spearman's rank correlation coefficients (rho values) between diatom algal metrics and the urban intensity index and select environmental variables, Willamette River basin and surrounding area, Oregon and Washington.

[See appendix A for definitions of environmental variables. Average concentrations were used for $\mathrm{TN}, \mathrm{NO}_{2}+\mathrm{NO}_{3}$, total phosphorus, soluble reactive phosphorus, specific conductance, $\mathrm{SO}_{4}$, and DOC. Correlation coefficients were considered strong when absolute value $\geq 0.66$ (bolded and shaded) and moderate when 0.66 $>r h o \geq 0.50$ (bolded). Nutrient, nitrogen, and oxygen taxa: van Dam and others (1994). High nutrient indicating (eutrophic) taxa require high nutrient levels. Nitrogen heterotrophs-taxa may use organic nutrient forms. High organic taxa- $\alpha$-meso/polysaprobous-taxa indicative of depressed dissolved oxygen levels (10-70 percent) and elevated biological oxygen demand (4-22 mg/L). Brackish water-taxa tolerate elevated levels of dissolved ions. Low oxygen-taxa tolerant of low dissolved oxygen levels. High oxygen-taxa require high dissolved oxygen levels. Pollution, Bahls (1993): tolerant-taxa generally tolerant of nutrient and organic enrichment; sensitive-taxa generally sensitive to nutrient and organic enrichment. Silt index: calculated by Sprouffske and others, 2006. Sum of motile Navicula and Nitzschia diatom taxa. Abbreviations: mg/L, milligram per liter; nd, no data]

\begin{tabular}{|c|c|c|c|c|c|c|c|c|}
\hline \multirow{2}{*}{ Environmental variables } & \multicolumn{8}{|c|}{ Diatom metric } \\
\hline & $\begin{array}{c}\text { Nutrient } \\
\text { (eutrophic) }\end{array}$ & $\begin{array}{c}\text { Organic } \\
\text { enrichment }\end{array}$ & $\begin{array}{l}\text { Organic } \\
\text { nitrogen }\end{array}$ & Low & High & $\begin{array}{c}\text { Tolerant } \\
\text { taxa }\end{array}$ & $\begin{array}{l}\text { Sensitive } \\
\text { taxa }\end{array}$ & $\begin{array}{l}\text { Silt } \\
\text { index }\end{array}$ \\
\hline Urban intensity index (UII) & 0.46 & 0.52 & 0.38 & 0.33 & -0.46 & 0.36 & -0.45 & 0.40 \\
\hline Total nitrogen $(\mathrm{TN})$ & .37 & .47 & .62 & .44 & -.27 & .71 & -.62 & .50 \\
\hline Soluble reactive phosphorus (SRP) & .65 & .44 & .57 & .42 & -.62 & .59 & -.51 & .62 \\
\hline Nutrient index & .52 & .54 & .65 & .52 & -.44 & .70 & -.63 & nd \\
\hline Specific conductance & .67 & .52 & .51 & .48 & -.74 & .50 & -.50 & .63 \\
\hline Summertime dissolved oxygen (DO) & -.20 & -.45 & -.27 & -.47 & .28 & -.36 & .46 & -.39 \\
\hline $\begin{array}{l}\text { Summertime minimum water } \\
\text { temperature }\end{array}$ & .41 & .53 & .51 & .51 & -.39 & .51 & -.61 & .52 \\
\hline Ash-free dry mass (AFDM) & .29 & .63 & .73 & .63 & -.31 & .66 & -.69 & .69 \\
\hline
\end{tabular}

taxa: rho values $=-0.68$; and -0.62 , respectively) and algal biomass (AFDM: rho $=-0.69$; chlorophyll- $a$ : rho $=-0.56$ ). Lastly, the Silt Index - the percentage of motile diatom genera Navicula and Nitzschia — was positively correlated with total phosphorus and AFDM (table 9). These organisms can thrive in streams affected by siltation because they can move out of the sediments to the surface where light levels are higher.

Taken together, the algal data show that diatom assemblages are affected by variations in streamflow, grazing by herbivorous benthic invertebrates, and processes relating to DOC (organic matter formation from excessive nutrients and high water temperature and decomposition, and subsequent effects of algal and bacterial metabolism on concentrations of DO). The positive correlation between benthic organic matter (AFDM) and the UII indicate that urbanization increases the amount of algae and other organic matter in streams through nutrient and (or) organic enrichment. DO is an important factor for important fish such as trout and salmon, which require relatively high levels of DO for survival and reproduction.

\section{Benthic Macroinvertebrate Assemblages}

One-hundred thirty-nine unique benthic macroinvertebrate taxa were identified in the $28 \mathrm{RTH}$ samples (table 10 and table A10). The most taxa (52) was for the insect order Diptera, with 37 from one dipteran family (Chironomidae), commonly known as midges. Diptera made up one-quarter of the total number of taxa collected, and had the highest taxa richness per family or order, by far. EPT orders-Ephemeroptera (mayflies), Plecoptera (stoneflies), and Trichoptera (caddisflies) had 13, 10, and 19 taxa per respective order. There were 12 taxa within the Coleoptera order (beetles), 2 taxa in Odonata (dragonflies and damselflies), and 1 each in Lepidoptera (butterflies and moths) and Megaloptera (dobsonflies). In addition to these insects, 29 noninsect taxa were spread among 17 orders, including snails, clams, aquatic worms, amphipods, and mites (table 10).

Only Simulium caadense (a dipteran blackfly) and Fluminicola (a gastropod snail) reached maximum singlesample abundances greater than 11,000 specimens per $\mathrm{m}^{2}$. 
Table 10. Number of benthic macroinvertebrate taxa and maximum abundance per insect order or noninsect group, Willamette River basin and surrounding area, Oregon and Washington.

[Abbreviation: $\mathrm{m}^{2}$, square meter]

\begin{tabular}{|c|c|c|c|}
\hline $\begin{array}{c}\text { Insect order/ } \\
\text { noninsect group }\end{array}$ & $\begin{array}{c}\text { Number } \\
\text { of unique } \\
\text { taxa }\end{array}$ & $\begin{array}{l}\text { Most } \\
\text { abundant } \\
\text { taxon }\end{array}$ & $\begin{array}{l}\text { Maximum } \\
\text { abundance } \\
\left(\mathrm{m}^{2}\right)\end{array}$ \\
\hline \multicolumn{4}{|c|}{ Insects } \\
\hline Ephemeroptera & 13 & Baetis tricaudatus & 3,082 \\
\hline Plecoptera & 10 & Zapada cinctipes & 4,081 \\
\hline Trichoptera & 19 & Cheumatopsyche sp. & 3,467 \\
\hline Diptera & 52 & Simulium canadense & 12,306 \\
\hline Chironomidae $^{1}$ & 37 & $\begin{array}{l}\text { Cricotopus } \\
\quad \text { bicinctus group }\end{array}$ & 3,303 \\
\hline Coleoptera & 12 & Optioservus sp. & 1,349 \\
\hline Lepidoptera & 1 & Lepidoptera & 64 \\
\hline Megaloptera & 1 & Sialis sp. & 40 \\
\hline Odonata & 2 & Gomphidae & 113 \\
\hline Total insects & 110 & & \\
\hline \multicolumn{4}{|c|}{ Noninsects } \\
\hline Amphipoda & 3 & Hyalella azteca & 1,401 \\
\hline Oligochaeta & 5 & Tubificidae & 2,129 \\
\hline Mollusca & 10 & Fluminicola sp. & 11,419 \\
\hline Other non-insects & 11 & Acari & 988 \\
\hline Total noninsects & 29 & & \\
\hline Total number of taxa & 139 & & \\
\hline
\end{tabular}

${ }^{1}$ The Chironomidae value is included in the Order Diptera and is not added for total insects.

Other major insect and noninsect orders had maximum abundances of between 1,300 and 4,100 specimens per sample. The noninsect Acari (Hydracarina, or water mites) and Simulium canadense (Diptera) were the most common taxa collected, occurring at 27 out of 28 sites (96 percentage occurrence; table 11), in addition, four of the top six most common taxa were other noninsects: Acari, Juga sp. (a snail), Dero sp. (Oligochaete worm), and Lumbriculidae (Oligochaete worm). Of the 22 taxa with at least 50 percent occurrence, 9 were noninsects, 6 were Diptera ( 5 chironomid midges and one blackfly, Simulium), 3 were Ephemeroptera, and 2 each were from Trichoptera and Coleoptera orders (table 11). Eighteen of these 22 taxa were considered moderately to highly tolerant of poor water-quality conditions, although 4 taxa (Paraleptophlebia sp., Zapada cinctipes, Rhithrogena sp., and Ceratopsyche cockerelli) were considered moderately to relatively sensitive.

\section{Benthic Macroinvertebrate Metrics in Relation to Urban Intensity Index}

The benthic macroinvertebrate metric "percent dominance" (percentage abundance of the maximum single taxon) has been considered a good bioindicator by some researchers (Barbour and others, 1999); however, in this and other recent studies, it does not correlate well with disturbance in this geographic region. In this study, percent dominance ranged from 14 percent to 67 percent, yet it only had a correlation to the UII of rho $=0.31$. However, the tolerance values of the single dominant taxa did show a good relation to the UII. A list of sites, sorted by UII (table 12), showed that the dominant taxa of the 17 sites with a UII greater than 25 had tolerance values between 7 and 10 (average 8), as determined by the USEPA tolerance scale (least to most tolerant -0 to 10 ). Additionally, those sites with UII greater than 25 had, on average, EPT richness of 4 taxa totaling 15 percent. On the other hand, sites with a UII less than 25 had tolerance values for their dominant taxa of between 3 and 8 (average 5), with much greater numbers of EPT taxa (average of 15 EPT taxa or a percent EPT richness of 44 percent). As a result, although percent dominance as a metric by itself did not correlate well to disturbance, interpreting ecological characteristics of the single dominant taxa among sites, such as USEPA tolerance values and optima, was useful (table 12). Looking at all sites instead of just the end members, there also was a strong negative correlation between EPT richness and UII (rho $=-0.75$; fig. 17) that reflects this large decrease in EPT taxa from the low to high urban sites.

Cuffney and others (2005) compared benthic macroinvertebrate metrics from three urban studies for two site groupings with different urban intensities: (1) most highly urban sites sampled (UII $\geq 70$ ) and (2) sites near reference condition (UII $\leq 10)$. They detected large differences between these two groupings in the richness and density of major benthic macroinvertebrate metrics including all taxa, EPT taxa only, Diptera, Chironomidae, and noninsects. Results from this study were similar, with an average increase of 12 EPT taxa and 32 percent EPT richness from the high urban group to the near reference condition group (table 13). However, unlike Cuffney and others (2005), who showed a large increase in total richness ( +25 taxa), we detected only a small increase in total taxa richness (an average increase of 5 taxa). In this study, the large increase in "EPT percent richness" was in addition to a large increase in average abundance of intolerant macroinvertebrates $(+3,848)$ and Ephemeroptera $(+3,111)$. There also was a large decrease in percentage of noninsect richness (-31 percent) and abundance of tolerant taxa ( -48 percent). Plecoptera are one of the most sensitive aquatic insect orders and, on average, almost no Plecoptera were detected at the highly urbanized sites, yet on 
Table 11. Commonly observed benthic macroinvertebrate taxa and tolerance values, Willamette River basin and surrounding area, Oregon and Washington.

[Taxa sorted in order of decreasing frequency of occurrence. Insect order and noninsect group: Taxa occurs in more than 50 percent of streams. Abbreviation: PNW, Pacific Northwest]

\begin{tabular}{|c|c|c|c|c|}
\hline $\begin{array}{l}\text { Insect order and } \\
\text { noninsect group }\end{array}$ & Taxa & $\begin{array}{l}\text { Number of } \\
\text { streams }\end{array}$ & $\begin{array}{l}\text { Percent of } \\
\text { sites }\end{array}$ & $\begin{array}{c}\text { PNW } \\
\text { tolerance } \\
\text { value }\end{array}$ \\
\hline Noninsect (water mite) & Acari & 27 & 96 & 6 \\
\hline Diptera & Simulium canadense & 27 & 96 & 6 \\
\hline Noninsect (snail) & Juga sp. & 25 & 89 & 7 \\
\hline Ephemeroptera & Baetis tricaudatus & 23 & 82 & 7 \\
\hline Noninsect (worm) & Dero sp. & 22 & 79 & 10 \\
\hline Noninsect (worm) & Lumbriculidae & 20 & 71 & 8 \\
\hline Trichoptera & Cheumatopsyche sp. & 19 & 68 & 8 \\
\hline Ephemeroptera & Paraleptophlebia sp. & 19 & 68 & 5 \\
\hline Diptera (Chironomidae) & Polypedilum sp. & 19 & 68 & 6 \\
\hline Diptera (Chironomidae) & Thienemannimyia group sp. & 17 & 61 & 6 \\
\hline Diptera (Chironomidae) & Rheotanytarsus sp. & 16 & 57 & 6 \\
\hline Diptera (Chironomidae) & Eukiefferiella sp. & 16 & 57 & 8 \\
\hline Diptera (Chironomidae) & Cricotopus bicinctus group & 16 & 57 & 7 \\
\hline Coleoptera & Optioservus sp. & 16 & 57 & 9 \\
\hline Coleoptera & Zapada cinctipes & 16 & 57 & 4 \\
\hline Noninsect (snail) & Ferrissia sp. & 16 & 57 & 7 \\
\hline Noninsect (amphipod) & Crangonyx sp. & 15 & 54 & 8 \\
\hline Noninsect (worm) & Tubificidae & 15 & 54 & 10 \\
\hline Noninsect (crayfish) & Pacifastacus leniusculus & 15 & 54 & 7 \\
\hline Noninsect (snail) & Fluminicola sp. & 15 & 54 & 7 \\
\hline Ephemeroptera & Rhithrogena sp. & 15 & 54 & 3 \\
\hline Trichoptera & Ceratopsyche cockerelli & 14 & 50 & 5 \\
\hline
\end{tabular}

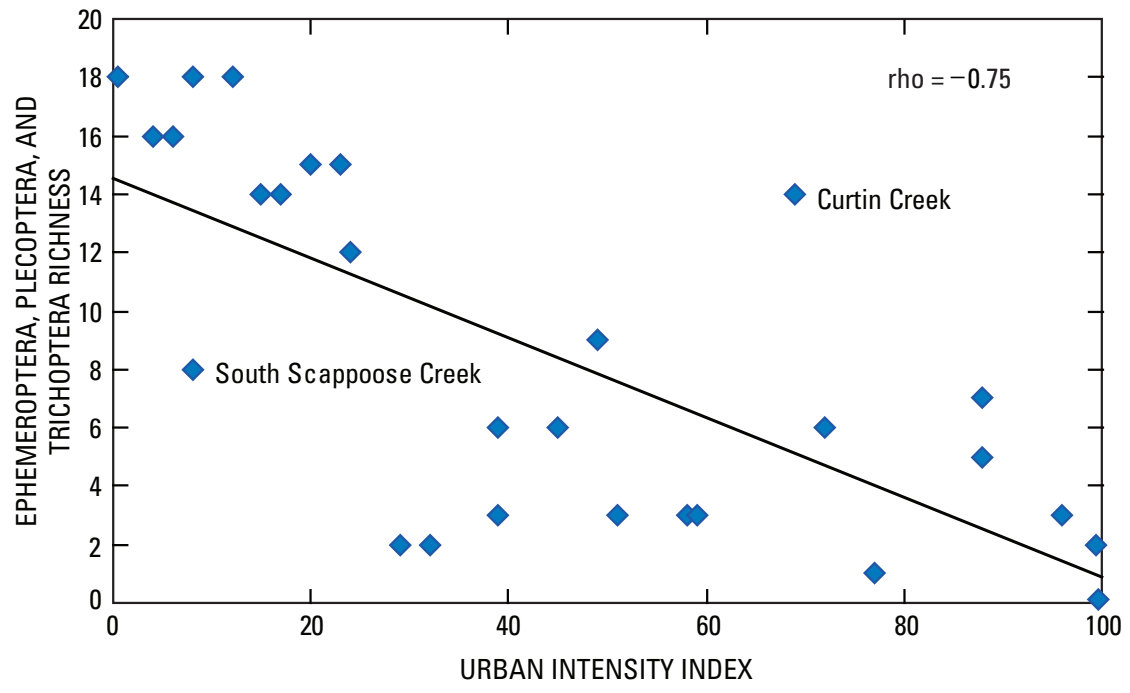

Figure 17. Relation between urban intensity index (UII) and number of benthic macroinvertebrate taxa (richness) in the Ephemeroptera, Plecoptera, and Trichoptera orders (EPT), Willamette River basin and surrounding area, Oregon and Washington. 
Table 12. Single dominant benthic macroinvertebrate taxon at each site, taxon name, U.S. Environmental Protection Agency tolerance value, Ephemeroptera, Plecoptera, and Trichoptera richness, and richness percentage per site, Willamette River basin and surrounding area, Oregon and Washington.

[Sites are sorted by the urban intensity index (UII). Shading indicates sites with UII greater than 25. Abbreviations: EPT, Ephemeroptera, Plecoptera, and Trichoptera; USEPA, U.S. Environmental Protection Agency; SW, southwest; OR, Oregon; WA, Washington]

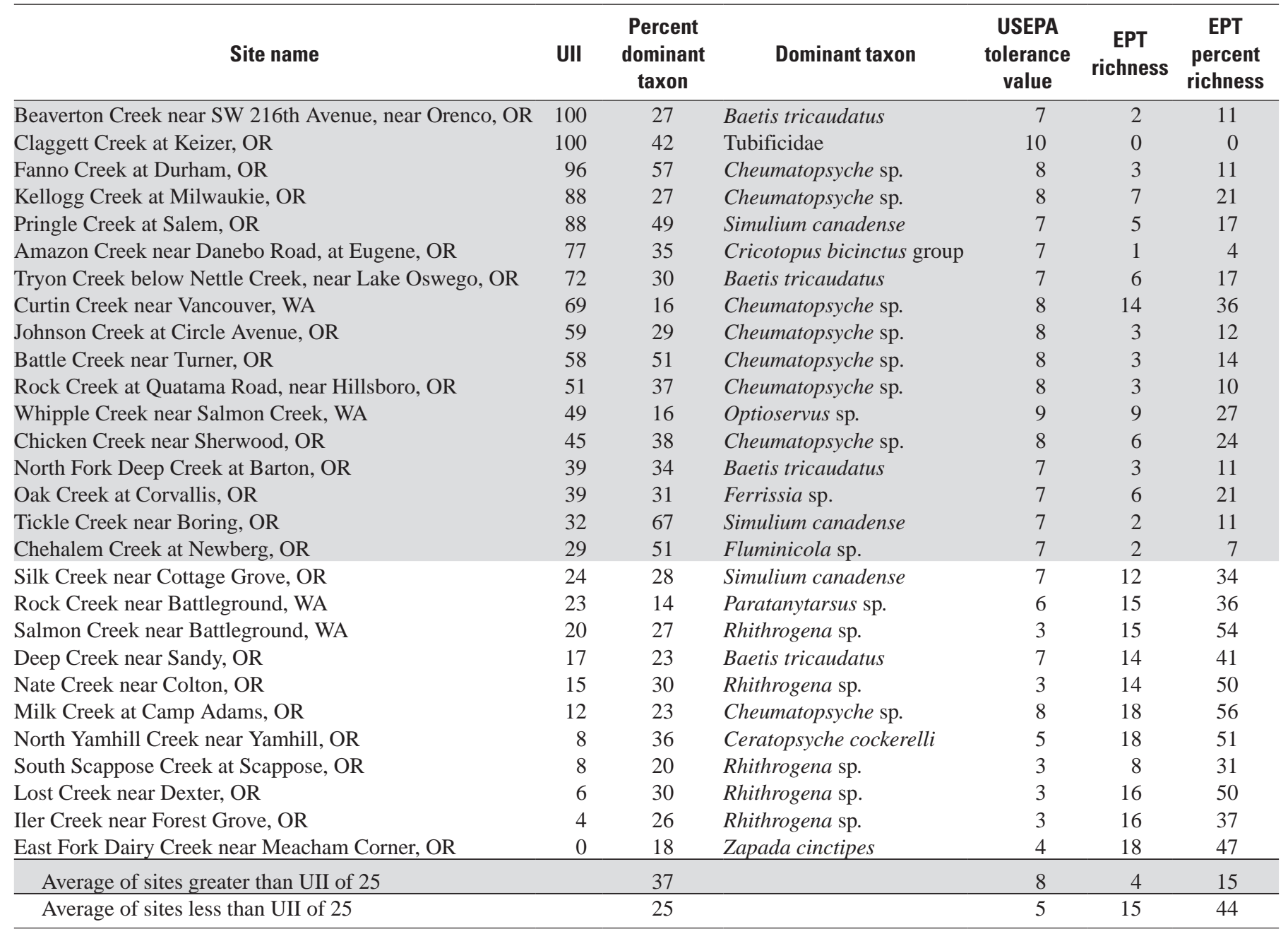

Table 13. Comparison of average benthic invertebrate abundance and richness metrics for high- and low-urban streams, Willamette River basin and surrounding area, Oregon and Washington.

[Abbreviations: UII, urban intensity index; EPEM, Ephemeroptera; PLECO, Plecoptera; EPT, Ephemeroptera, Plecoptera, and Trichoptera. Symbols: >, greater than; <, less than]

\begin{tabular}{|c|c|c|c|c|c|c|c|c|}
\hline $\begin{array}{l}\text { Urban intensity } \\
\text { index }\end{array}$ & $\begin{array}{c}\text { Total taxa } \\
\text { richness }\end{array}$ & $\begin{array}{c}\text { EPEM } \\
\text { abundance }\end{array}$ & $\begin{array}{c}\text { PLECO } \\
\text { percent } \\
\text { abundance }\end{array}$ & $\begin{array}{l}\text { EPT percent } \\
\text { richness }\end{array}$ & $\begin{array}{c}\text { EPT } \\
\text { richness }\end{array}$ & $\begin{array}{c}\text { Noninsect } \\
\text { percent } \\
\text { richness }\end{array}$ & $\begin{array}{l}\text { Intolerant } \\
\text { abundance }\end{array}$ & $\begin{array}{c}\text { Tolerant } \\
\text { percent } \\
\text { abundance }\end{array}$ \\
\hline $\mathrm{UII}>=70$ & 25 & 511 & 0 & 11 & 3 & 47 & 43 & 73 \\
\hline Difference & 5 & 3,111 & 14 & 32 & 12 & -31 & 3,848 & -48 \\
\hline
\end{tabular}


average, 14 percent abundance was detected at the sites near reference condition. Total taxa richness did not show a strong relation to urbanization in the Willamette Valley, even though richness of individual groups like EPT and noninsects had a strong relation to the UII. This indicates that there is specie replacement along the gradient, such that as sensitive EPT taxa drop out as urbanization increases noninsects and chironomid taxa take their place and total taxa richness remains relatively the same. Therefore, like the metric percent dominance mentioned previously, total taxa richness does not work well as a metric indicative of disturbance in this region even though it often is useful in other geographic regions.

Many benthic macroinvertebrate metrics had strong correlations to the UII. The three greatest rho values were for Ephemeroptera richness (negative), Plecoptera richness (negative), and the abundance of tolerant taxa (positive; table 14). Spearman correlation coefficients for these three benthic macroinvertebrate metrics and the five urban indicators were all greater than \pm 0.69 , with the strongest positive correlation between tolerant taxa and the UII (0.79) and the strongest negative between EPEM richness and POPDEN00 (-0.79; table 14). Many benthic macroinvertebrate metrics also had relatively strong correlation values with selected environmental setting metrics, including measures of soil erosion potential, elevation, precipitation, watershed slope, and percentage of low elevation flat land in the watershed (table 14). Urban and agricultural land use development follows the natural topography in the Willamette Valley; a higher percentage of development is in the flatter lowelevation valley and less in the higher elevation foothills. Cuffney and others (2005) determined strong correlations for similar environmental setting variables with benthic macroinvertebrate metrics, but only for the more mountainous Salt Lake City region and not for the Boston or Birmingham areas. In the Willamette River basin and surrounding area, a number of benthic macroinvertebrate metrics had their strongest correlation coefficients to water-chemistry metrics, such as TP, total insecticide and total pesticide concentration, PTI, TEQ, and the Pyrene Index. Most Spearman correlation coefficients between benthic macroinvertebrate richness metrics and the aforementioned water-chemistry metrics were greater than 0.70 (table 14). The four strongest correlations were between percent Diptera richness (not including chironomid midges) and the Pyrene Index $($ rho $=0.88)$ and the TEQ (0.85), and between percent richness of tolerant taxa and the TEQ (0.87), and between the EPT: Chironomid ratio and the total insecticide concentration $(-0.85$; table 14$)$. These strong correlation values between water-chemistry metrics and benthic macroinvertebrate metrics are similar to those published by Cuffney and others (2005), and indicate that one effect of pesticides and other potentially toxic compounds is a reduction in the number of sensitive insect taxa in favor of more tolerant chironomid midge larvae.
A shift in the benthic macroinvertebrate assemblage toward less palatable organisms such as worms (Oligochaetes), or snails potentially could affect fish assemblages. Any reduction in EPT insect abundance or taxa richness could have implications for salmonids and other fish in this region because EPT taxa are important contributors to aquatic food webs, linking algae with fish. EPT taxa include herbivorous caddisflies and mayflies, which play an important role in food webs by grazing algae. The EPT taxa typically emerge into flying adults in a chronologic sequence that lasts nearly year-round, in a pattern predictable to the local angler and resident fish. Reductions in EPT taxa could, reduce food available for fish that may lead to reductions in production or changes in species composition indirectly, in addition, stream conditions such as temperature, DO, or other factors that affect macroinvertebrates may also directly affect the natural fish assemblage.

\section{Multivariate Analysis of Benthic Macroinvertebrate Assemblages}

Ordination analysis took advantage of the full species assemblage at each site to determine patterns among sites based on the biological data. This approach provided a more complete picture compared to analysis of individual benthic macroinvertebrate metrics, which examined selected components of the assemblage. The first nMDS ordination axis scores summarizes the major variation among sites as revealed by the full benthic macroinvertebrate species data (see Methods: Data Reduction and Analysis for explanation of ordinations), the scores reveal how the sites spread in a 2-dimensional plot based on the species occurring at each site. Therefore, sites that plot close to each other are similar in species composition, whereas sites that plot far apart from one another are very different in species composition. The first ordination axis scores were negatively correlated to the UII with a consistent and fairly even distribution of points, whereas the percentage of low elevation flat land in the watershed, shown to have relatively high correlations only to a few invertebrate metrics, did not correlate as well (figs, $\underline{18 A}$ and $C$ ), nor did the points spread consistently over the range of ordination scores. The ordination axis scores on the other hand, also had strong correlations to many of the same water-quality parameters as did the individual metrics (fig. $\underline{18 B}$ ) and the correlation values were within a similar range as the metrics (TEQ; rho $=-0.87$; fig. $18 D$ ). The PRIMER BEST routine identified six variables-TEQ, sum of total pesticides, average embeddedness, DO or percent riffle habitat (surrogates for each other), 7-day average water temperature, and the UII or percentage of urban plus agricultural land (surrogates for each other)_-that explained about 65 percent of the variation in the benthic macroinvertebrate assemblages among all sites. 


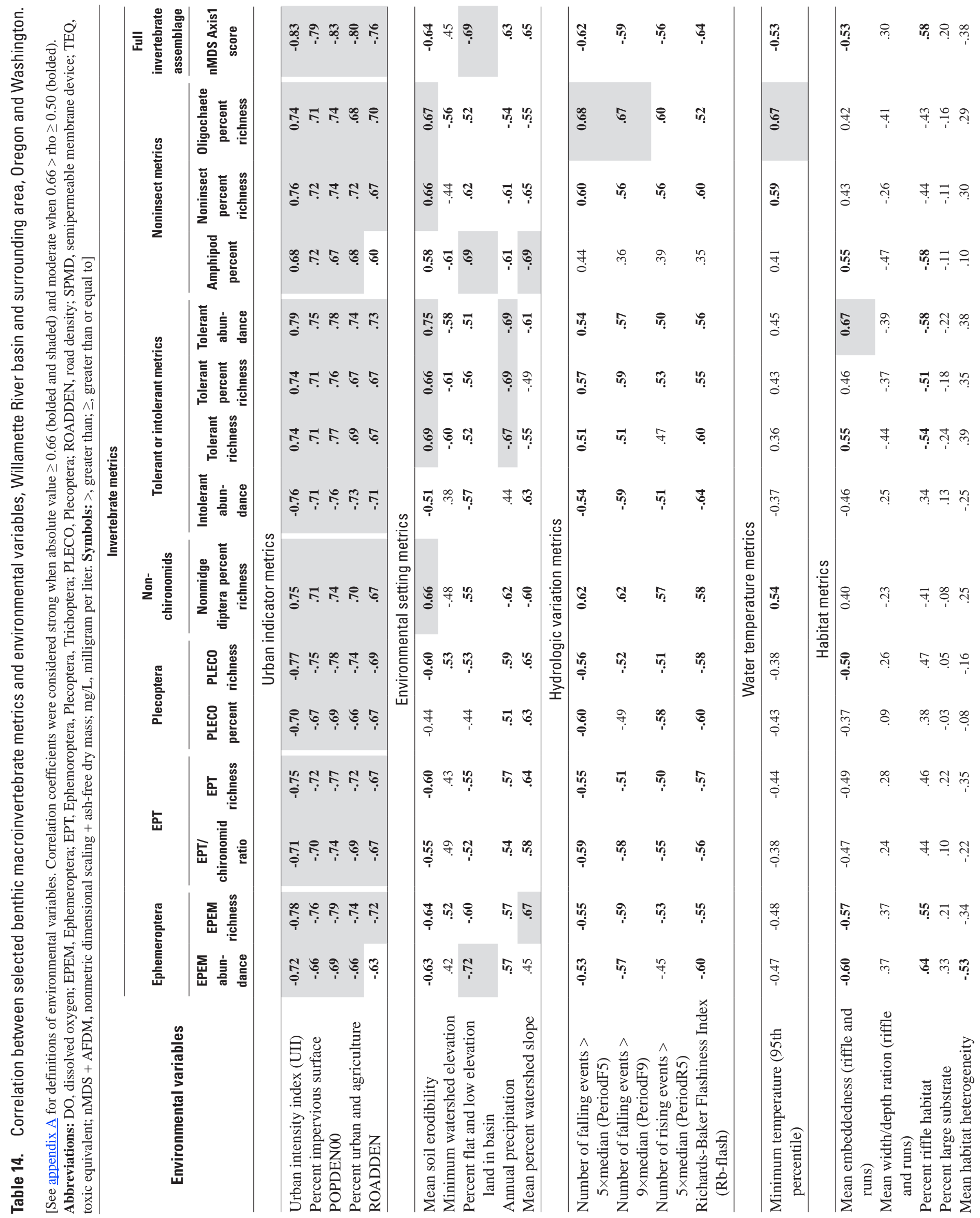




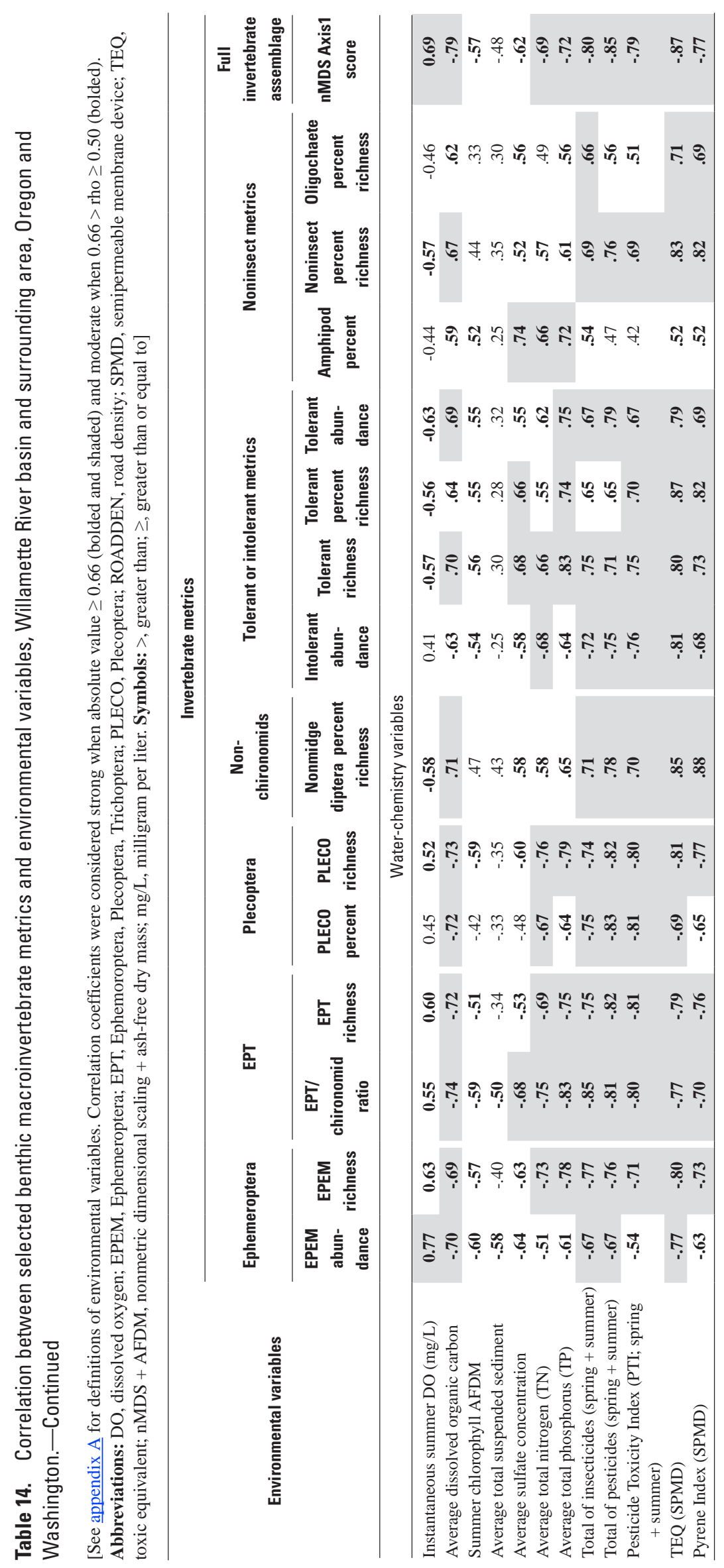



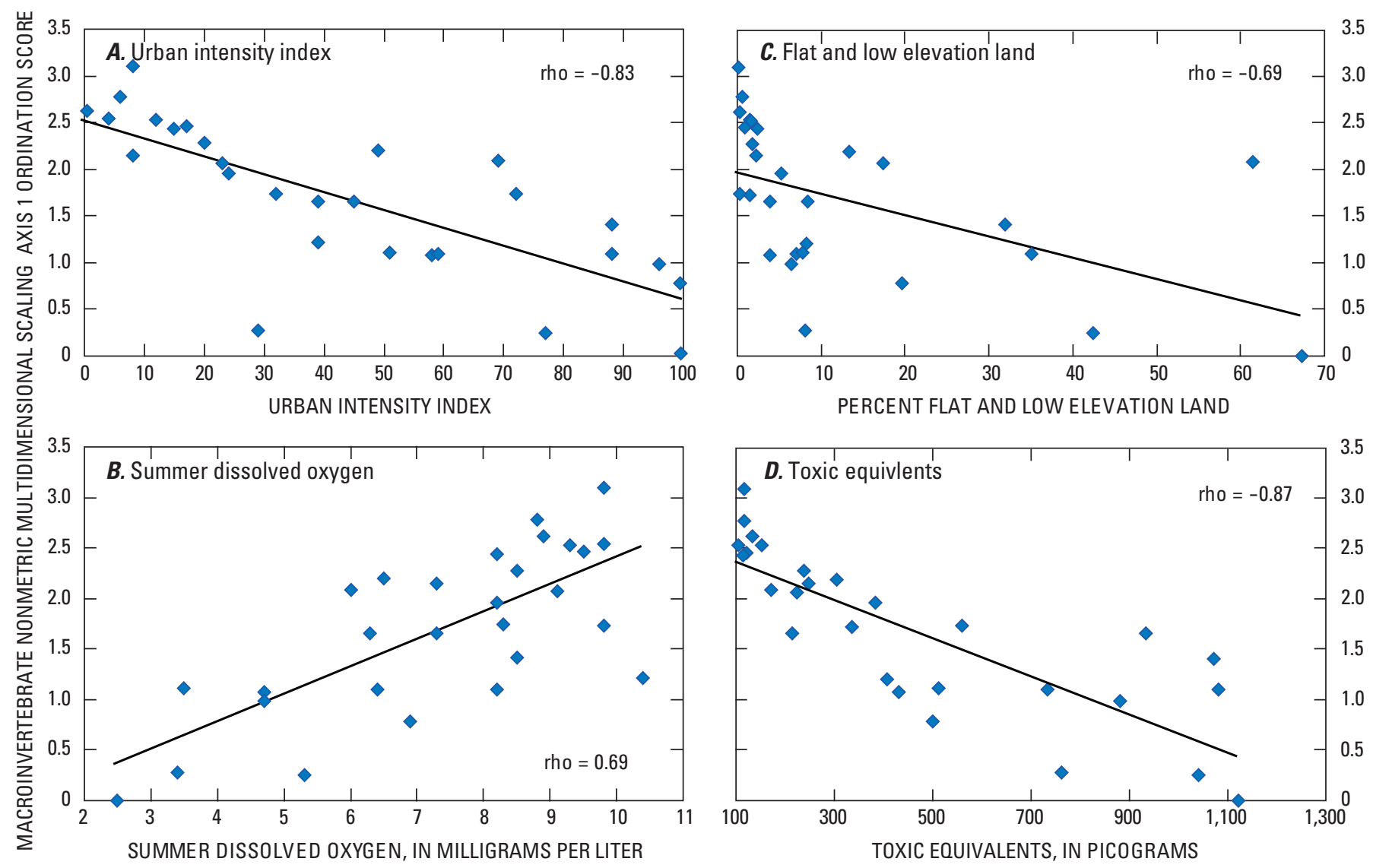

Figure 18. Benthic macroinvertebrate nonmetric dimensional scaling ordination axis 1 scores in relation to $(A)$ urban intensity index (UII), $(B)$ summer dissolved oxygen concentrations, $(C)$ percentage of flat and low elevation land in watershed and $(D)$ and toxic equivalents from semipermeable membrane devices, Willamette River basin and surrounding area, Oregon and Washington.

Although the first ordination axis used data from the complete benthic macroinvertebrate assemblage, the richness of EPT or Ephemeroptera metrics were strongly correlated with the nMDS axis score (rho greater than 0.90), which indicates that the first ordination axis largely described the same variation as the individual metrics, namely the change in richness of EPT or Ephemeroptera. This indicates that the disturbance gradient (UII) in the Willamette Valley was strong enough that differences among sites could be detected with only a part of the benthic macroinvertebrate assemblage. There is enough taxa diversity in the benthic macroinvertebrate data that part of the information is redundant. For example, EPT richness, a subset of the full species data set, could explain as much variation among sites as the full data (such as ordination axis).

Most benthic macroinvertebrate metrics showed linear responses to urbanization with no apparent threshold except, possibly, for EPT richness. EPT richness plotted against the UII showed a strong negative trend as urbanization increased and may have exhibited a threshold response near UII $=25$ (fig. 17). All sites less than UII 25 had greater than 12 or more EPT taxa (average 15) except for South Scappoose Creek, whereas all sites greater than UII 25 had less than 9 EPT taxa (average 4), except for Curtin Creek (table 12). South Scappoose Creek likely has a lower EPT richness because it is a low gradient stream with minimal riffle habitat with potentially more urban influence than reflected by the UII score. Conversely, Curtin Creek had a greater abundance of EPT taxa than other streams greater than UII 25 because it had cold, clear summer flows due to a large amount of groundwater discharge upstream of the sampling site, thus offering better water quality habitat than what the UII would suggest. In addition, no insecticides were detected in Curtin Creek (table 4) and it had low TEQ and Pyrene Index values. As a result, Curtin Creek had remarkable numbers of EPT taxa and low percent taxa dominance even with little in-stream habitat. Cuffney and others (2005) determined that responses of benthic macroinvertebrate metrics in the pilot USGS EUSE study areas generally were linear and without thresholds, except for a few selected metrics for the Boston-area. No thresholds or initial resistance to the effects of urbanization for full assemblage measures or ordination axes were detected in any region (Cuffney and others, 2005). 
Although there appeared to be a possible threshold in EPT richness at UII equal to 25, the apparent threshold was likely due to added agricultural land use in all sites greater than UII 25 than to any actual urban threshold. For example, at UII less than 25 the total percentage of urban plus agricultural land in the watershed was less than 16 percent (except for Deep Creek at 34 percent), yet immediately greater than a UII of 25, urban plus agricultural land increased markedly to between 53 and 98 percent (except for Oak Creek at 26 percent, table 1 and fig. 8). Therefore, any apparent threshold along the UII gradient was likely a threshold of the total of urban plus agricultural land use. However, the exact threshold is unknown because only two sites (Oak and Deep Creek) had urban plus agricultural land use percentages between 16 and 52 percent; therefore, there was not enough information in this data range to more fully evaluate thresholds. The plot of EPT richness and UII (fig. 17) indicates that if it exists, a threshold is at low values of urban plus agricultural land use, perhaps as low as 10 percent combined land use.

Although the streamflow, water temperature, and habitat measurements did not have as strong correlations as water-chemistry metrics to benthic macroinvertebrate metrics, they did have statistically significant values (greater than 0.60) for correlations of selected variables to a few metrics (table 14). The four hydrologic variables (PeriodF5, PeriodF9, PeriodR5 and Rb-flash) had correlations to a few benthic macroinvertebrate metrics greater than 0.60 . For habitat measures, correlation values were this strong only for percentages of riffle and embeddedness correlated with Ephemeroptera abundance and tolerant abundance. Water temperature had only one correlation to benthic macroinvertebrate metrics greater than 0.60 , with Oligochaete percent richness.

\section{Fish Assemblages}

\section{Fish Metrics in Relation to Urban Intensity Index}

Total fish richness ranged from 2 to 12 species, total abundance ranged from 52 to 672 , and maximum relative abundance or percent dominance of any single species ranged from 20 to 98 percent among all sites (table 15). Sixty percent of the sites had six species or fewer, yet there was no strong correlation of number of fish species to total abundance. For example, the site with the highest number of species (12) had a total abundance of 163 (North Fork Deep Creek) and the site with the lowest numbers of species (2) had an abundance of 380 (Tyron Creek). Western streams naturally have relatively low fish species richness compared to streams east of the Rocky Mountains (Simon and Lyons, 1995; Meador and others, 2005), and as a result, fish species richness from western streams generally have not been a good bioindicator. For example, a poor relation of fish species richness to UII was determined in this study, yet Meador and others (2005) determined a strong relation between fish species richness and urbanization in the Boston and Birmingham areas. On the other hand, nonnative or invasive species are a more serious problem in western than eastern streams and nonnative fish were in approximately 50 percent of sites greater than a UII of 25 , although only one occurrence was at a site less than 25 (table 15). Amazon Creek, with a UII of 77, contained the most nonnative species (five species) and highest percent abundance of nonnatives (98 percent) of any site. Claggett Creek, with a UII of 100, was the next highest with four nonnative species (19 percent abundance).

Although total species richness was not different between low and high UII sites, percentage of salmonids and nonnatives were different. Salmonids were present at 10 of 11 sites less than UII 25, whereas salmonids were present in only 4 of 17 sites greater than UII 25. No sites with salmonids had any nonnatives except one site, North Fork Deep Creek with 33 percent salmonids and 5 percent nonnatives. In this study, percent dominance (relative abundance) calculated from fish assemblage data had a strong curvilinear or possible threshold relation to the UII (rho $=0.67$ ) where low urban sites (less than UII 25; table 15) had low percent dominance (average of 46 percent), although sites greater than UII 25 had average dominance values greater than 80 percent (fig. 19). The threshold for percent dominance at UII of 25 was equivalent to about 3-5 percent impervious surface, which was lower than most other thresholds previously reported for fish community metrics (Lyons and others, 1996; Wang and others, 2001). The apparent urban threshold likely was due to added agricultural land use in sites greater than UII 25 and therefore the threshold likely represents the effect from total watershed disturbance of urban plus agricultural land use and not just urbanization.

The fish index, which combined individual metrics of percentages of salmonids, reticulate sculpins, nonnatives, and natives (with salmonids and reticulates removed), had high correlation values to urban indicators (UII: rho $=-0.68$; table 16). The fish index also was strongly correlated (rho greater than 0.60) to PeriodF5 hydrology, embeddedness, width-depth ratio, riffle percentage, summer DO, DOC, specific conductance, sulfate concentration, and TEQ (table 16). The highest correlation values were between percentage of salmonids and summer DO (rho $=-0.81)$ and percentage of riffle (rho $=-0.78)$. 
Table 15. Fish species richness, total abundance, percentages of dominance (single species), salmonids, and nonnative fish for 28 sites, Willamette River basin and surrounding area, Oregon and Washington.

[Sites are sorted by urban intensity index (UII). Shading indicates sites with UII greater than 25. Abbreviations: SW, southwest; OR, Oregon; WA, Washington]

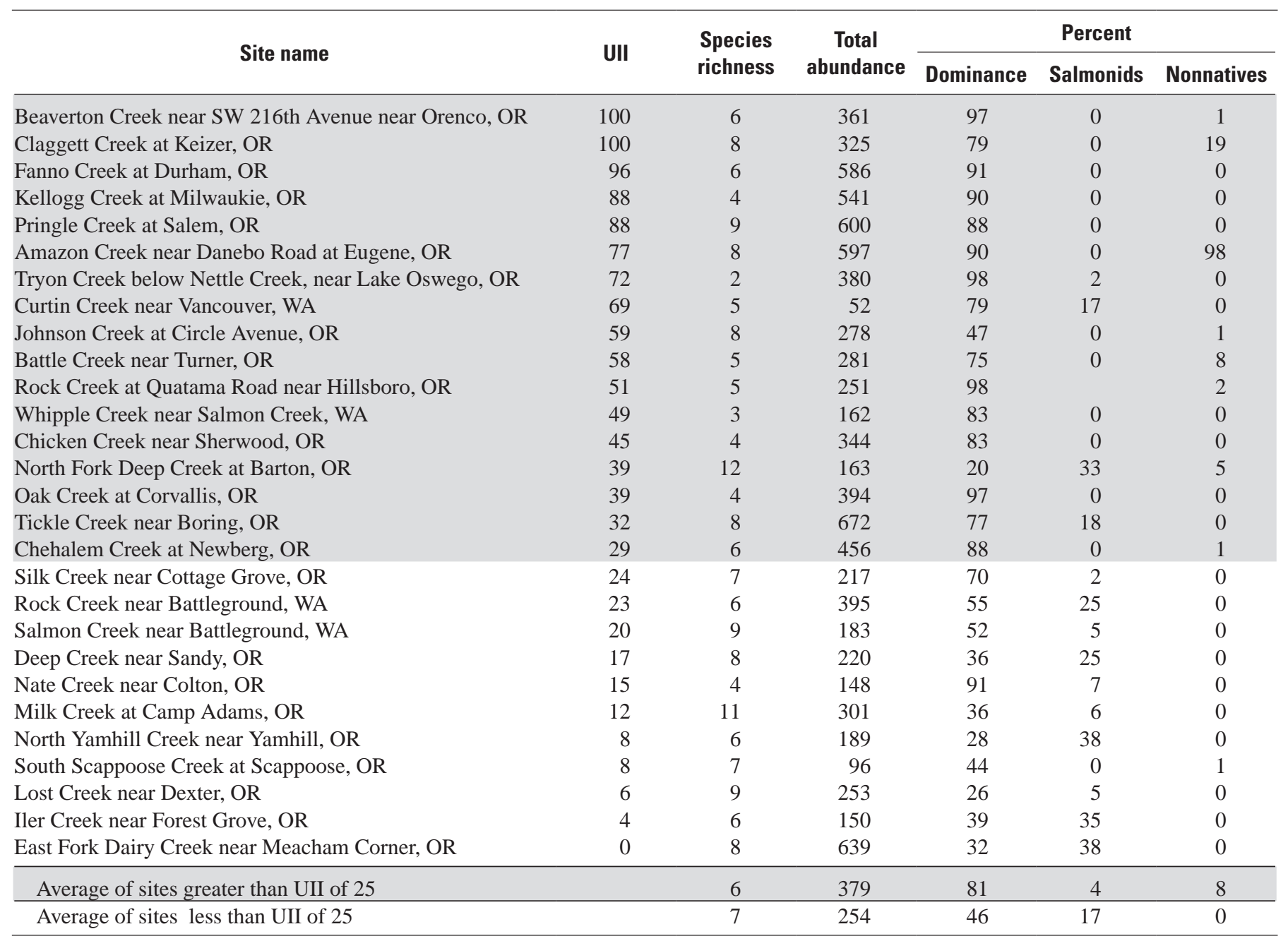

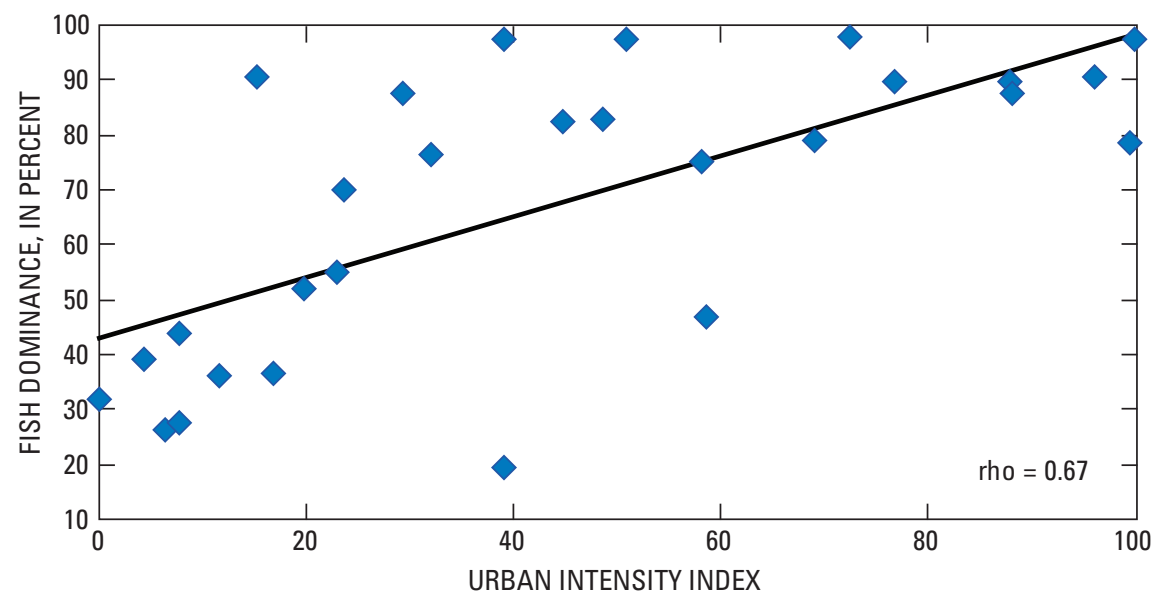

Figure 19. Relation between urban intensity index (UII) and percent dominance by single fish species at all 28 sites (highest relative abundance), Willamette River basin and surrounding area, Oregon and Washington. 
Table 16. Correlations of fish metrics and nonmetric dimensional scaling axis 1 ordination scores with environmental variables, Willamette River basin and surrounding area, Oregon and Washington.

[See appendix A for definitions of environmental variables. Correlation coefficients were considered strong when absolute value $\geq 0.66$ (bolded and shaded) and moderate when $0.66>r h o \geq 0.50$ (bolded). Abbreviations: DO, dissolved oxygen; TEQ, toxic equivalent index; SPMD, semipermeable membrane device; TN, total nitrogen; TP, total phosphorus; mg/L, milligram per liter. Symbols: >, greater than]

\begin{tabular}{|c|c|c|c|}
\hline Environmental variables & FISH Index & $\begin{array}{c}\text { Percent } \\
\text { salmonids }\end{array}$ & $\begin{array}{c}\text { FISH nMDS } \\
\text { Axis1 }\end{array}$ \\
\hline \multicolumn{4}{|c|}{ Urban indicator metrics } \\
\hline Urban intensity index (UII) & -0.68 & 0.62 & -0.76 \\
\hline Percent impervious surface & -.63 & .57 & -.69 \\
\hline POPDENOO & -.68 & .63 & -.75 \\
\hline Percent urban + agriculture & -.56 & .49 & -.68 \\
\hline ROADDEN & -.57 & .54 & -.69 \\
\hline \multicolumn{4}{|c|}{ Hydrologic variation metrics } \\
\hline Number of falling events $>5 \times$ median (PeriodF5) & -0.55 & 0.56 & -0.72 \\
\hline Number of falling events $>9 \times$ median (PeriodF9) & -.62 & .53 & -.63 \\
\hline Number of rising events $>5 \times$ median (PeriodR5) & -.48 & .48 & -.66 \\
\hline Richards-Baker Flashiness Index (Rb-flash) & -.53 & .53 & -.58 \\
\hline \multicolumn{4}{|c|}{ Habitat metrics } \\
\hline Mean embeddedness (riffle and runs) & -0.64 & 0.58 & -0.49 \\
\hline Mean width/depth ratio (riffle and runs) & .61 & -.53 & .37 \\
\hline Percent riffle habitat & .63 & -.78 & .67 \\
\hline Mean habitat heterogeneity & -.50 & .53 & -.53 \\
\hline \multicolumn{4}{|c|}{ Water temperature metrics } \\
\hline Seven day average temperature & -0.15 & 0.26 & -0.52 \\
\hline Minimum temperature (95th percentile) & -.50 & .60 & -.67 \\
\hline \multicolumn{4}{|c|}{ Water-chemistry variables } \\
\hline Summer dissolved oxygen (mg/L) & 0.70 & -0.81 & 0.77 \\
\hline Dissolved organic carbon & -.68 & .66 & -.74 \\
\hline Specific conductance & -.74 & .60 & -.53 \\
\hline Sulfate concentration & -.69 & .48 & -.50 \\
\hline Sum of total insecticides (TN) & -.59 & .46 & -.69 \\
\hline Sum of total pesticides (TP) & -.52 & .43 & -.70 \\
\hline TEQ (SPMD) & -.69 & .70 & .74 \\
\hline
\end{tabular}




\section{Multivariate Analysis of Fish Assemblages}

Bioindicators, such as ordination axis scores and individual metrics, were correlated against individual environmental variables to gain insight into what was structuring or potentially affecting the fish assemblages. The full fish assemblage, as represented by the scores of the first nMDS ordination axis, was negatively correlated to the UII with no apparent threshold (rho = -0.76; fig. 20A). With the exception of the percentage of salmonids metric (which had some high rho correlation values; table 16), the nMDS ordination axes scores had stronger correlations to the environmental variables than the fish index or individual metrics.

The relations between the ordination axis 1 scores and summer DO, TEQ, and PeriodF5 are shown in figures 20B-D. A strong linear response was noted in the fish assemblages along the UII and in response to DO concentrations. The response in the TEQ, however, may indicate a potential threshold between 300 and 500 picograms TEQ (fig. 20B). The axis 1 ordination scores also were strongly related to three hydrology variation metrics (PeriodF5; fig. 20D), percent riffle, minimum temperature, DOC, and sum of insecticides and pesticides (table 16). The BEST routine in PRIMER indicated that summer DO, percent riffles and PeriodF5 could explain about 60 percent of the variation in full fish assemblage data among the sites. The percentage of salmonids compared to the summer DO concentration may also be indicative of a possible threshold response (fig. 21). No salmonids were sampled at sites with midday summer DO concentrations less than $8 \mathrm{mg} / \mathrm{L}$, except at Curtin Creek. Because salmonids require cool waters with high DO to thrive, few were observed during the summer in these Willamette Valley ecoregion streams that often can have high summer temperatures with low dissolved oxygen. The Oregon Department of Environmental Quality standard for DO is $5.5 \mathrm{mg} / \mathrm{L}$ and 18 degrees Celsius (7-day moving average for the minimum summer water temperature). Curtin Creek was a unique site and although little high-quality fish habitat was within the sampled reach, it offered salmonids cold clear water during the summer with abundant instream habitat cover in the form of macrophytes and overhanging riparian vegetation. As a result, salmonids probably immigrated from nearby streams into Curtin Creek to take advantage of the cold water during summer.
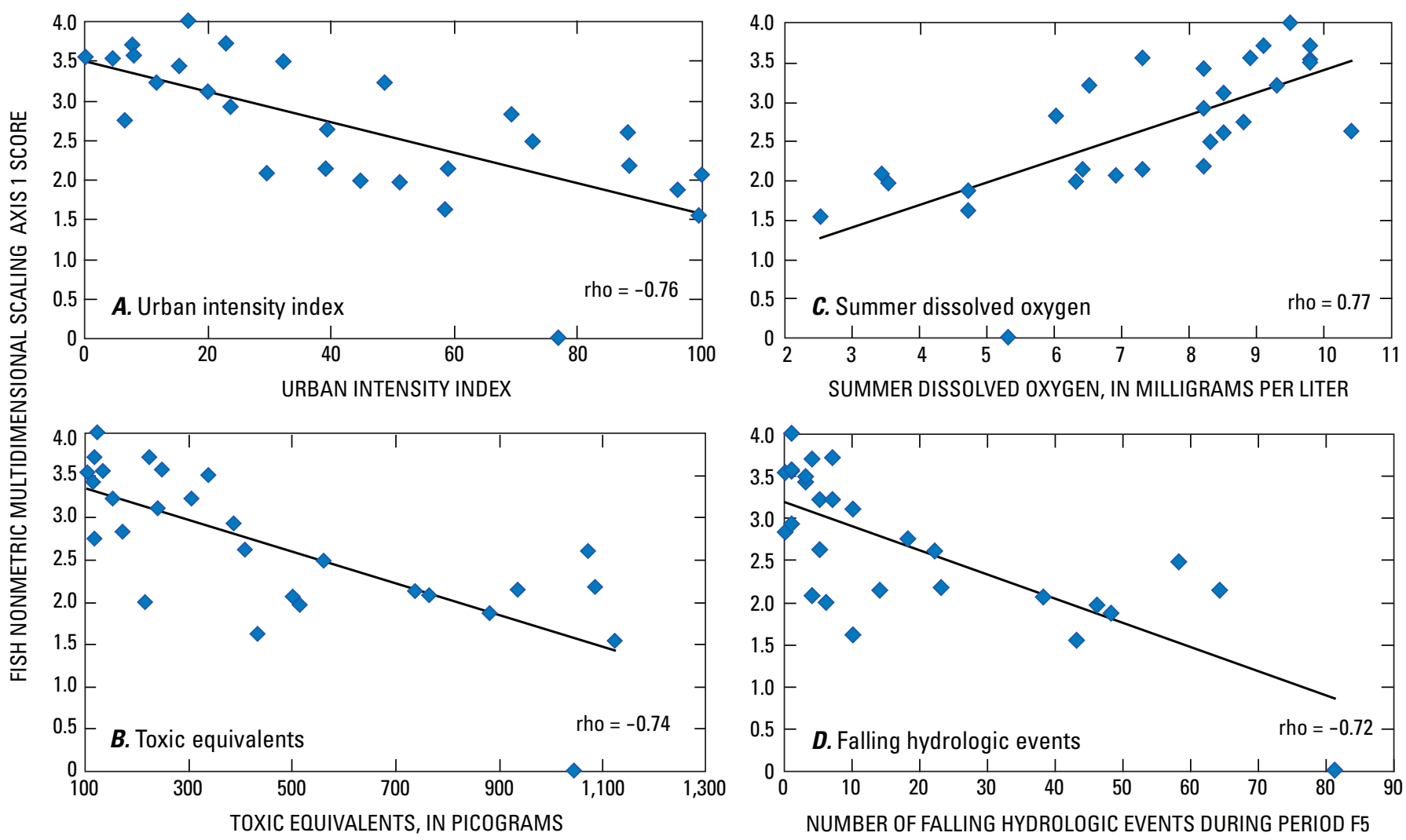

Figure 20. Relation between fish assemblages (nonmetric dimensional scaling first axis ordination scores) and $(A)$ urban intensity index (UII), (B) toxic equivalents (TEQ) from semipermeable membrane devices, (C) summer dissolved oxygen (DO) concentrations and $(D)$ the number of falling hydrologic events (PeriodF5), Willamette River basin and surrounding area, Oregon and Washington. 


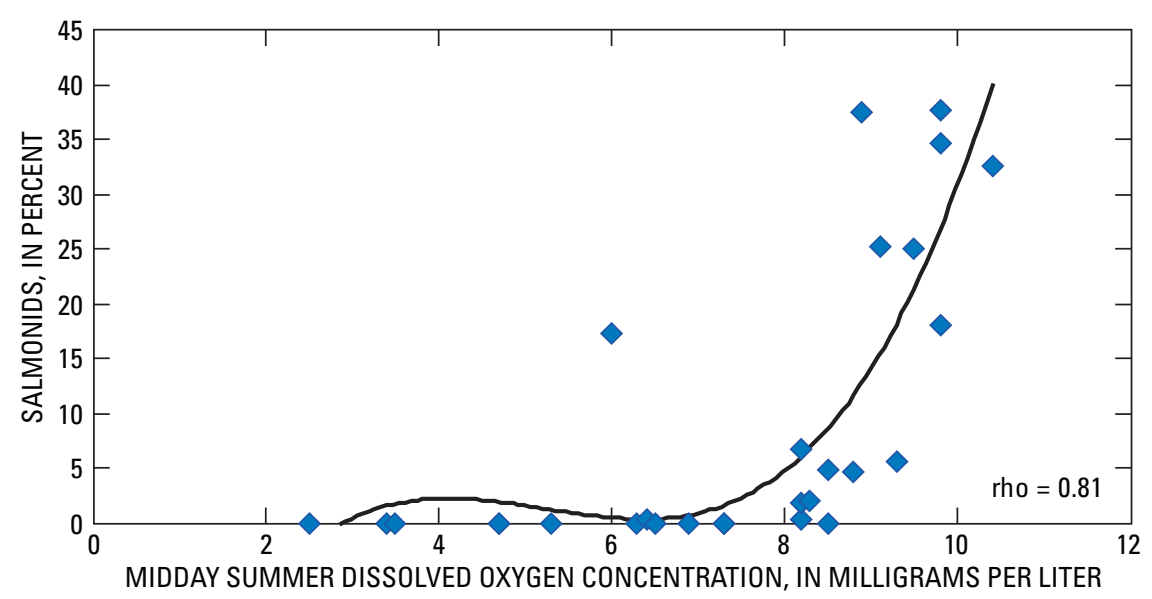

Figure 21. Relation between midday summer dissolved oxygen (D0) concentrations and percentage of salmonids, Willamette River basin and surrounding area, Oregon and Washington.
Most water-chemistry metrics, including sum total insecticide, sum total pesticide, pesticide toxicity index, toxic equivalents (TEQ), and Pyrene index, responded moderately to strongly to each increased urban indicator metric $(0.83 \geq$ rho $\geq 0.56$ ). For example, the sum of total insecticides correlated strongly to road density, population density, and the urban intensity index (rho $=0.73,0.70$, and 0.69 , respectively). However, insecticides were slightly less correlated to percentage of impervious surface and urban plus agricultural land use (rho $=0.66$ and 0.63 , respectively). Sum of total pesticides was strongly related to each urban metric (rho $\geq 0.66$ ), except percentage of impervious surface where it was moderate $($ rho $=0.65)$. The semipermeable membrane device assays correlated positively to urban

\section{Summary}

This study examined how urbanization affects stream ecosystems. Objectives of the study included an examination of physical, chemical, and biological responses to urbanization of small streams in the Willamette River basin and surrounding area, Oregon and Washington.

Hydrologic variable findings indicate that as urban intensity indicators increased (urban intensity index (UII), road density, percentage of impervious surface and population density), so did the stream flashiness. For example, the response of stream flashiness metrics to urbanization was moderate $(0.66>$ rho $\geq 0.50)$ to strong (rho $\geq 0.66)$ among the sites examined in this study. In addition, as urban indicators increased, minimum water temperature $\left(95^{\text {th }}\right.$ percentile $)$ also increased by a moderate response $(0.56 \geq$ rho $\geq 0.44)$. Other moderate responses to increased urbanization included an increase in average substrate embeddedness (riffles and runs), a decrease in average width-to-depth ratio (riffles and runs), and a decrease in the percentage of riffle habitat.

Physical data collected indicated that one of the strongest relations was detected between percentage of riffle habitat and summer dissolved oxygen concentrations ( rho $=0.84$ ). It was also discovered that there was a moderate to strong negative correlation of dissolved oxygen with minimum temperature, average substrate embeddedness, and mean habitat heterogeneity (measure of instream habitat diversity). There were other connections between physical and water chemistry, such as, streamflow flashiness metrics showed strong responses to select water-chemistry parameters, including dissolved organic carbon, sum of total pesticides, toxic equivalents (measure of water column contaminants obtained from semipermeable membrane devices), and sulfate concentration. Conversely, streamflow flashiness had a low correlation to nutrients, such as total nitrogen concentration $($ rho $=0.30)$. indictors as well, with toxic equivalents strongly associated to all urban indicator metrics $(0.81 \geq$ rho $\geq 0.73)$. The Pyrene index increased moderately to strongly with the increasing urban metrics $(0.67 \geq$ rho $\geq 0.51)$. Total nitrogen and total phosphorus both correlated strongly to the urban intensity index (rho $=0.79$ and 0.71 , respectively). Total nitrogen also correlated positively with the percentage of urban plus agricultural land use. Other water-chemistry metrics with strong correlations that increased with increasing urbanization were specific conductance and dissolved sulfate, whereas dissolved organic carbon, alkalinity, chloride, and summer dissolved oxygen were moderately correlated.

Algal assemblages responded to the nutrient and organic enrichment effects of urbanization (and agriculture at some sites), which included the development of nuisance green algae growths in some streams. For example, blue-green and red algae dominated the relative density in all but one stream, Deep Creek. High-nutrient indicator diatoms and other algal assemblages that tolerate moderate to high degrees of organic enrichment were positively correlated with the urban intensity index $(\mathrm{rho}=0.52)$.

Benthic algal chlorophyll- $a$ was highly variable along the urban gradient, but the ash-free dry mass (measure of algal biomass used to indicate the degree of organic enrichment) was positively correlated with the urban intensity index (rho $=0.56$ ). The ash-free dry mass was positively correlated with dissolved organic carbon concentrations, while dissolved oxygen was negatively correlated with dissolved organic carbon concentrations. These findings suggests that nutrient enrichment caused by urbanization increases the organic status of streams by stimulating algal growth and increasing ash-free dry mass. The organic matter eventually decomposes, which leads to the development of tolerant diatoms and heterotrophic algal taxa that make use of energy in the organic compounds. The use of such compounds by bacteria and other heterotrophic organisms consumes dissolved 
oxygen during respiration into carbon dioxide. Signs that this may be occurring in the more highly urbanized streams include the decrease in the relative abundance of diatom taxa requiring continuously high levels of dissolved oxygen. These sensitive taxa were most abundant at sites with a urban intensity index less than 25 , and less abundant at sites higher on the urban gradient. In addition to nutrients and other effects of eutrophication such as organic enrichment, other environmental factors that were determined to be important in shaping the diatom assemblages included various measures of disturbance, such as streamflow flashiness, channel scour, and grazing benthic macroinvertebrates.

Benthic macroinvertebrate assemblages also showed a strong response to urbanization. From the most urbanized sites (urban intensity index greater than 70) to the least urbanized (urban intensity index less than 10), there was an average decrease of 12 Ephemeroptera, Plecoptera and Trichoptera taxa detected. In addition, there was a large increase in percentage of noninsects (31 percent) and percentage of abundance of tolerant taxa (48 percent) between the range of urbanization. At the sites across the full urban gradient, many macroinvertebrate metrics had strong correlations to urban indicators and water-quality variables. For example, Ephemeroptera, Plecoptera and Trichoptera taxa richness $($ rho $=-0.75)$ and the nMDS ordination axis (rho $=-0.83$ ) were highly correlated to the urban intensity index. Macroinvertebrate metrics also had very strong correlations with total pesticide and insecticide concentrations, the pesticide toxicity index, contaminant measures from the semipermeable membrane device samples (TEQ and Pyrene Index), and summer dissolved oxygen. Although all four hydrologic variability and flashiness measures were moderately correlated to macroinvertebrate metrics, they represent less variation than any of the above waterquality variables. Therefore, although flashiness probably was an important issue in the urban areas of the Willamette River basin and surrounding areas, water chemistry issues including contaminants still are a dominant disturbance to macroinvertebrate assemblages followed by flashiness and sedimentation-substrate disturbance or habitat quality.

Fish assemblages showed strong correlation to urbanization, as well. For example, on average, 4 percent salmonids (sensitive) and 8 percent nonnative fish (tolerant) were found at sites with an urban intensity index greater than 25. Conversely, 17 percent salmonids and less than 1 percent nonnative fish were found at sites with an urban intensity index less than 25. All fish metrics, including fish index, salmonid percentage, and ordination axis 1 scores had strong correlations to the urban indicators and waterquality variables and moderate to strong correlation to the hydrologic variability, habitat, and water-temperature measures. Percentage of salmonids and macroinvertebrate Ephemeroptera, Plecoptera and Trichoptera taxa richness indicated a possible threshold response to urbanization at an urban intensity index of 25 , which was equivalent to impervious surfaces of about 5 percent. However, due to the added agricultural land use element at sites with urban intensity index values between 25 and 60, this threshold may not be due to urbanization solely, but a combination of urban and agricultural land uses. The effects of agricultural and urban land use could not be distinguished from each other, yet combined provide a good assessment of overall watershed health.

\section{Acknowledgments}

The authors would like to thank the dedicated U.S. Geological Survey field crew for their tireless efforts during the extended field season. We also would like to thank the Washington County Watermaster and Clark County Public Works for their superior maintenance of stream gage equipment. We thank the organizations and landowners who permitted us access to sites that made this study possible. We would also like to give special thanks to Lori Sprague of the U.S. Geological Survey in Denver, Colorado, for her guidance and direction for this report. Lastly, we thank Dennis Wentz and Cathy Tate of the U.S. Geological Survey, Rick Hafele of the Oregon Department of Environmental Quality, and Chris Prescott of the City of Portland, Bureau of Environmental Services for their reviews, which greatly improved this report.

\section{References Cited}

Alberti, M., and Marzluff, J.M., 2004, Ecological resilience in urban ecosystems-Linking urban patterns to human and ecological functions: Urban Ecosystems, v. 7, p. 241-265.

Anderson, C.W., Wood, T.M., and Morace, J.L., 1997, Distribution of dissolved pesticides and other waterquality constituents in small streams, and their relation to land use, in the Willamette River Basin, Oregon, 1996: U.S. Geological Survey Water-Resources Investigations Report 97-4268, 78 p.

Arar, E.J., and Collins, G.B., 1997, U.S. Environmental Protection Agency method 445.0, in vitro determination of chlorophyll- $a$ and pheophytin a in marine and freshwater algae by fluorescence, revision 1.2: Cincinnati, Ohio, U.S. Environmental Protection Agency, National Exposure Research Laboratory, Office of Research and Development, $22 \mathrm{p}$.

Arnold, C.L., and Gibbons, C.J., 1996, Impervious surface coverage-The emergence of a key environmental indicator: American Planners Association Journal, v. 62, p. 243-258.

Bahls, L.L., 1993, Periphyton bioassessment methods for Montana Streams: Helena, Mont., Water Quality Bureau, Department of Health and Environmental Sciences, 69 p. 
Baker, D.B., Richards, R.P., Loftus, T.T., and Kramer, J.W., 2004, A new Flashiness Index-Characteristics and applications to Midwestern rivers and streams: Journal of the American Water Resources Association, v. 40, no. 2, p. 503-522.

Barbour, M.T., Gerritsen, J., Snyder, B.D., and Stribling, J.B., 1999, Rapid bioassessment protocols for use in streams and wadeable rivers-Periphyton, benthic macroinvertebrates, and fish, (2d ed.): Washington, D.C., U.S. Environmental Protection Agency, Office of Water, EPA 841-B-99-002, $226 \mathrm{p}$.

Biggs, B.J., 1990, Periphyton communities and their environments in New Zealand rivers: New Zealand Journal of Marine and Freshwater Research, v. 24, p. 367-386.

Biggs, B.J., 1996, Patterns in benthic algae in streams, in Stevenson, J.R., Bothwell, M.L., and Lowe, R.L., eds., Algal ecology_Freshwater benthic ecosystems: San Diego, Calif., Academic Press Inc., p. 31-56.

Booth, D.B., and Jackson, C.R., 1997, Urbanization of aquatic systems-Degradation thresholds, stormwater detention, and the limits of mitigation: Journal of the American Water Resources Association, v. 22, no. 5, p. 1-20.

Britton, L.J., and Greeson, P.W., eds., 1987, Methods for collection and analyses of aquatic biological and microbiological samples: U.S. Geological Survey Techniques of Water-Resources Investigations, book 5, chap. A4, p. 139-140.

Brown, L.R., Gray, R.H., Hughes, R.M., and Meador, M.R., 2005, Introduction to effects of urbanization on stream ecosystems, in Brown, L.R., Hughes, R.M., Gray, R., and Meador, M.R., eds., Effects of urbanization on stream ecosystems: American Fisheries Society Symposium 47, p. 1-8.

Bryant, W.L., Goodbred, S.L., Leiker, T.L., Inuoye, Laura, and Johnson, B.T., 2007, Use of chemical analysis and assays of semi-permeable membrane devices extracts to assess the response of bioavailable organic pollutants in streams to urbanization in six metropolitan areas of the United States: U.S. Geological Survey Scientific Investigations Report 2007-5113, 46 p., 2 app., accessed May 17, 2007, at http://pubs.water.usgs.gov/sir2007-5113

Carpenter, K.D., 2003, Water-quality and algal conditions in the Clackamas River Basin, Oregon, and their relations to land and water management: U.S. Geological Survey Water-Resources Investigations Report 02-4189, 114 p.

Carpenter, K.D., and Waite, I.R., 2000, Relations of habitatspecific algal assemblages to land use and water chemistry in the Willamette Basin, Oregon: Environmental Monitoring and Assessment, v. 64, no. 1, p. 247-257.
Charles, D.F., Candia, K., and Davis, R.S., eds., 2002, Protocols for the analysis of the algae collected as part of the U.S. Geological Survey National Water-Quality Assessment Program: Academy of Natural Sciences Report 02-06, 124 p.

Clarke, K.R., and Ainsworth, M., 1993, A method of linking multivariate community structure to environmental variables: Marine Ecological Progress Series, v. 92, p. 205-219.

Clarke, K.R., and Gorley, R.N., 2006, PRIMER ver. 6-User manual: Plymouth Routines in Multivariate Ecological Research, PRIMER-E, Ltd., 190 p.

Coastal Change and Analysis Program (C-CAP), 2006, Pacific coast land cover-Oregon 2001 land cover data: National Oceanic and Atmospheric Administration, accessed March 2006 at http://www.csc.noaa.gov/crs/lca/pacificcoast.html

Cuffney, T.F., 2003, User's manual for the National WaterQuality Assessment Program Invertebrate Data Analysis System (IDAS) software-ver. 3: U.S. Geological Survey Open-File Report 03-172, 103 p.

Cuffney, T.F., Meador, M.R., Porter, S.D., and Gurtz, M.E., 2000, Responses of physical, chemical, and biological indicators of water quality to a gradient of agricultural land use in the Yakima River Basin, Washington: Environmental Monitoring and Assessment, v. 64, p. 259-270.

Cuffney, T.F., Zappia, H., Giddings, E.M.P., and Coles, J.F., 2005, Effects of urbanization on benthic macroinvertebrate assemblages in contrasting environmental settings-Boston, Massachusetts, Birmingham, Alabama, and Salt Lake City, Utah: American Fisheries Society Symposium 47, p. 361-408.

Davis, W.S., and Simon, T.P., eds., 1995, Biological assessment and criteria-Tools for water resource planning and decision making: Boca Raton, Fla., Lewis Publishers, $420 \mathrm{p}$.

Delwiche, L.D., and Slaughter, S.J., 1998, The little SAS book-A primer: Cary, N.C., SAS Institute Inc., 228 p.

Dodds, W.K., Jones, J.R., and Welch, E.B., 1998, Suggested classification of stream trophic state-Distributions of temperate stream types by chlorophyll, total nitrogen, and phosphorus: Water Research, v. 32, no. 5, p. 1455-1462.

Dodds, W.K., Smith, V.H., and Zander, B., 1997, Developing nutrient targets to control benthic chlorophyll levels in streams-A case study of the Clark Fork River: Water Resources Research, v. 31, no. 7, p. 1738-1750. 
Falcone, J.A., Stewart, J.S., Sobieszczyk, S., Dupree, J.A., McMahon, G., and Buell, G.R., 2007, A comparison of natural and urban characteristics and the development of Urban Intensity Indices across six geographic settings: U.S. Geological Survey Scientific Investigations Report 2007-5123, 133 p.

Fishman, M.J., 1993, Methods of analysis by the U.S. Geological Survey National Water-Quality LaboratoryDetermination of inorganic and organic constituents in water and fluvial sediments: U.S. Geological Survey Open-File Report 93-125, 217 p.

Fitzpatrick, F.A., Harris, M.A., Arnold, T.L., and Richards, K.D., 2004, Urbanization influences on aquatic communities in northeastern Illinois streams: Journal of the American Water Resources Association, v. 40, p. 461-475.

Fitzpatrick, F.A., Waite, I.R., D’Arconte, P.J., Meador, M.R., Maupin, M.A., and Gurtz, M.E., 1998, Revised methods for characterizing stream habitat in the National Water-Quality Assessment Program: U.S. Geological Survey WaterResources Investigations Report 98-4052, 67 p.

Gilliom, R.J., Barbash, J.E., Crawford, C.G., Hamilton, P.A., Martin, J.D., Nakagaki, N., Nowell, L.H., Scott, J.C., Stackelberg, P.E., Thelin, G.P., and Wolock, D.M., 2006, Pesticides in the nation's streams and ground-water, 1992-2001: U.S. Geological Survey Circular 1291, 172 p.

Greenspan Technology, 2006, Greenspan technology user manual, 7th ed., Greenspan Technology: accessed March 2006 at http://www.stevenswater.com/catalog/products/ water quality sensors/manual/Smart2-manual.pdf

Hoagland, K.D., Roemer, S.C., and Rosowski, R.R., 1982, Colonization and community structure of two periphyton assemblages with emphasis on the diatoms (Bacillariophyceae): American Journal of Botany, v. 69, p. 188-213.

Horner, R.R., Welch, E.B., and Veenstra, R.B., 1983, Development of nuisance periphytic algae in laboratory streams in relation to enrichment and velocity, in Wetzel, R.G., ed., Periphyton of freshwater ecosystems: Boston, Mass., Dr. W. Junk Publishers, p. 122-134.

Huckins, J.N., Manuweera, G.K., Petty, J.D., Mackay, D., and Lebo, J.A., 1993, Lipid-containing semi-permeable membrane devices for monitoring organic contaminants in water: Environmental Science and Technology, v. 27, p. 2489-2496.

Huckins, J.N., Tubergen, M.W., and Manuweera, G.K., 1990, Semi-permeable membrane devices containing model lipid-A new approach to monitoring the availability of lipophilic contaminants and estimating their bioconcentration potential: Chemosphere, v. 20, p. 533-552.
Jacobson, R.B., Femmer, S.R., McKenney, R.A., 2001, Land use changes and the physical habitat of streams-A review with emphasis on studies within the U.S. Geological Survey Federal-State cooperative program: U.S. Geological Survey Circular 1175, 63 p.

Johnson, B.T., 1998, Microtox toxicity test system-New developments and application, in Wells, P.G., Lee, K., and Blaise, C., eds., Microscale testing in aquatic toxicologyAdvances, techniques and practice: Boca Raton, Fla., CRC Lewis Publishers, p. 201-218.

Johnson, B.T., Petty, J.D., Huckins, J.N., Lee, K., and Gauthier, J., 2004, Hazard assessment of a simulated oil spill on intertidal areas of the St. Lawrence River with SPMD-TOX: Environmental Toxicology, v. 19, p. 329-335.

Konrad, C.P., and Booth, D.B., 2005, Hydrologic changes in urban streams and their ecological significance: American Fisheries Society Symposium 47, p. 157-178.

Koplin, D.W., Barbash, J.E., and Gilliom, R.J., 1998, Occurrence of pesticides in shallow ground-water of the United States-Initial results from the National WaterQuality Assessment Program: Environmental Science \& Technology, v. 32, no. 3, p. 558-566.

LeBlanc, R.T., Brown, R.D., and FitzGibbon, J.E., 1997, Modeling the effects of land use change on the water temperature in unregulated urban streams: Journal of Environmental Management, v. 49, p. 445-469.

Legendre, P., and Legendre, L., 1998, Numerical ecology 2d ed-Developments in Environmental Modeling 20: Amsterdam, The Netherlands, Elsevier Science, 853 p.

Lyons, J., Wang, L., and Simonson, T.D., 1996, Development and validation of an index of biotic integrity for coldwater streams in Wisconsin: North American Fish Management, v. 16, p. $241-256$.

McDonnell, M.J., and Pickett, S.T.A., 1990, Ecosystem structure and function along urban-rural gradients-An unexploited opportunity for ecology: Ecology, v. 71, p. 1231-1237.

McGarigal, Kevin, and Marks, B.J., 1995, FRAGSTATSSpatial pattern analysis program for quantifying landscape structure: U.S. Department of Agriculture Forest Service Technical Report PNW-352, 134 p.

McGarigal, Kevin, Cushman, S.A., Neel, M.C., and Ene, E., 2002, FRAGSTATS - Spatial pattern analysis program for categorical maps, FRAGSTATS 3.1: Amhurst, Mass., University of Massachusetts, accessed March 2006 at http:// www.umass.edu/landeco/research/fragstats/fragstats.html 
McMahon, G., Bales, J.D., Coles, J.F., Giddings, E.M.P., and Zappia, H., 2003, Use of stage data to characterize hydrologic conditions in an urbanizing environment: Journal of the American Water Resources Association, v. 39, no. 6, p. 1529-1546.

McMahon, G., and Cuffney, T.F., 2000, Quantifying urban intensity in drainage basins for assessing stream ecological conditions: Journal of the American Water Resources Association, v. 36, p. 1247-1261.

Meador, M.R., Coles, J.F., and Zappia, H., 2005, Fish assemblage responses to urban intensity gradients in contrasting metropolitan areas-Birmingham, Alabama and Boston, Massachusetts: American Fisheries Society Symposium 47, p. 409-423.

Moulton, S.R. II, Kennen, J.G., Goldstein, R.M., and Hambrook, J.A., 2002, Revised protocols for sampling algal, invertebrate and fish communities as part of the National Water-Quality Assessment Program: U.S. Geological Survey Open-File Report 02-150, 75 p.

Munn, M.D., and Gilliom, R.J., 2001, Pesticide toxicity index for freshwater aquatic organisms: U.S. Geological Survey Water-Resources Investigation Report 01-4077, 55 p.

Munn, M.D., Gilliom, R.J., Moran, P.W., and Nowell, L.H., 2006, Pesticide toxicity index for freshwater aquatic organisms (2d ed).: U.S. Geological Survey Scientific Investigations Report 2006-5148, $81 \mathrm{p}$.

Murk, A.J., Legler, J., Penison, M.S., Giesy, J.P., Vande Guchte, C., and Brouwer, A., 1996, Chemical activated luciferase gene expression, CALUX-A novel in vitro bioassay for $\mathrm{AH}$ receptor active compounds in sediment and pore water: Fundamental and Applied Toxicology, v. 33, p. 149-160.

Newall, P., and Walsh, C.J., 2005, Response of epilithic diatom assemblages to urbanization influences: Hydrobiologia, v. 532, p. 53-67.

Omernik, J.M., 1987, Ecoregions of the conterminous United States: Annals-Association of American Geographers, v. 77, no. 1, p. 118-125.

Paul, M.J., and Meyer, J.L., 2001, Streams in the urban landscape: Annual Review of Ecology and Systems, v. 32, p. 333-365.

Porter, S.D., 2008, Algal attributes-An autecological classification of algal taxa collected by the National WaterQuality Assessment Program: U.S. Geological Survey Data Series 329, http://pubs.usgs.gov/ds/ds329/.
Potapova, M., Coles, J.F., Giddings, E.M.P., and Zappia, H., 2005, A comparison of the influences of urbanization in contrasting environmental settings on stream benthic algal assemblages: American Fisheries Society Symposium 47, p. 333-359.

Roy, A.H., Freeman, M.C., Freeman, B.J., Wenger, S.J., Ensign, W.E., and Meyer, J.L., 2005, Investigating hydrologic alteration as a mechanism of fish assemblage shifts in urbanizing streams: Journal of the North American Benthological Society, v. 24, no. 3, p. 656-678.

Sala, O.E., Chapin, F.S. III, Armesto, J.J., Berlow, E., Bloomfield, J., Dirzo, R., Huber-Sanwald, E., Huenneke, L.F., Jackson, R.B., Kinzig, A., Leemans, R., Lodge, D.M., Mooney, H.A., Oesterheld, M., Poff, N.L., Sykes, M.T., Walker, B.H., Walker, M., and Wall, D.H., 2000, Global biodiversity scenarios for the year 2100: Science, v. 287, p. 1770-1774.

Sauer, V.B., 2002, Standards for the analysis and processing of surface-water data and information using electronic methods: U.S. Geological Survey Water-Resources Investigations Report 01-4044, 92 p.

Short, T.M., Giddings, E.M.P., Zappia, H., and Coles, J.F., 2005, Urbanization effects on habitat characteristics in Boston, Massachusetts; Birmingham, Alabama; and Salt Lake City, Utah: American Fisheries Society Symposium 47, p. 317-332.

Simon, T.P., and Lyons, J., 1995, Application of the index of biotic integrity to evaluate water resource integrity in freshwater ecosystems, in Davis, W.S., and Simon, T.P., eds., Biological assessment and criteria-Tools for water resource planning and decision making: Boca Raton, Fla., Lewis Publishers, p. 245-262.

Sinokrot, B.A., and Stefan, H.G., 1993, Stream temperature dynamics-Measurements and modeling: Water Resources Research, v. 29, p. 2299-2312.

Sprague, L.A., Zuelling, R.E., and Dupree, J.A., 2006, Effects of urbanization on stream ecosystems in the South Platte River Basin, Colorado and Wyoming: U.S. Geological Survey Scientific Investigations Report 2006-5101-A, $139 \mathrm{p}$.

Sprouffske, K., Mellott, D., Charles, D.F., and Potapova, M., 2006, Phyco-AIDE-Algal indicators and data exploration, ver. 2.0: Philadelphia, Pa., Academy of Natural Sciences, Phycology Section, Patrick Center for Environmental Research (computer program). 
Tate, C.M., Cuffney, T.F., McMahon, G., Giddings, E.M.P., Coles, J.F., and Zappia, H., 2005, Use of an urban intensity index to assess urban effects on streams in three contrasting environmental settings, in Brown, L.R., Hughes, R.M., Gray, R., and Meador, M.R., eds., Effects of urbanization on stream ecosystems: American Fisheries Society Symposium 47, p. 291-315.

Thorson, T.D., Bryce, S.A., Lammers, D.A., Woods, A.J., Omernik, J.M., Kagan, J., Pater, D.E., and Comstock, J.A., 2003, Ecoregions of Oregon (color poster with map, descriptive text, summary tables, and photographs): Reston, Va., U.S. Geological Survey (map scale 1:1,500,000), accessed March 2006 at http://www.epa.gov/wed/pages/ecoregions/or eco.htm

Uhrich, M.A., and Wentz, D.A., 1999, Environmental setting of the Willamette Basin, Oregon: U.S. Geological Survey Water-Resources Investigations Report 97-4082-A, 20 p.

U.S. Census Bureau, 2000, Census 2000 redistricting data summary file: U.S. Census Bureau Technical Documentation Public Law 94-171, 223 p.

U.S. Environmental Protection Agency, 2002, Envirofacts data warehouse: U.S. Environmental Protection Agency, accessed in 2002 at http://www.epa.gov/enviro/index_java. $\underline{\mathrm{html}}$

U.S. Environmental Protection Agency, 2002, Western ecology division, Level III ecoregions: U.S. Environmental Protection Agency, accessed in 2002 at http://www.epa.gov/ wed/pages/ecoregions/level iii.htm

U.S. Environmental Protection Agency, 2005, Western ecology division, Level IV ecoregions: U.S. Environmental Protection Agency, accessed in 2005 at http://www.epa.gov/wed/pages/ecoregions/level iv.htm

U.S. Geological Survey, (variously dated), National field manual for the collection of water-quality data: U.S. Geological Survey Techniques of Water-Resources Investigations, book 9, chaps. A1-A9, v. 2, (variously paged). Available at http://pubs.water.usgs.gov/twri9a

U.S. Geological Survey, 1999, National elevation dataset: U.S. Geological Survey Fact Sheet 148-99, accessed March 2006 at http://erg.usgs.gov/isb/pubs/factsheets/fs14899.html

U.S. Geological Survey, 2003, User's manual for the national water information system of the U.S. Geological Survey-Automated data processing system (ADAPS): U.S. Geological Survey Open-File Report 2003-123, 413 p.

U.S. Geological Survey, 2005, National land cover database 2001 (NLCD 2001): U.S. Geological Survey database, accessed December 2005 at http://www.mrlc.gov/mrlc2k $\underline{\text { nlcd.asp }}$
Van Dam, H., Mertens, A., and Sinkeldam, J., 1994, A coded checklist and ecological indicator values of freshwater diatoms from the Netherlands: Netherlands Journal of Equatic Ecology, v. 28, no. 1, p. 117-133.

Waite, I.R., and Carpenter, K.D., 2000, Associations among fish assemblage structure and environmental variables in Willamette Basin streams, Oregon: Transactions of the American Fisheries Society, v. 129, p. 754-770.

Walker, C.E., and Pan, Y., 2006, Using diatom assemblages to assess urban stream conditions: Hydrobiologia, v. 561, p. 179-189.

Walsh, C.J., Roy, A.H., Feminella, J.W., Cottingham, P.D., Groffman, P.M., and Morgan, R.P., 2005, The urban stream syndrome-Current knowledge and the search for a cure: Journal of the North American Benthological Society, v. 24, no. 3 , p. 706-723.

Walsh, C.J., Sharpe, A.K., Breen, P.F., and Sonneman, J.A., 2001, Effects of urbanization on streams of the Melbourne region, Victoria, Australia-I. Benthic macroinvertebrate communities: Freshwater Biology, v. 46, p. 535-551.

Wang, L.J., Lyons, J., Kanehl, P., and Bannerman, R., 2001, Impacts of urbanization on stream habitat and fish across multiple scales: Environmental Management, v. 28, p. 255-266.

Welch, E.B., Horner, R.R., and Patmont, C.R., 1989, Prediction of nuisance periphytic biomass-A management approach: Water Resources, v. 23, no. 4, p. 401-405.

Welch, E.B., Jacoby, J.M., Horner, R.R., and Seeley, M.R., 1988, Nuisance biomass levels of periphytic algae in streams: Hydrobiologia, v. 157, p. 161-168.

Winterbourne, M.J., and Townsend, C.R., 1991, Streams and rivers-One-way flow systems, in Barnes, R.S.K., and Mann, K.H., eds., Fundamentals of Aquatic Ecology: Oxford, England, Blackwell Science Ltd., p. 230-242.

Zaugg, S.D., Sandstrom, M.W., Smith, S.G., and Fehlberg, K.M., 1995, Methods of analysis by the U.S. Geological Survey National Water-Quality Laboratory-Determination of pesticides in water by $\mathrm{C}-18$ solid-phase extraction and capillary-column gas chromatography/mass spectrometry with selected-ion monitoring: U.S. Geological Survey Open-File Report 95-181, 60 p. 
Appendix A. Variable Definitions 
This page intentionally left blank. 


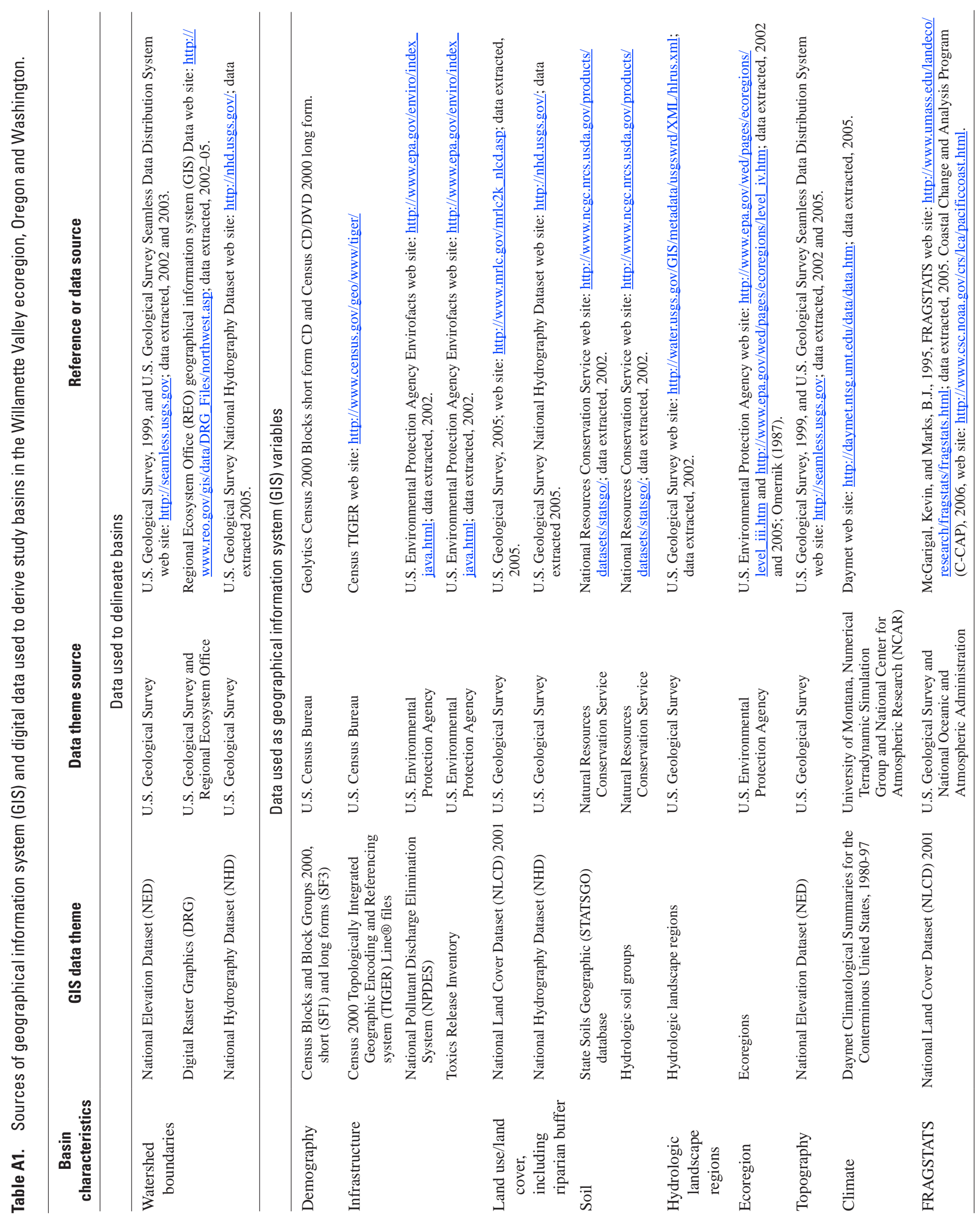


Table A2. Variables used to derive the final urban intensity index.

[Abbreviations: NLCD, National land cover data; $\mathrm{mi}$, mile; $\mathrm{mi}^{2}$, square mile]

\begin{tabular}{|c|c|c|}
\hline Variable code & Definition & $\begin{array}{c}\text { Spearmans' rho } \\
\text { correlation with } \\
\text { population density }\end{array}$ \\
\hline SEI_3 & $\begin{array}{l}\text { Socioeconomic Index 3: Principal component } 3 \text { for } 63 \text { socioeconomic variables ( } 2000 \text { census block- } \\
\text { group based) }\end{array}$ & 0.92 \\
\hline HHDEN & Household density (occupied housing units per square kilometer) (2000 census block-group based) & .99 \\
\hline PP_SH95 & Percentage of population living in same house as in 1995 (2000 census block-group based) & -.80 \\
\hline PHUT & $\begin{array}{l}\text { Percentage of occupied housing units using utility gas (natural gas) as fuel (2000 census block-group } \\
\text { based) }\end{array}$ & .78 \\
\hline PHLP & $\begin{array}{l}\text { Percentage of occupied housing units using liquid petroleum gas as fuel (2000 census block-group } \\
\text { based) }\end{array}$ & -.78 \\
\hline PHU_G60 & Proportion of housing units built prior to 1939 (2000 census block-group based) & -.73 \\
\hline PPASIA & Proportion of population of Asian ancestry (2000 census block-group based) & .74 \\
\hline \multicolumn{3}{|c|}{ NLCD 2000 Land Cover/Land Use Variables } \\
\hline pNLCD1_2 & Aggregated NLCD 2000 "level 1" category: developed (percentage of basin area) & 0.98 \\
\hline pNLCD1_3 & $\begin{array}{l}\text { Aggregated NLCD } 2000 \text { "level 1" category: barren (includes all level } 2 \text { barren and unconsolidated } \\
\text { categories) (percentage of basin area) }\end{array}$ & -.79 \\
\hline pNLCD1_4 & Aggregated NLCD 2000 "level 1" category: forest (percentage of basin area) & -.91 \\
\hline pNLCD1_5 & $\begin{array}{l}\text { Aggregated NLCD } 2000 \text { "level 1" category: shrubland (includes all level } 2 \text { shrub and scrub categories) } \\
\text { (percentage of basin area) }\end{array}$ & -.85 \\
\hline NLCD_BIS & NLCD 2000 mean percent impervious surface & .97 \\
\hline \multicolumn{3}{|c|}{ Infrastructure Variables } \\
\hline ROADDEN & Road density in watershed $=\left[\right.$ RDLENGTH $(\mathrm{mi}) /$ watershed area $\left.\left(\mathrm{mi}^{2}\right)\right]$ & 0.95 \\
\hline RDTRINDX & $\begin{array}{l}\text { Road traffic index in watershed (weighted miles): road traffic index } \mathrm{i}=\mathrm{SUM} \mathrm{j} \text { (length ij } * \text { Veh_Traffic } \\
\text { Wt ij) for watershed I and CFCC TIGER code } \mathrm{j}\end{array}$ & .73 \\
\hline
\end{tabular}


Table A3. Watershed variables used in data analysis.

[See table A1 for data sources. Abbreviations: $\mathrm{m}$, meter, $\mathrm{km}^{2}$, square kilometer; $\mathrm{cm}$, centimeter]

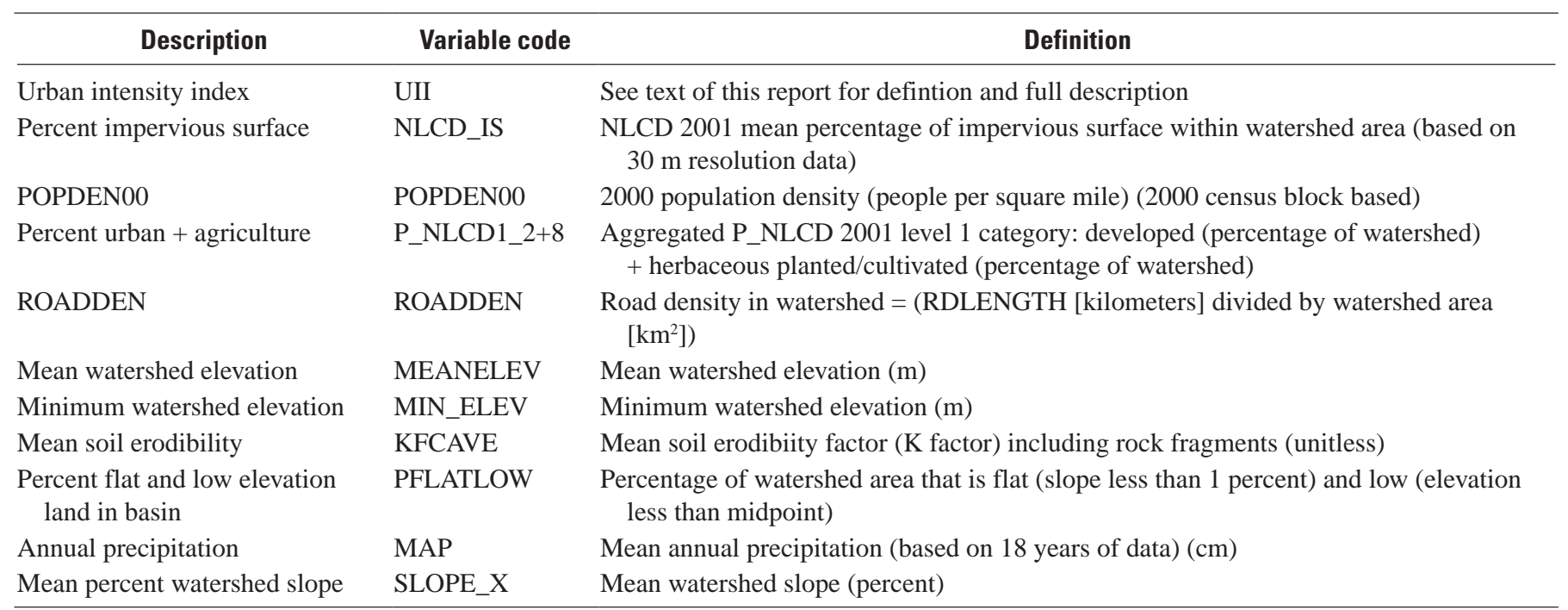

Table A4. Reach-scale habitat variables.

[Abbreviations: mm, millimeter; CV, coefficient of variance. Symbol: >, greater than]

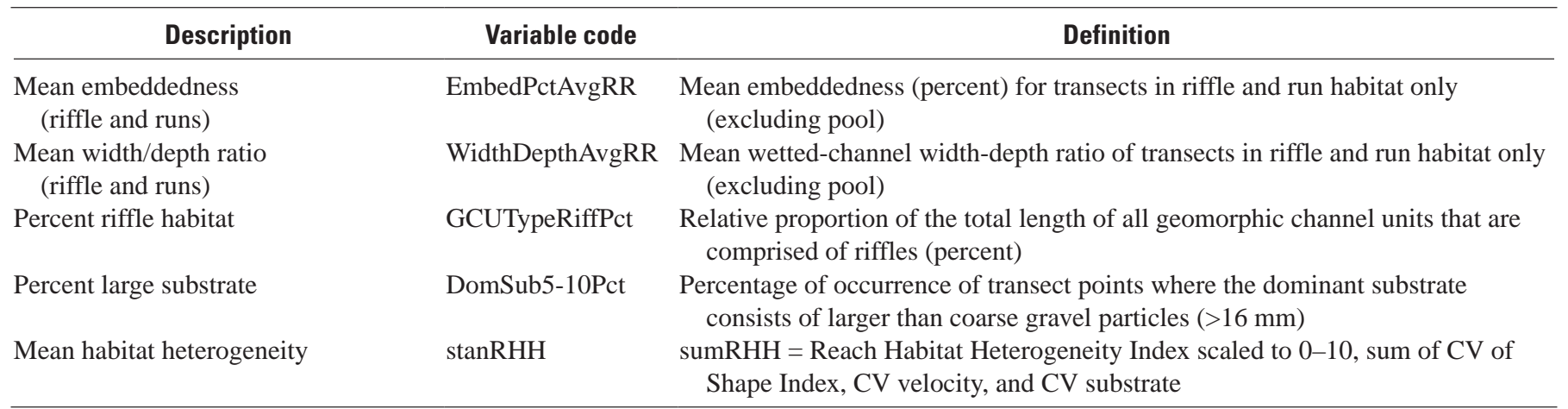

Table A5. Hydrologic variation metrics.

[Abbreviations: POR, period of record. Symbols: >, greater than; $\geq$, greater than or equal to]

\begin{tabular}{|c|c|c|}
\hline Description & Variable code & Definition \\
\hline $\begin{array}{l}\text { Number of falling events }>9 \times \text { median } \\
\quad \text { (PeriodF9) }\end{array}$ & d_periodf9 & $\begin{array}{l}\text { Frequency of falling stream-discharge events, where hourly stream-discharge } \\
\text { change is } \geq 9 \text { multiplied by the median fall over POR (number of hourly } \\
\text { periods) }\end{array}$ \\
\hline $\begin{array}{l}\text { Richards-Baker Flashiness Index } \\
\text { (Rb-flash) }\end{array}$ & d_rb_flash & $\begin{array}{l}\text { Version of Richards-Baker Flashiness Index (Baker and others, 2004), } \\
\text { calculated as the sum of the absolute value of the relative change in daily } \\
\text { mean stream discharge, divided by the sum of the daily mean stream } \\
\text { discharge for the POR (dimensionless) }\end{array}$ \\
\hline
\end{tabular}


Table A6. Stream temperature metrics.

[Abbreviation: ODEQ, Oregon Department of Environmental Quality]

\begin{tabular}{|c|c|c|}
\hline Description & Variable code & Definition \\
\hline $\begin{array}{l}\text { Minimum temperature } \\
\text { (95th percentile) }\end{array}$ & t_pct_95n & $\begin{array}{l}\text { 95th-percentile stream-temperature value over period of record, divided by median stream- } \\
\text { temperature value over period of record (dimensionless) }\end{array}$ \\
\hline
\end{tabular}

Table A7. Water-chemistry variables.

[Abbreviations: DO, dissolved oxygen; N, nitrogen; P, phosphorus; SPMD, semipermeable membrane device; AFDM, ash-free dry mass; TEQ, toxic equivalent; $\mathrm{mg} / \mathrm{L}$, milligram per liter; $\mathrm{mg} / \mathrm{m}^{2}$, milligram per square meter; $\mu \mathrm{S} / \mathrm{cm}$, microsiemens per centimeter at $25 \mathrm{degrees}$ Celsius; g/mi² , gram per square meter]

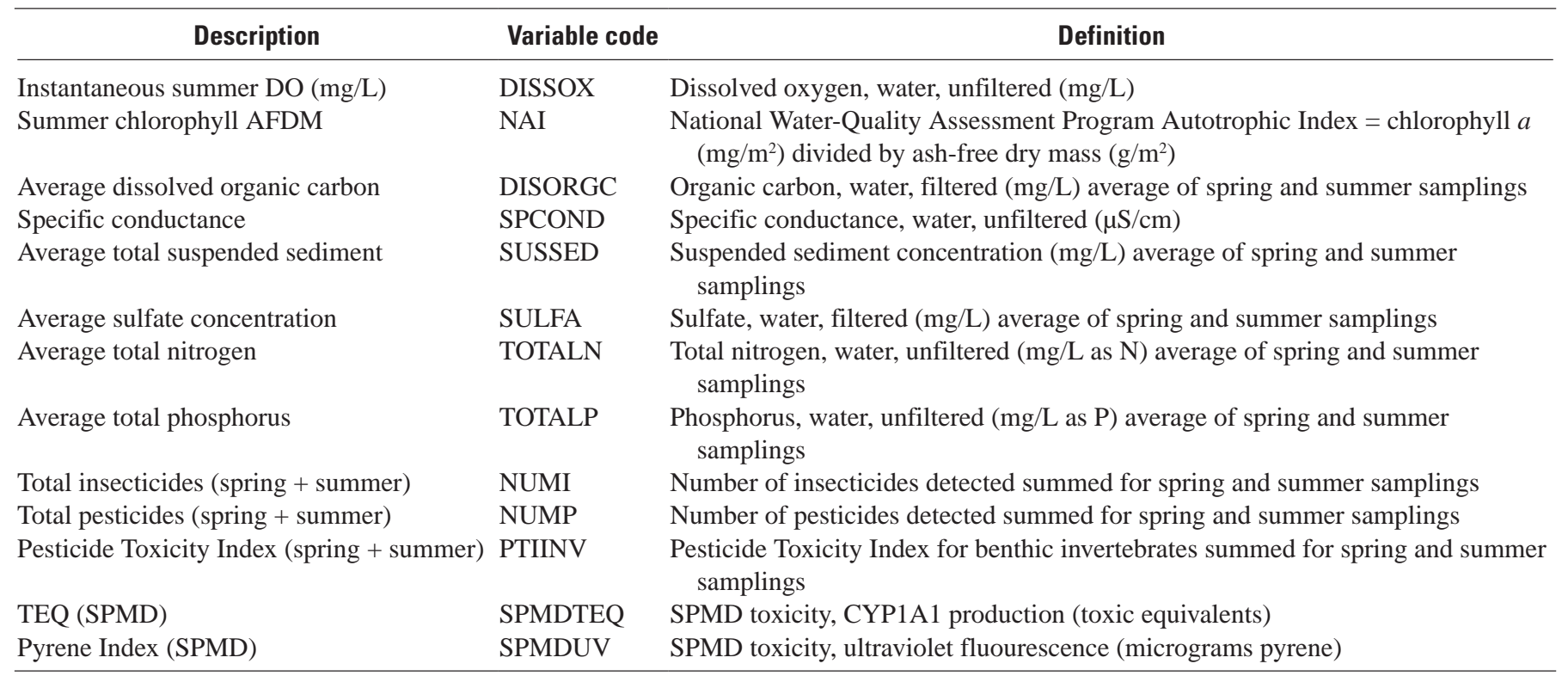

Table A8. Invertebrate variables.

[Abbreviations: EPT, ephemeroptera, plecoptera, trichoptera (mayflies, stonefiles, caddisflies); EPEM, Ephemeropera; USEPA, U.S. Environmental Protection Agency; PLECO, Plecoptera; nMDS, non-metric dimensional scaling an ordination technique]

\begin{tabular}{lll}
\hline \multicolumn{1}{c}{ Description } & Variable code & \\
\hline EPEM abundance & EPEM & Abundance of mayflies \\
EPEM richness & EPEMR & Richness composed of mayflies \\
EPT/chironomid ratio & EPT_CHR & Ratio of EPT richness to midge richness \\
EPT richness & EPTR & Richness composed of mayflies, stoneflies, and caddisflies \\
PLECO percent & PLECOp & Percentage of total abundance composed of stoneflies \\
PLECO richness & PLECOR & Richness composed of stoneflies \\
Other diptera percent richness & ODIPNIRp & Percentage of total richness composed of non-midge Diptera and non-insects \\
Intolerant abundance & Intol_abund & Abundance-weighted USEPA tolerance value for intolerant taxa \\
Tolerant richness & RICHTOL & Average USEPA tolerance values for sample based on richness \\
Tolerant percent richness & RICHTOLp & Average USEPA tolerance values for sample based on percent richness \\
Tolerant abundance & ABUNDTOL & Abundence-weighted USEPA tolerance value for sample \\
Amphipod percent & AMPHIp & Percentage of total abundance composed of Amphipoda \\
Noninsect percent richness & NONINSRp & Percentage of total richness composed of noninsects \\
Oligochaet percent richness & OLOGORp & Percentage of total richness composed of Oligochaeta \\
nMDS Axis1 score & nMDS axis 1 & Axis 1 values from a bi-plot of 2-dimensional distribution based on multivariate similarities \\
\hline
\end{tabular}


Table A9. List of algal taxa identified in Richest Target Habitat samples, Willamette River basin and surrounding area, Oregon and Washington.

[Algal taxa from 28 Richest Targeted Habitat (RTH) samples. Abbreviations: $\mathrm{cm}^{2}$, square centimeter; $\mu \mathrm{m}^{3} / \mathrm{cm}^{2}$, cubic micron per square centimeter; sp., species; var., variety; D, diatom; BG, blue-green algae; G, green algae; E, euglenophyte; R, red algae; aff., affinis (similar to); cf., confer (compare with)]

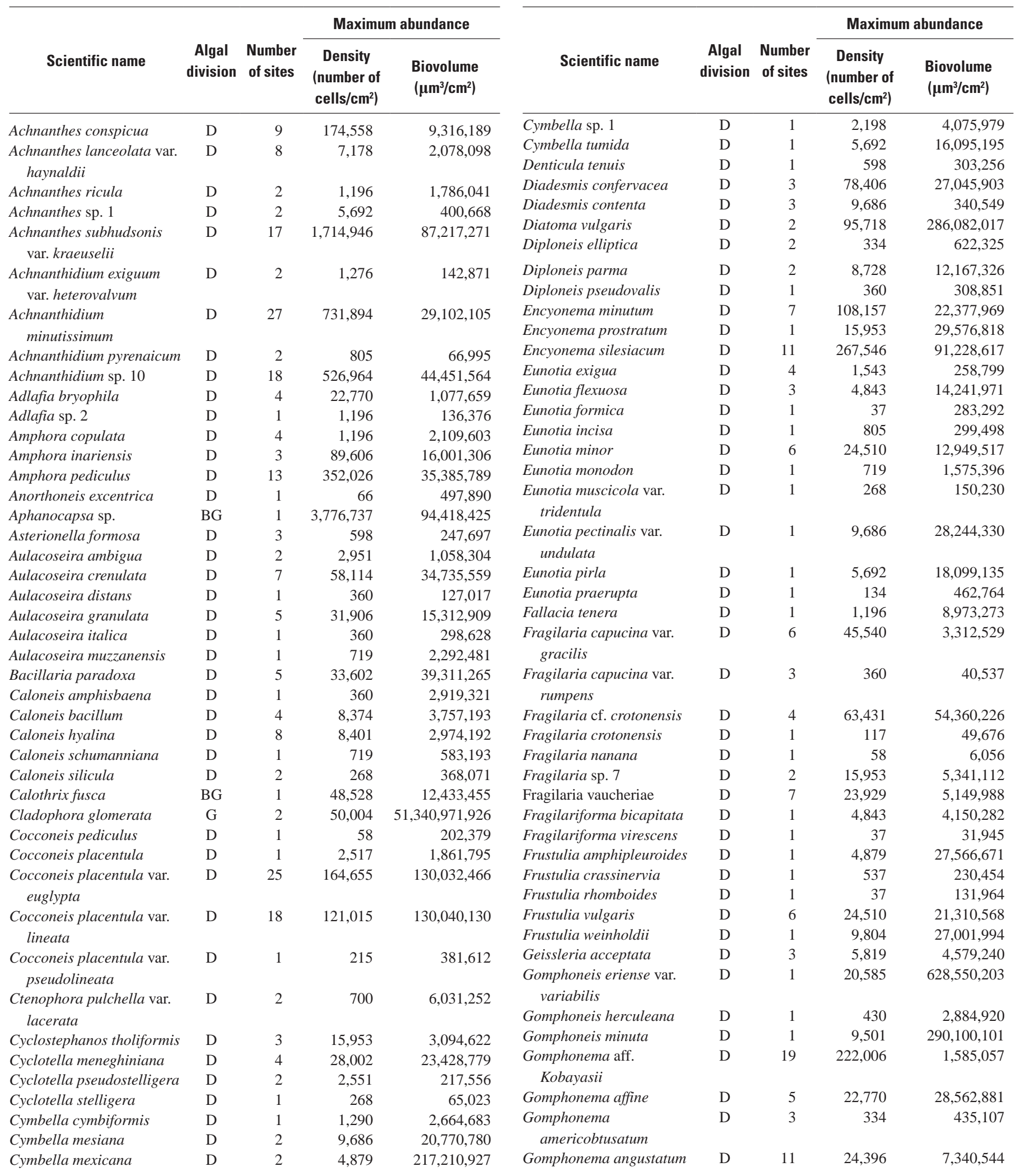


Table A9. List of algal taxa identified in Richest Target Habitat samples, Willamette River basin and surrounding area, Oregon and Washington.-Continued

[Algal taxa from 28 Richest Targeted Habitat (RTH) samples. Abbreviations: $\mathrm{cm}^{2}$, square centimeter; $\mu \mathrm{m}^{3} / \mathrm{cm}^{2}$, cubic micron per square centimeter; sp., species; var., variety; D, diatom; BG, blue-green algae; G, green algae; E, euglenophyte; R, red algae; aff., affinis (similar to); cf., confer (compare with)]

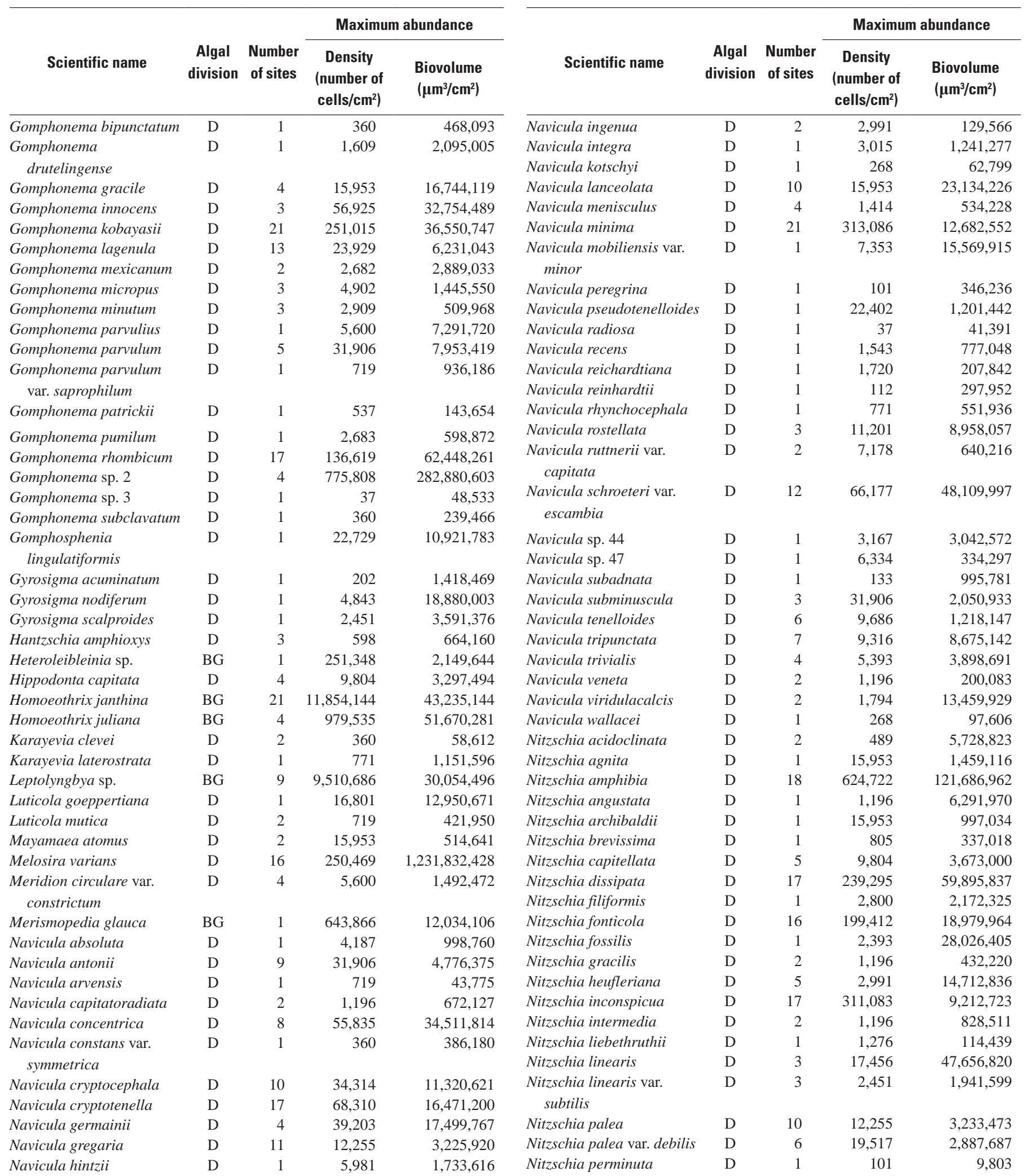


Table A9. List of algal taxa identified in Richest Target Habitat samples, Willamette River basin and surrounding area, Oregon and Washington.-Continued

[Algal taxa from 28 Richest Targeted Habitat (RTH) samples. Abbreviations: $\mathrm{cm}^{2}$, square centimeter; $\mu \mathrm{m}^{3} / \mathrm{cm}^{2}$, cubic micron per square centimeter; sp., species; var., variety; D, diatom; BG, blue-green algae; G, green algae; E, euglenophyte; R, red algae; aff., affinis (similar to); cf., confer (compare with)]

\begin{tabular}{|c|c|c|c|c|c|c|c|c|c|}
\hline \multirow[b]{2}{*}{ Scientific name } & \multirow[b]{2}{*}{$\begin{array}{c}\text { Algal } \\
\text { division }\end{array}$} & \multirow[b]{2}{*}{$\begin{array}{l}\text { Number } \\
\text { of sites }\end{array}$} & \multicolumn{2}{|c|}{ Maximum abundance } & \multirow[b]{2}{*}{ Scientific name } & \multirow[b]{2}{*}{$\begin{array}{c}\text { Algal } \\
\text { division }\end{array}$} & \multirow[b]{2}{*}{$\begin{array}{l}\text { Number } \\
\text { of sites }\end{array}$} & \multicolumn{2}{|c|}{ Maximum abundance } \\
\hline & & & $\begin{array}{c}\text { Density } \\
\text { (number of } \\
\text { cells } / \mathrm{cm}^{2} \text { ) }\end{array}$ & $\begin{array}{c}\text { Biovolume } \\
\left(\mu \mathrm{m}^{3} / \mathrm{cm}^{2}\right)\end{array}$ & & & & $\begin{array}{c}\text { Density } \\
\text { (number of } \\
\text { cells } / \mathrm{cm}^{2} \text { ) }\end{array}$ & $\begin{array}{c}\text { Biovolume } \\
\left(\mu \mathrm{m}^{3} / \mathrm{cm}^{2}\right)\end{array}$ \\
\hline Nitzschia radicula & $\mathrm{D}$ & 1 & 9,686 & $113,457,180$ & Sellaphora seminulum & $\mathrm{D}$ & 21 & 143,577 & $486,913,494$ \\
\hline Nitzschia recta & $\mathrm{D}$ & 7 & 15,953 & $28,511,891$ & Simonsenia delognei & $\mathrm{D}$ & 4 & 8,728 & 456,124 \\
\hline Nitzschia sigmoidea & $\mathrm{D}$ & 13 & 24,214 & $64,554,667$ & Spirogyra sp. & G & 1 & 10,016 & $808,152,137$ \\
\hline Nitzschia sociabilis & $\mathrm{D}$ & 6 & 39,216 & $8,558,069$ & Stauroneis kriegeri & $\mathrm{D}$ & 4 & 805 & 124,252 \\
\hline Nitzschia solita & $\mathrm{D}$ & 1 & 5,600 & $1,066,901$ & Stauroneis phoenicenteron & $\mathrm{D}$ & 1 & 207 & $11,516,940$ \\
\hline Nitzschia tubicola & $\mathrm{D}$ & 1 & 1,276 & 288,948 & Staurosira construens & $\mathrm{D}$ & 2 & 11,385 & $2,379,854$ \\
\hline Nitzschia vermicularis & $\mathrm{D}$ & 1 & 11,201 & $51,243,212$ & Staurosira construens var. & $\mathrm{D}$ & 2 & 137,210 & $68,470,231$ \\
\hline Nupela silvahercynia & $\mathrm{D}$ & 2 & 16,198 & $121,500,890$ & binodis & & & & \\
\hline Nupela sp. 1 & $\mathrm{D}$ & 3 & 202,089 & $2,241,256$ & Staurosira construens var. & $\mathrm{D}$ & 1 & 11,201 & $3,170,875$ \\
\hline Nupela wellneri & $\mathrm{D}$ & 1 & 1,196 & $8,973,273$ & subsalina & & & & \\
\hline Oedogonium sp. & $\mathrm{G}$ & 6 & 56,756 & $1,132,047,129$ & Staurosira construens var. & $\mathrm{D}$ & 4 & 106,542 & $9,569,688$ \\
\hline Oscillatoria princeps & $\mathrm{BG}$ & 1 & $4,897,853$ & $358,250,872$ & venter & & & & \\
\hline Pandorina morum & $\mathrm{G}$ & 1 & 32,885 & $2,795,192$ & Staurosira elliptica & $\mathrm{D}$ & 1 & 117 & 5,501 \\
\hline Parlibellus protracta & $\mathrm{D}$ & 1 & 37 & 33,772 & Staurosirella pinnata & $\mathrm{D}$ & 1 & 62,956 & $10,134,217$ \\
\hline Phormidium autumnale & BG & 16 & $4,011,385$ & $188,628,500$ & Stephanodiscus hantzschii & $\mathrm{D}$ & 1 & 360 & 115,171 \\
\hline Phormidium retzii & $\mathrm{BG}$ & 3 & 150,011 & $22,207,813$ & Stephanodiscus minutulus & $\mathrm{D}$ & 1 & 202 & 58,697 \\
\hline Pinnularia divergens & $\mathrm{D}$ & 4 & 207 & $1,552,878$ & Stigeoclonium lubricum & $\mathrm{G}$ & 1 & 213,468 & $84,043,977$ \\
\hline Pinnularia microstauron & $\mathrm{D}$ & 4 & 4,902 & $5,905,940$ & Surirella amphioxys & $\mathrm{D}$ & 1 & 360 & $384,625,288$ \\
\hline Pinnularia sudetica & $\mathrm{D}$ & 1 & 638 & $2,370,394$ & Surirella angusta & $\mathrm{D}$ & 6 & 5,600 & $6,141,920$ \\
\hline Pinnularia viridis & $\mathrm{D}$ & 1 & 1,079 & $5,906,620$ & Surirella biseriata & $\mathrm{D}$ & 2 & 5,600 & $89,695,680$ \\
\hline Placoneis elginensis & $\mathrm{D}$ & 1 & 1,438 & 759,305 & Surirella brebissonii var. & $\mathrm{D}$ & 4 & 11,637 & $11,901,456$ \\
\hline Planothidium delicatulum & $\mathrm{D}$ & 1 & 1,196 & 368,248 & kuetzingii & & & & \\
\hline Planothidium & $\mathrm{D}$ & 20 & 86,806 & $6,694,362$ & Synedra acus & $\mathrm{D}$ & 2 & 2,909 & $4,921,361$ \\
\hline frequentissimum & & & & & Synedra parasitica & $\mathrm{D}$ & 6 & 52,367 & $4,721,265$ \\
\hline Planothidium lanceolatum & $\mathrm{D}$ & 22 & 215,365 & $53,446,394$ & Synedra parasitica var. & $\mathrm{D}$ & 2 & 1,276 & 126,279 \\
\hline Planothidium rostratum & $\mathrm{D}$ & 7 & 4,843 & 576,598 & subconstricta & & & & \\
\hline Porphyrosiphon luteus & BG & 1 & $1,029,009$ & $25,725,232$ & Synedra ulna & $\mathrm{D}$ & 16 & 22,402 & $124,196,962$ \\
\hline Porphyrosiphon & $\mathrm{BG}$ & 6 & $3,316,956$ & $357,276,740$ & Tabellaria flocculosa & $\mathrm{D}$ & 1 & 268 & 121,629 \\
\hline martensianus & & & & & Thalassiosira pseudonana & $\mathrm{D}$ & 3 & 15,953 & 763,341 \\
\hline Psammothidium & $\mathrm{D}$ & 1 & 5,819 & $8,687,172$ & Trachelomonas volvocina & $\mathrm{E}$ & 2 & 5,930 & $8,715,732$ \\
\hline lauenburgianum & & & & & Tryblionella apiculata & $\mathrm{D}$ & 2 & 5,600 & $2,114,415$ \\
\hline Pseudanabaena sp. & BG & 8 & 533,669 & $1,387,073$ & Tryblionella calida & $\mathrm{D}$ & 2 & 5,600 & $6,062,124$ \\
\hline Reimeria sinuata & $\mathrm{D}$ & 18 & 91,080 & $15,338,294$ & Tryblionella debilis & $\mathrm{D}$ & 1 & 4,902 & $1,807,780$ \\
\hline Rhoicosphenia abbreviata & $\mathrm{D}$ & 25 & 726,420 & $307,435,607$ & Tryblionella victoriae & $\mathrm{D}$ & 1 & 268 & $3,142,500$ \\
\hline Rhopalodia gibba & $\mathrm{D}$ & 1 & 1,196 & $7,244,122$ & Unknown Cyanophyte & BG & 8 & 113,512 & $143,431,520$ \\
\hline Scenedesmus acutus & $\mathrm{G}$ & 1 & 13,354 & 432,707 & (colonial coccoid) & & & & \\
\hline Scenedesmus denticulatus & $\mathrm{G}$ & 1 & 49,219 & $1,000,115$ & Unknown Cyanophyte & BG & 1 & $6,180,652$ & $2,697,679,030$ \\
\hline Scenedesmus ecornis & $\mathrm{G}$ & 2 & 30,002 & 744,477 & (colonial coccoid) & & & & \\
\hline Scenedesmus quadricauda & $\mathrm{G}$ & 2 & 30,002 & 988,363 & Unknown Rhodophyte & $\mathrm{R}$ & 25 & $2,442,559$ & $1,174,999,542$ \\
\hline Sellaphora laevissima & $\mathrm{D}$ & 2 & 805 & 895,327 & Florideophycidae & & & & \\
\hline Sellaphora pupula & $\mathrm{D}$ & 8 & 16,801 & $7,770,995$ & (chantransia) & & & & \\
\hline
\end{tabular}


Table A10. Macroinvertebrate species list sorted alphabetically by scientific name, order, number of sites collected (richest target habitat samples) and maxmum abundance among all 28 sites, Willamette River basin and surrounding area, Oregon and Washington.

[Abbreviation: sp., species]

\begin{tabular}{|c|c|c|c|c|c|c|c|}
\hline Scientific name & Order & $\begin{array}{l}\text { Number } \\
\text { of sites }\end{array}$ & $\begin{array}{l}\text { Maximum } \\
\text { abundance }\end{array}$ & Scientific name & Order & $\begin{array}{l}\text { Number } \\
\text { of sites }\end{array}$ & $\begin{array}{c}\text { Maximum } \\
\text { abundance }\end{array}$ \\
\hline Ablabesmyia sp. & Diptera & 1 & 41 & Gomphidae & Odonata & 2 & 113 \\
\hline Acentrella turbida & Ephemeroptera & 8 & 1,455 & Hesperoperla pacifica & Plecoptera & 9 & 94 \\
\hline Ampumixis dispar & Coleoptera & 1 & 54 & Heterlimnius sp. & Coleoptera & 1 & 17 \\
\hline Anisogammarus sp. & Amphipoda & 4 & 536 & Hexatoma sp. & Diptera & 1 & 32 \\
\hline Arctopsyche grandis & Trichoptera & 1 & 1 & Hydropsyche sp. & Trichoptera & 2 & 211 \\
\hline Argia sp. & Odonata & 5 & 90 & Hydroptila sp. & Trichoptera & 3 & 61 \\
\hline Atherix pachypus & Diptera & 1 & 16 & Ironodes sp. & Ephemeroptera & 4 & 145 \\
\hline Baetis tricaudatus & Ephemeroptera & 23 & 3,082 & Juga sp. & Mesogastropoda & 25 & 3,870 \\
\hline Brillia sp. & Diptera & 11 & 86 & Lara sp. & Coleoptera & 9 & 147 \\
\hline Capniidae & Plecoptera & 1 & 31 & Limnophyes sp. & Diptera & 4 & 121 \\
\hline Cardiocladius sp. & Diptera & 2 & 260 & Lumbriculidae & Lumbriculida & 20 & 581 \\
\hline Ceratopogonidae & Diptera & 1 & 54 & Malenka sp. & Plecoptera & 6 & 134 \\
\hline Ceratopsyche cockerelli & Trichoptera & 14 & 2,904 & Margaritifera falcata & Paleoheterodonta & 4 & 2 \\
\hline Chelifera/Metachela sp. & Diptera & 3 & 141 & Megadrile & Class Oligochaeta & 12 & 194 \\
\hline Cheumatopsyche sp. & Trichoptera & 19 & 3,467 & Menetus sp. & Basommatophora & 5 & 107 \\
\hline Chironomus sp. & Diptera & 1 & 64 & Micrasema sp. & Trichoptera & 4 & 134 \\
\hline Cleptelmis addenda & Coleoptera & 5 & 323 & Micropsectra sp. & Diptera & 8 & 311 \\
\hline Collembola & Collembola & 2 & 32 & Micropsectra/Tanytarsus & Diptera & 13 & 933 \\
\hline Corbicula sp. & Veneroida & 3 & 282 & sp. & & & \\
\hline Corynoneura sp. & Diptera & 4 & 30 & Microtendipes sp. & Diptera & 2 & 15 \\
\hline Dicosmoecus gilvipes & Trichoptera & 5 & 57 & Ordobrevia nubifera & Coleoptera & 2 & 97 \\
\hline Dicranota sp. & Diptera & 2 & 27 & Pacifastacus leniusculus & Decapoda & 15 & 20 \\
\hline Dicrotendipes sp. & Diptera & 3 & 153 & Parakiefferiella sp. & Diptera & 1 & 11 \\
\hline Diphetor hageni & Ephemeroptera & 6 & 56 & Paraleptophlebia sp. & Ephemeroptera & 19 & 672 \\
\hline Diplocladius cultriger & Diptera & 2 & 387 & Paramerina sp. & Diptera & 2 & 22 \\
\hline Dixa sp. & Diptera & 1 & 32 & Parametriocnemus sp. & Diptera & 13 & 671 \\
\hline Drunella doddsi & Ephemeroptera & 4 & 257 & Paraphaenocladius sp. & Diptera & 1 & 13 \\
\hline Drunella grandis & Ephemeroptera & 1 & 65 & Paratanytarsus sp. & Diptera & 9 & 541 \\
\hline Enchytraeidae & Enchytraeida & 2 & 371 & Pericoma/Telmatoscopus & Diptera & 1 & 27 \\
\hline Epeorus sp. & Ephemeroptera & 1 & 556 & sp. & & & \\
\hline Ephemerella sp. & Ephemeroptera & 1 & 23 & Perlinodes aureus & Plecoptera & 1 & 270 \\
\hline Eukiefferiella sp. & Diptera & 16 & 864 & Phaenopsectra sp. & Diptera & 5 & 130 \\
\hline Eukiefferiella/Tvetenia & Diptera & 1 & 23 & Physa sp. & Basommatophora & 5 & 82 \\
\hline sp. & & & & Pisidium sp. & Veneroida & 12 & 222 \\
\hline Ferrissia sp. & Basommatophora & 16 & 790 & Polypedilum sp. & Diptera & 19 & 307 \\
\hline Fluminicola sp. & Mesogastropoda & 15 & 11,419 & Porifera & Phylum & 1 & 6 \\
\hline Glossosoma sp. & Trichoptera & 5 & 484 & Prostoma sp. & Hoplonemertea & 9 & 40 \\
\hline Glyptotendipes sp. & Diptera & 1 & 64 & Psephenus falli & Coleoptera & 1 & 1,322 \\
\hline
\end{tabular}


Table A10. Macroinvertebrate species list sorted alphabetically by scientific name, order, number of sites collected (richest target habitat samples) and maximum abundance among all 28 sites, Willamette River basin and surrounding area, Oregon and Washington.Continued

[Abbreviation: sp., species]

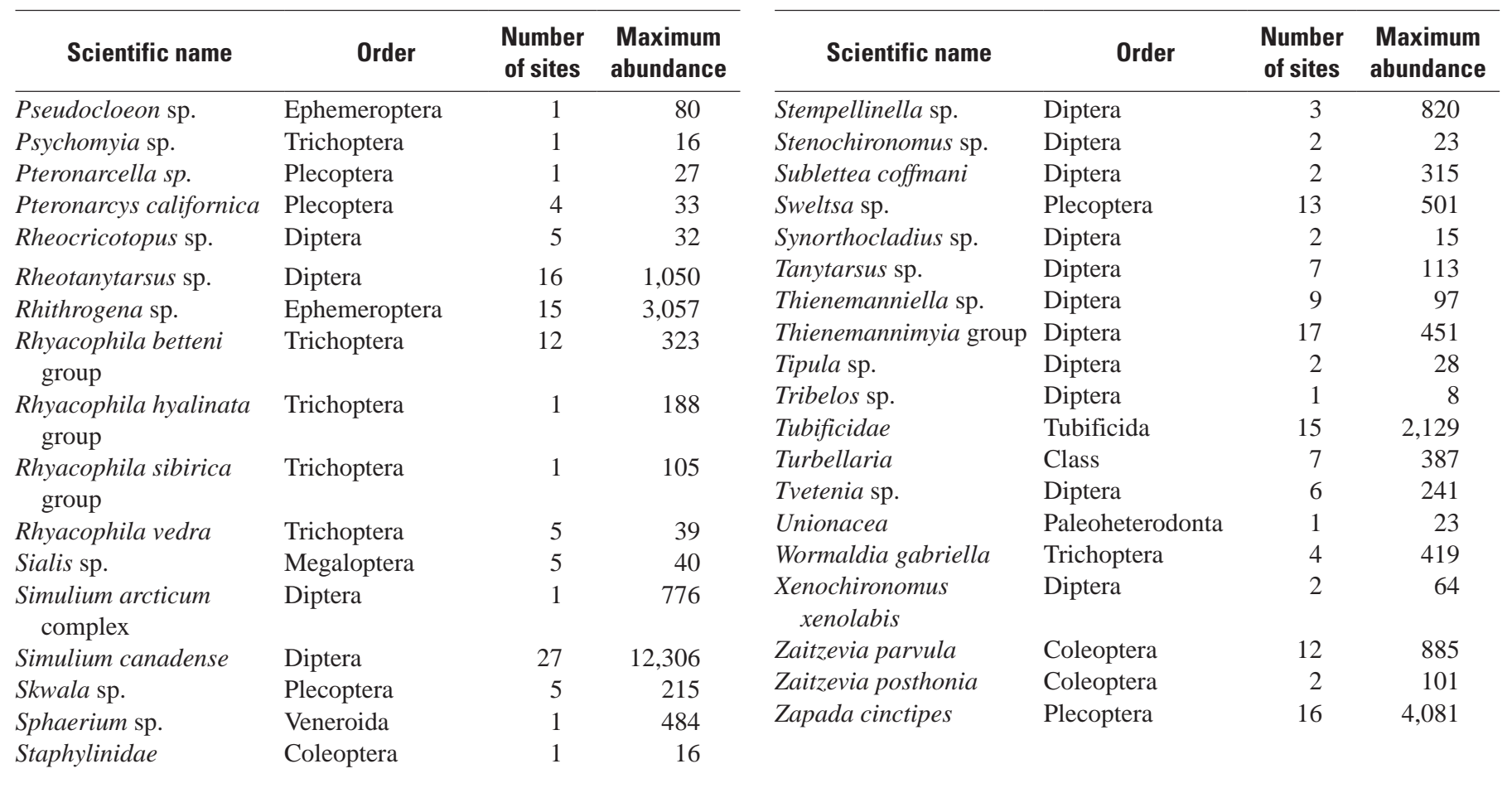


Table A11. Fish species list sorted by Order, Family, and scientific name, fish common name, native or nonnative species, number of sites collected and maximum abundance among all 28 sites, Willamette River basin and surrounding area, Oregon and Washington.

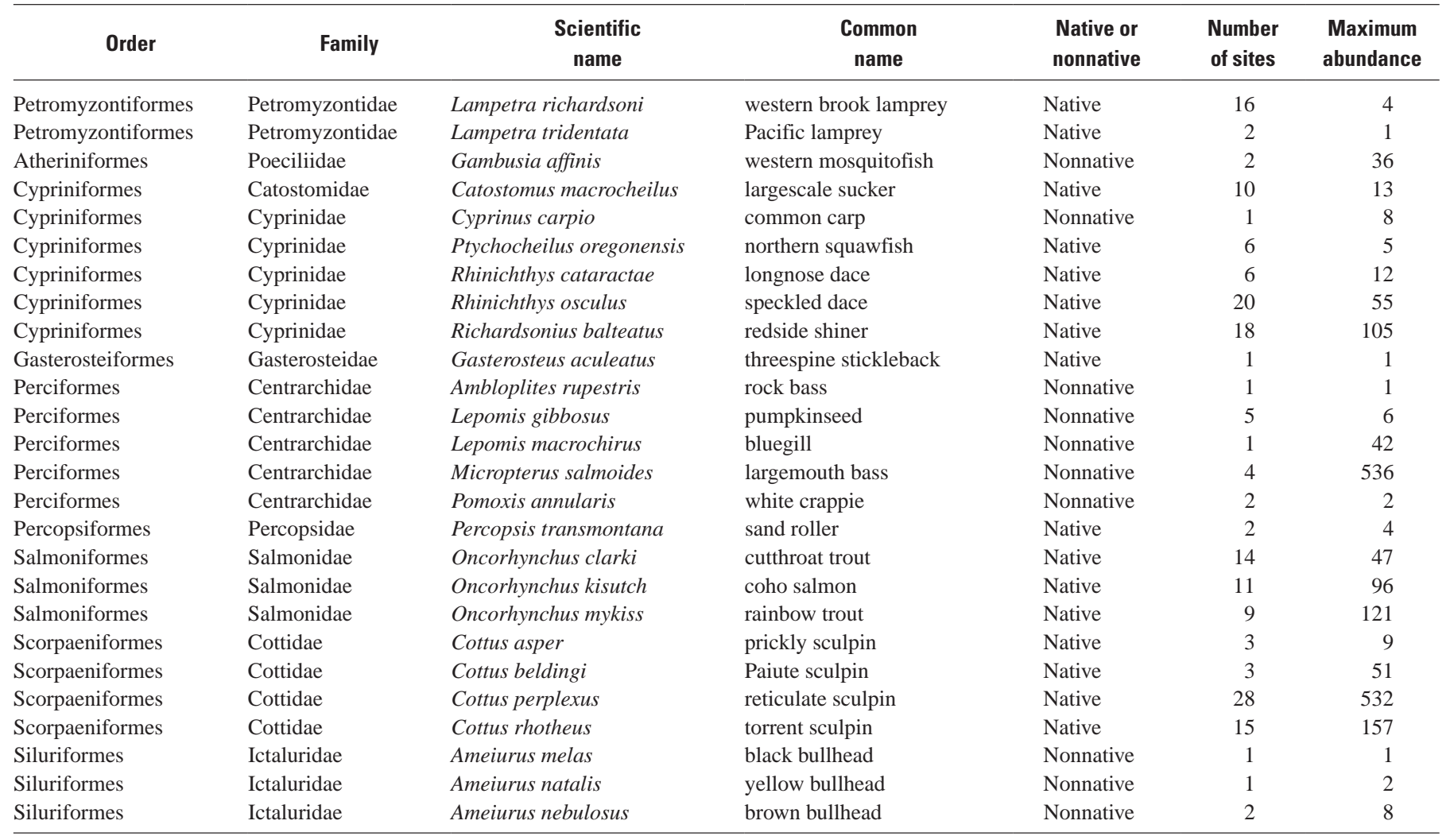


Manuscript approved for publication, July 1, 2008

Prepared by the USGS Publishing Network

Bill Gibbs

Bob Crist

Debra Grillo

Bobbie Richey

Sharon Wahlstrom

For more information concerning the research in this report, contact the Director, Oregon Water Science Center

U.S. Geological Survey

2130 SW 5th Avenue

Portland, Oregon 97201

http://oregon.usgs.gov/ 


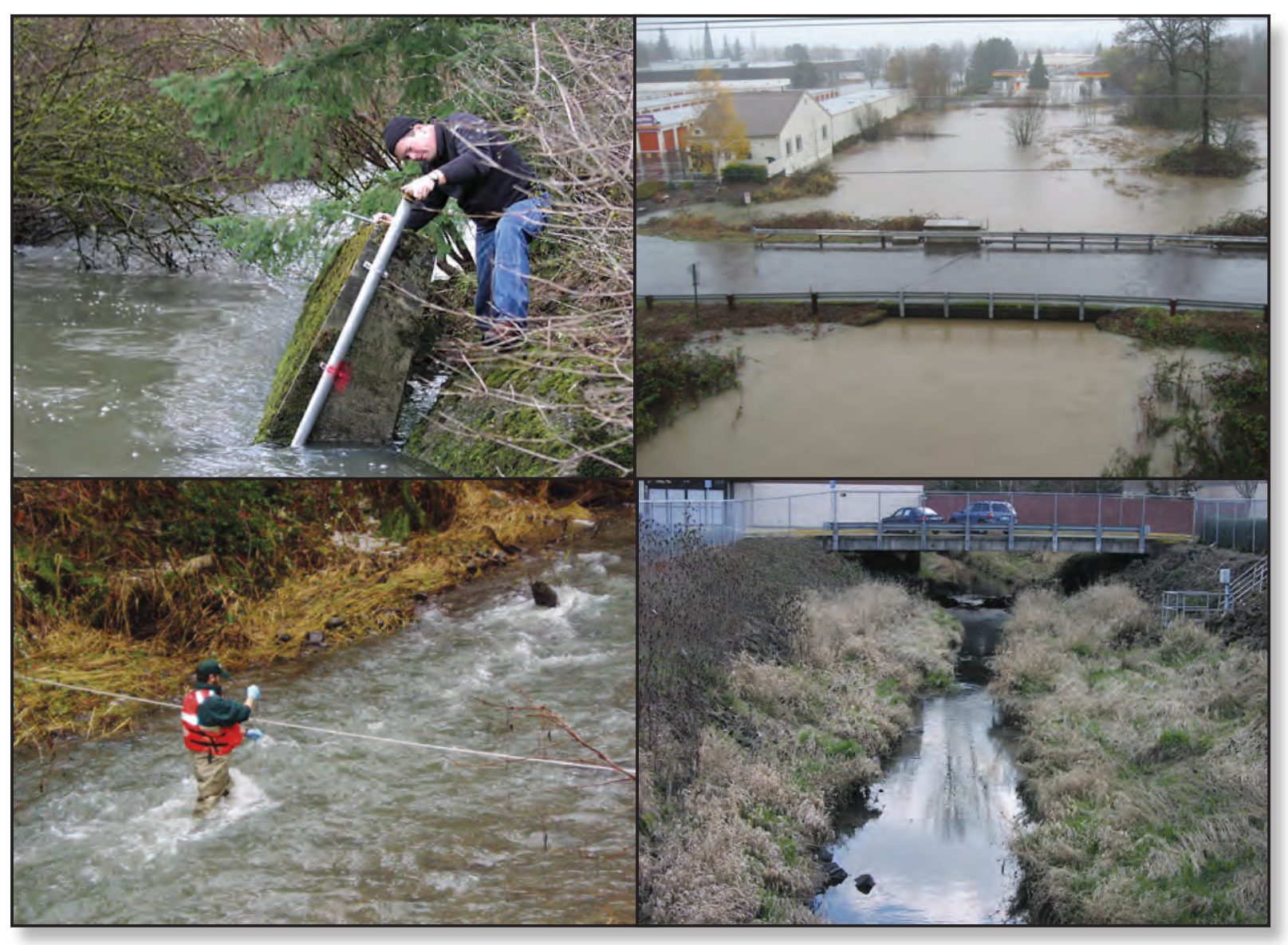

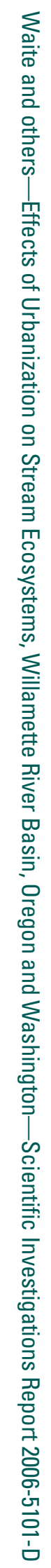

